\title{
Utirik Atoll Dose Assessment
}

William L. Robison

Cynthia L. Conrado

Kenneth T. Bogen

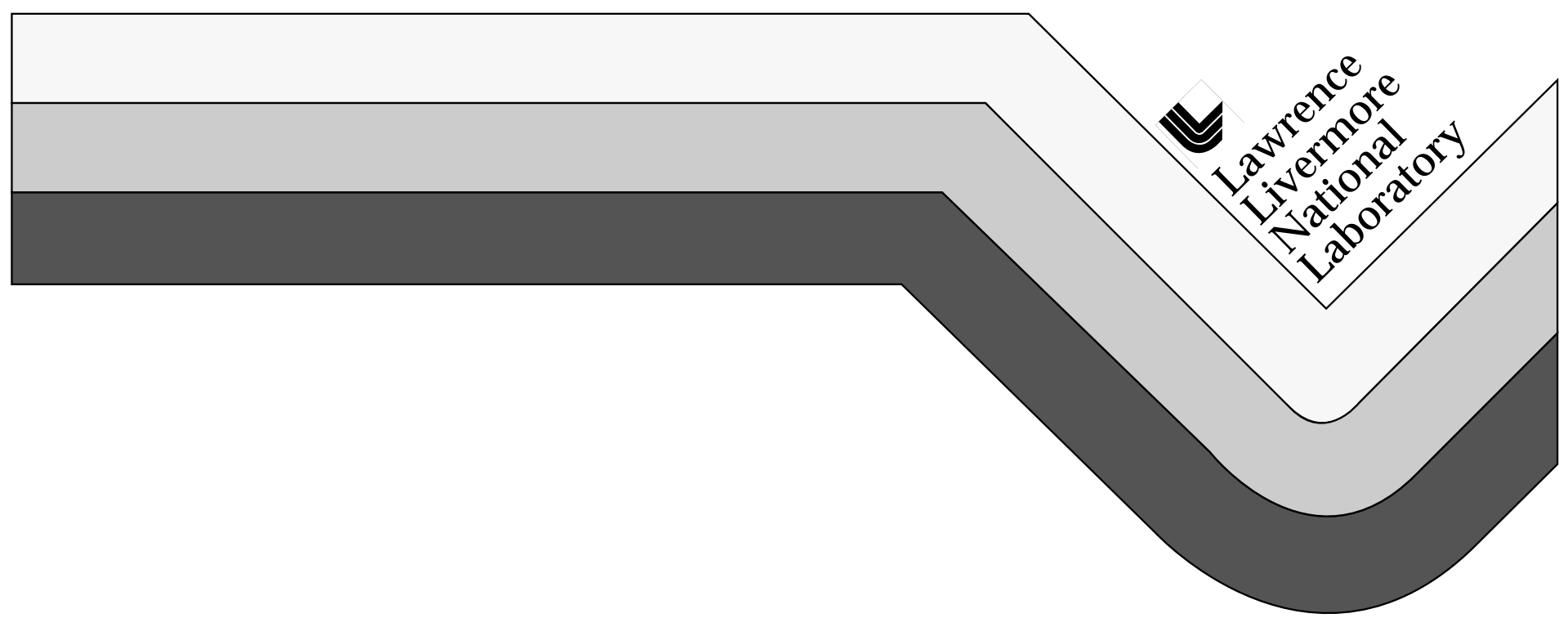




\section{DISCLAIMER}

This document was prepared as an account of work sponsored by an agency of the United States Government. Neither the United States Government nor the University of California nor any of their employees, makes any warranty, express or implied, or assumes any legal liability or responsibility for the accuracy, completeness, or usefulness of any information, apparatus, product, or process disclosed, or represents that its use would not infringe privately owned rights. Reference herein to any specific commercial product, process, or service by trade name, trademark, manufacturer, or otherwise, does not necessarily constitute or imply its endorsement, recommendation, or favoring by the United States Government or the University of California. The views and opinions of authors expressed herein do not necessarily state or reflect those of the United States Government or the University of California, and shall not be used for advertising or product endorsement purposes.

This report has been reproduced directly from the best available copy.

Available to DOE and DOE contractors from the Office of Scientific and Technical Information P.O. Box 62, Oak Ridge, TN 37831

Prices available from (423) 576-8401

Available to the public from the National Technical Information Service

U.S. Department of Commerce

5285 Port Royal Rd.,

Springfield, VA 22161

Work performed under the auspices of the U.S. Department of Energy by Lawrence Livermore National Laboratory under Contract W-7405-ENG-48. 


\title{
Utirik Atoll Dose Assessment
}

\author{
William L. Robison \\ Cynthia L. Conrado
}

Kenneth T. Bogen

Manuscript date: October 1999 



\section{Table of Contents}

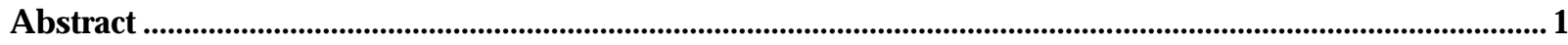

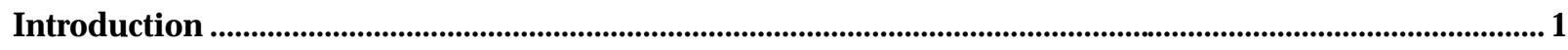

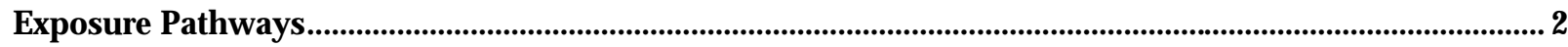

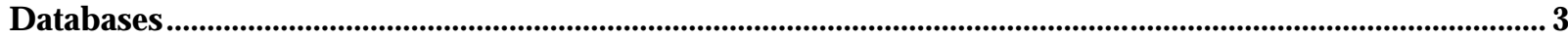

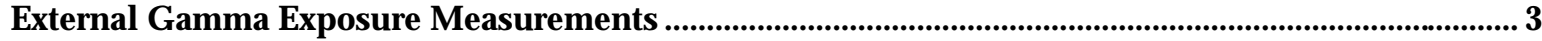

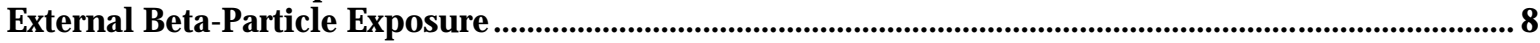

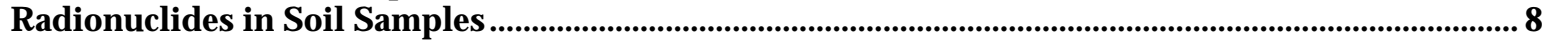

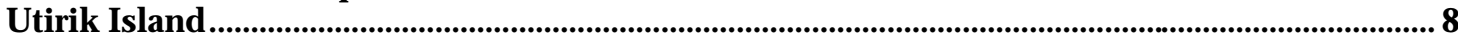

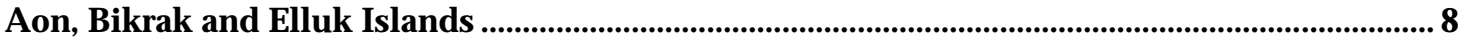

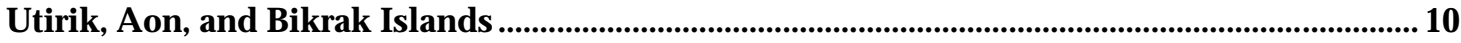

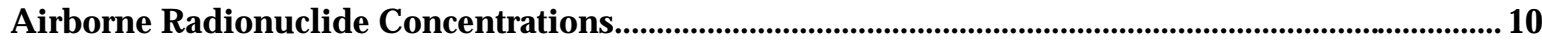

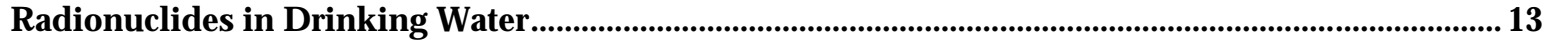

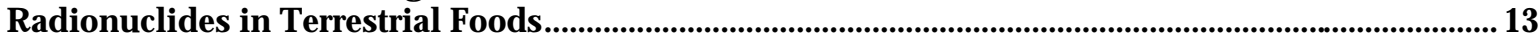

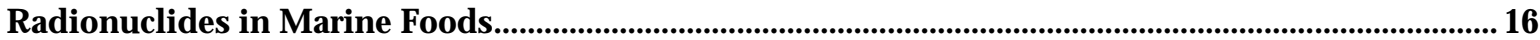

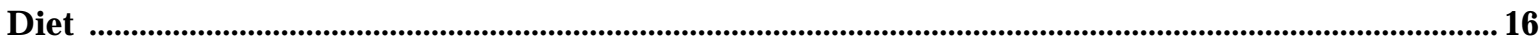

Terrestrial and Marine Food Consumption .......................................................................................... 16

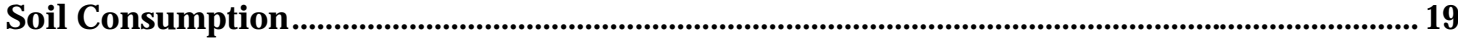

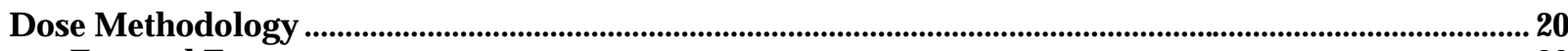

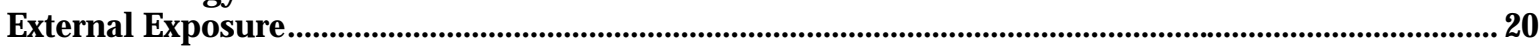

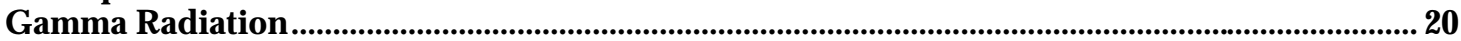

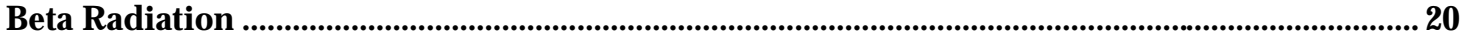

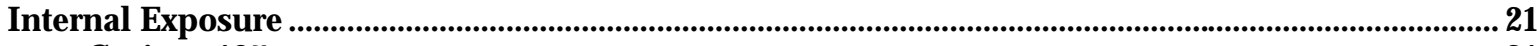

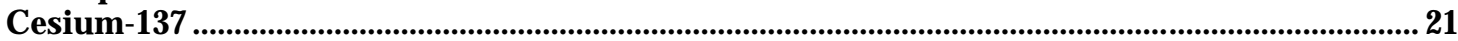

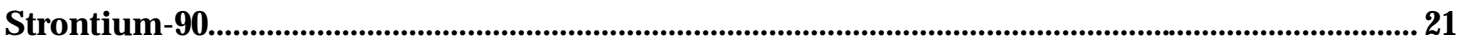

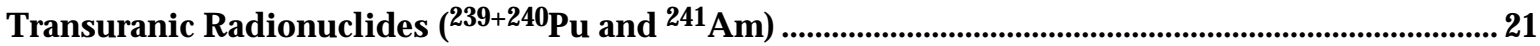

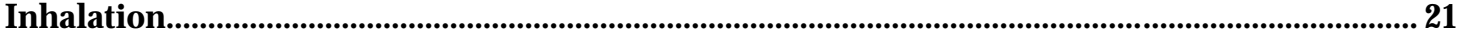

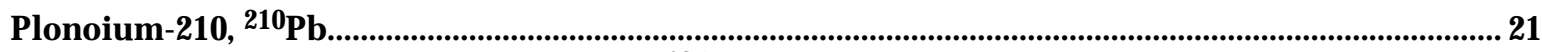

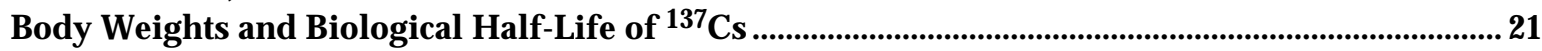

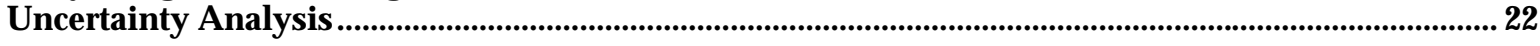

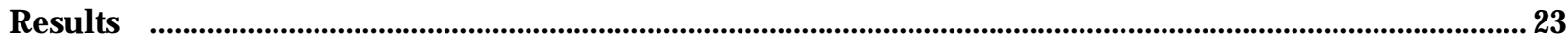

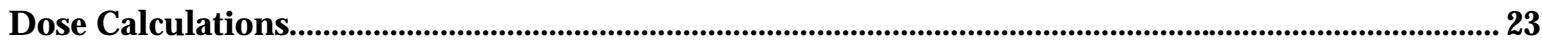

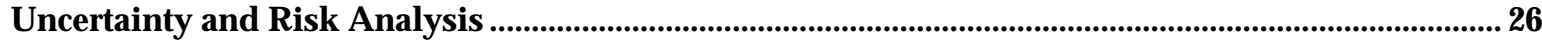

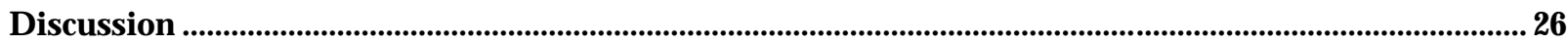

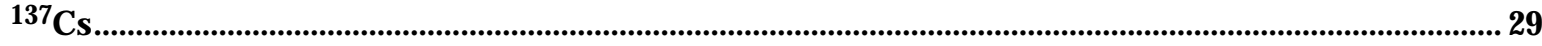

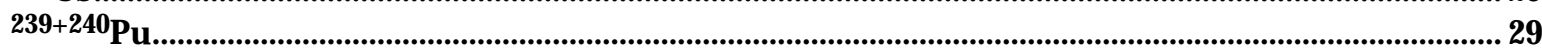

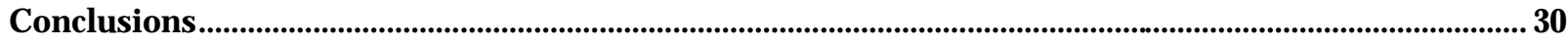

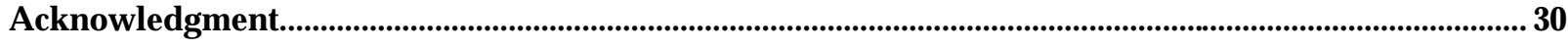

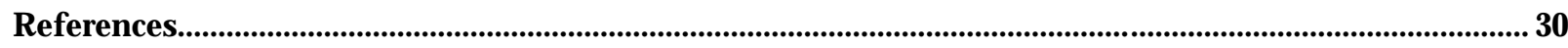

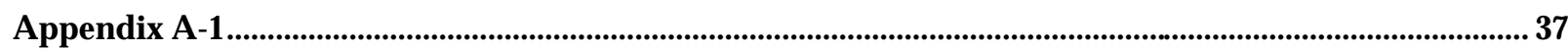

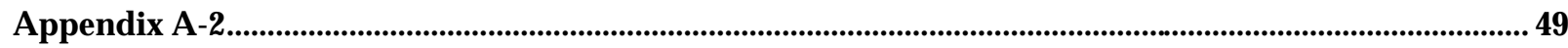

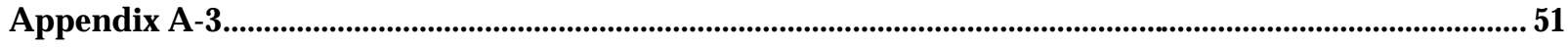

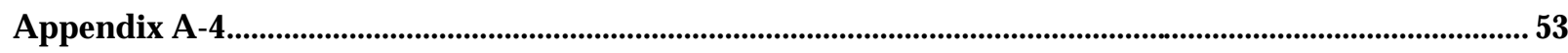

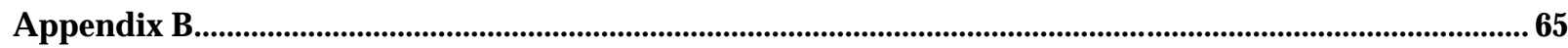

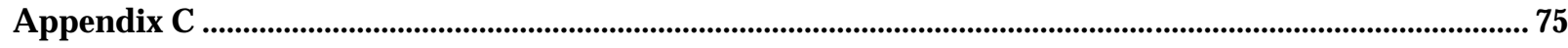

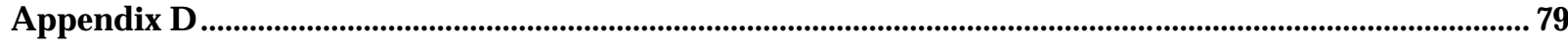




\section{List of Tables}

Table 1. Marshall Islands background dose.

Table 2. External gamma exposure at Utirik Atoll. 4

Table 3. Cesium-137 and ${ }^{241} \mathrm{Am}$ concentration in soil in the interior and village area of Utirik Atoll.

Table 4. The median ${ }^{137} \mathrm{Cs}$ concentration with depth in the soil column at four islands of Utirik Atoll.

Table 5. Resuspension data for high and low resuspension conditions on Bikini and Enewetak Atolls $\left({ }^{239+240} \mathrm{Pu}\right)$.

Table 6. The radionuclide concentrations in foods, water, and surface soil from Utirik Island and the diet model shown as the grams per day intake of each food item.

Table 7. The mean ${ }^{137} \mathrm{Cs}$ concentration in $\mathrm{Bq}^{-1}$ wet weight for Utirik Atoll food produces (decay corrected to 1998).

Table 8. Comparison of the average adult diet model for the Northern Marshall Islands with the average adult diet for the United States.

Table 9. The maximum annual organ equivalent dose and effective dose in $\mathrm{mSv}^{-1}$ for

Utirik Island.

Table 10. The 30-, 50, and 70-y integral effective dose for Utirik Island residents for a diet including imported foods (Imports Available, IA).

Table 11. The 30-, 50-, and 70-y integral effective dose for Utirik Island residents for a diet o only local foods (Imports Unavailable, IUA).

Table 12. The 30-, 50-, and 70-y integral effective dose for each exposure pathway at Utirik Atoll when imported foods are available.

Table 13. Comparison of the 50-y integral dose from weapons-related radionuclides at Utirik Atoll to the $1 \mathrm{mSv}, 0.25 \mathrm{mSv}$, and $0.15 \mathrm{mSv}$ guidelines summed over $50 \mathrm{y}$.

Appendix A-1.1. Cesium-137 radionuclide concentration summary for all soil profiles taken during the 1978 NMIRS and in 1993 on Utirik Island (06I), Utirik Atoll.

Appendix A-1.2. Cesium-137 radionuclide concentration summary for all soil profiles taken in 1993 on Utirik Island (06I), Utirik Atoll.

Appendix A-1.3. Cesium-137 radionuclide concentration summary for all soil profiles taken during the 1978 NMIRS on Utirik Island (06I), Utirik Atoll.

Appendix A-1.4. Cesium-137 radionuclide concentration summary for all soil profiles taken in the village area in 1993 on Utirik Island (06I), Utirik Atoll.

Appendix A-1.5. Cesium-137 radionuclide concentration summary for all soil profiles taken in the interior area in 1993 on Utirik Island (06I), Utirik Atoll. 
Appendix A-1.6. Cesium-137 radionuclide concentration summary for all soil profiles taken during the 1978 NMIRS and in 1994 on Bikrak Island (03I), Utirik Atoll..

Appendix A-1.7. Cesium-137 radionuclide concentration summary for all soil profiles in 1994 on Bikrak Island (03I), Utirik Atoll.

Appendix A-1.8. Cesium-137 radionuclide concentration summary for all soil profiles taken during the 1978 NMIRS on Bikrak Island (03I), Utirik Atoll.

Appendix A-1.9. Cesium-137 radionuclide concentration summary for all soil profiles taken during the 1978 NMIRS and in 1994 on Aon Island (08I), Utirik Atoll.

Appendix A-1.10. Cesium-137 radionuclide concentration summary for all soil profiles taken in 1994 on Aon Island (08I), Utirik Atoll.

Appendix A-1.11. Cesium-137 radionuclide concentration summary for all soil profiles taken during the 1978 NMIRS on Aon Island (08I), Utirik Atoll.

Appendix A-1.12. Cesium-137 radionuclide concentration summary for all soil profiles taken in 1994 on Elluk Island, Utirik Atoll.

Appendix A-2.1. Strontium-90 radionuclide concentration summary for all soil profiles taken during the 1978 NMIRS on Utirik Island (06I), Utirik Atoll.

Appendix A-3.1. Plutonium-239+240 radionuclide concentration summary for all soil profiles taken during the 1978 NMIRS on Utirik Island (06I), Utirik Atoll.

Appendix A-4.1. Americium-241 radionuclide concentration summary for all soil profiles taken during the 1978 NMIRS and in 1993 on Utirik Island (06I), Utirik Atoll.

Appendix A-4.2. Americium-241 radionuclide concentration summary for all soil profiles taken in 1993 on Utirik Island (06I), Utirik Atoll.

Appendix A-4.3. Americium-241 radionuclide concentration summary for all soil profiles taken during the 1978 NMIRS on Utirik Island (06I), Utirik Atoll.

Appendix A-4.4. Americium-241 radionuclide concentration summary for all soil profiles taken in the interior area in 1993 on Utirik Island (06I), Utirik Atoll.

Appendix A-4.5. Americium-241 radionuclide concentration summary for all soil profiles taken in the village area in 1993 on Utirik Island (06I), Utirik Atoll.

Appendix A-4.6. Americium-241 radionuclide concentration summary for all soil profiles taken during the 1978 NMIRS and in 1994 on Bikrak Island (03I), Utirik Atoll.

Appendix A-4.7. Americium-241 radionuclide concentration summary for all soil profiles taken in 1994 on Bikrak Island (03I), Utirik Atoll.

Appendix A-4.8. Americium-241 radionuclide concentration summary for all soil profiles taken during the 1978 NMIRS on Bikrak Island (03I), Utirik Atoll.

Appendix A-4.9. Americium-241 radionuclide concentration summary for all soil profiles taken during the 1978 NMIRS and in 1994 on Aon Island (08I), Utirik Atoll. 
Appendix A-4.10. Americium-241 radionuclide concentration summary for all soil profiles taken in 1994 on Aon Island (08I), Utirik Atoll.

Appendix A-4.11. Americium-241 radionuclide concentration summary for all soil profiles taken during the 1978 NMIRS on Aon Island (08I), Utirik Atoll.

Appendix A-4.12. Americium-241 radionuclide concentration summary for all soil profiles taken in 1994 on Elluk Island (02I), Utirik Atoll. 64

Appendix B-1. Cesium-137 footnotes and references. ............................................................................................... 66

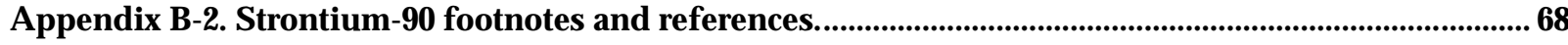

Appendix B-3. Plutonium-239+240 footnotes and references. .............................................................................. 70

Appendix B-4. Americium-241 footnotes and references...................................................................................... 72

Appendix C-1. Radionuclide concentration summary of vegetation taken during the 1978 NMIRS

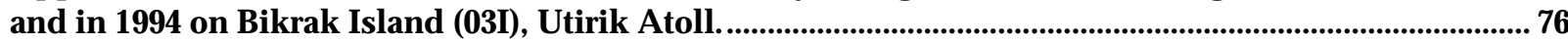

Appendix C-2. Radionuclide concentration summary for vegetation taken during the 1978 NMIRS

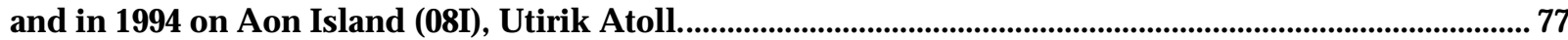

Appendix C-3. Radionuclide concentration summary for vegetation taken in 1994 on Elluk Island (02I), Utirik Atoll............................................................................................................................................................ 78

Appendix D-1. The daily intake in Bq d-1 decayed to 1998 from the diet models for IA and IUA........ 80 


\section{List of Figures}

Figure 1. Photo montage of Utirik Atoll.

4

Figure 2. Terrestrial exposure rate $\left(\mu \mathrm{R} \mathrm{h}^{-1}\right)$ contours for Utirik Island (I-6) and Bikrak Island (I-3)

Utirik Atoll. .5

Figure 3. Terrestrial exposure rate $\left(\mu \mathrm{R} \mathrm{h}^{-1}\right)$ contours for Aon Island (I-8), Utirik Atoll.............................. 6

Figure 4. Sampling grid for Utirik, Bikrak, and Aon Islands, Utirik Atoll. ................................................... 7

Figure 5. Vertical distribution of ${ }^{137} \mathrm{Cs}$ in soil-Utirik Island interior and village.....................................11

Figure 6. Vertical distribution of ${ }^{137} \mathrm{Cs}$ in soil for Aon and Bikrak Islands.................................................11

Figure 7. The total effective dose on Utirik Island compared with the background effective dose in the United States and Europe showing the various sub components making up the total doses..................27

Figure 8. The total integral $50 \mathrm{y}$ effective dose at Utirik Island compared with the effective $50 \mathrm{y}$ integral background dose in the United States and Europe 



\section{Utirik Atoll Dose Assessment}

Abstract-On March 1, 1954, radioactive fallout from the nuclear test at Bikini Atoll code-named BRAVO was deposited on Utirik Atoll which lies about $187 \mathrm{~km}$ (300 miles) east of Bikini Atoll. The residents of Utirik were evacuated three days after the fallout started and returned to their atoll in May 1954.

In this report we provide a final dose assessment for current conditions at the atoll based on extensive data generated from samples collected in 1993 and 1994. The estimated population average maximum annual effective dose using a diet including imported foods is $0.037 \mathrm{mSv} \mathrm{y}^{-1}\left(3.7 \mathrm{mrem}^{-1}\right)$. The $95 \%$ confidence limits are within a factor of three of their population average value. The population average integrated effective dose over 30-, 50-, and $70-y$ is $0.84 \mathrm{mSv}$ (84, mrem), $1.2 \mathrm{mSv}$ (120 mrem), and $1.4 \mathrm{mSv}$ (140 mrem), respectively. The 95\% confidence limits on the population-average value post 1998, i.e., the 30-, 50-, and 70-y integral doses, are within a factor of two of the mean value and are independent of time, $t$, for $t>5 \mathrm{y}$. Cesium-137 $\left({ }^{137} \mathrm{Cs}\right)$ is the radionuclide that contributes most of this dose, mostly through the terrestrial food chain and secondarily from external gamma exposure.

The dose from weapons-related radionuclides is very low and of no consequence to the health of the population. The annual background doses in the U. S. and Europe are $3.0 \mathrm{mSv}(300 \mathrm{mrem})$, and $2.4 \mathrm{mSv}$

(240 mrem), respectively. The annual background dose in the Marshall Islands is estimated to be $1.4 \mathrm{mSv}$ (140 mrem). The total estimated combined Marshall Islands background dose plus the weapons-related dose is about $1.5 \mathrm{mSv}^{-1}$ (150 mrem $\left.\mathrm{y}^{-1}\right)$ which can be directly compared to the annual background effective dose of $3.0 \mathrm{mSv}^{-1}$ (300 mrem $\left.\mathrm{y}^{-1}\right)$ for the U. S. and $2.4 \mathrm{mSv}^{-1}\left(240 \mathrm{mrem}^{-1}\right)$ for Europe.

Moreover, the doses listed in this report are based only on the radiological decay of ${ }^{137} \mathrm{Cs}$ (30.1 y half-life) and other radionuclides. However, we continually see ${ }^{137} \mathrm{Cs}$ in the groundwater at all contaminated atolls; the turnover time of the groundwater is about $5 \mathrm{y}$. The ${ }^{137} \mathrm{Cs}$ can only get to the groundwater by leaching through the soil column when a portion of the soluble fraction of ${ }^{137}$ Cs inventory in the soil is transported to the groundwater when rainfall is heavy enough to cause recharge of the acquifer. This process is causing a loss of ${ }^{137} \mathrm{Cs}$ out of the root zone of the plants that provides an environmental loss constant $\left(\lambda_{\text {env }}\right)$ in addition to radiological decay $\lambda_{\text {rad }}$. Consequently, there is an effective rate of loss, $\lambda_{\text {eff }}=\lambda_{\text {rad }}+\lambda_{\text {env }}$ that is the sum of the radiological and environmental-loss decay constants. We have had, and continue to have, a vigorous program to determine the rate of the environmental loss process. What we do know at this time is that the loss of ${ }^{137} \mathrm{Cs}$ over time is greater than the estimate based on radiological decay only, and that the actual dose received by the Utirik people over 30-, 50-, or 70$y$ will be less than those presented in this report.

\section{Introduction}

On March 1, 1954 radioactive fallout from the nuclear test at Bikini Atoll code-named BRAVO was deposited on Utirik Atoll, which lies about $187 \mathrm{~km}$ (300 miles) east of Bikini Atoll. The residents of Utirik were evacuated 3 days after the fallout started and returned to their atoll in May 1954.

In 1978 a radiological survey was conducted at 11 atolls and 2 islands in the northern Marshall Islands (Robison et al., 1981a) of which Utirik was one. The survey was called the Northern Marshall Island Radiological Survey (NMIRS). The NMIRS was designed as a screening survey to obtain limited but adequate data to determine the scale of radiological contamination at the various atolls and at the islands within the atolls. It included external gamma measurements, and collection and analysis of limited numbers of vegetation, soil, marine, animal, and fowl samples.

Dose estimates were made for each of the atolls based on the data developed in the NMIRS (Robison et al., 1982). More detailed and extensive sampling continued at Bikini, Enewetak, Rongelap, and Utirik Atolls over the next 21 years.

In this report we provide a final dose assessment for Utirik Atoll based on the extensive data generated from samples collected in 1993 and 1994. Details are provided for each of the exposure pathways, and the doses are calculated for residents living on Utirik in 1998 and projected to the year 2068. 


\section{Exposure Pathways}

The radiological dose to inhabitants at Utirik Atoll occurs from both external and internal exposure. Each of these two categories can be broken down further into the following exposure pathways:

(1) External Exposure

A. Background Radiation

B. Nuclear-Test-Related Radiation

(2) Internal Exposure

A. Background Radiation

B. Nuclear-Test-Related Radiation

1. Radionuclides in Terrestrial Foods

2. Radionuclides Inhaled

3. Radionuclides in Marine Foods

4. Radionuclides in Drinking Water

The above internal exposure pathways for nuclear-test-related radiation are listed in descending order of their contribution to the total estimated radiological dose at Utirik (and other atolls as well) (Robison et al., 1997). The terrestrial foods are of importance because of the uptake of ${ }^{137} \mathrm{Cs}$ by vegetation; $137 \mathrm{Cs}$ in these foods account for about $75 \%$ of the total estimated effective dose. The dose from the external gamma pathway is also due to ${ }^{137} \mathrm{Cs}$. Consequently, about $96 \%$ of the total estimated $50 \mathrm{y}$ integral effective dose at Utirik Island is due to ${ }^{137} \mathrm{Cs}$. The contribution of the Strontium$90\left({ }^{90} \mathrm{Sr}\right)$, Plutonium-239+240 $\left({ }^{239+240} \mathrm{Pu}\right)$, and Americium-241 $\left({ }^{241} \mathrm{Am}\right)$ is about $4 \%$ of the total estimated effective dose.

The external background radiation exposure in the northern Marshall Island Atolls including Utirik Atoll, is $3.3 \mu \mathrm{R} \mathrm{h}^{-1}$ or $0.22 \mathrm{mSv} \mathrm{y}^{-1}$ $\left(22 \mathrm{mrem} \mathrm{y}^{-1}\right)$ due to cosmic radiation (Gudiksen et al., 1976; Tipton and Meibaum, 1981). The external background dose due to terrestrial radiation is very low in the Marshall Islands. The internal effective dose is about 1.2 $\mathrm{mSv} \mathrm{y}^{-1}\left(122 \mathrm{mrem} \mathrm{y}^{-1}\right)$ for naturally occurring radionuclides such as 40 -Potassium $\left({ }^{40} \mathrm{~K}\right), 210$ Polonium $\left({ }^{210} \mathrm{Po}\right)$, and 210 -Lead $\left({ }^{210} \mathrm{~Pb}\right)$, that result from consumption of local and imported foods. The background dose in the Marshall Islands is summarized in Table 1. The background dose is not included in the doses presented in this paper unless specifically stated.

Table 1. Marshall Islands background dose.

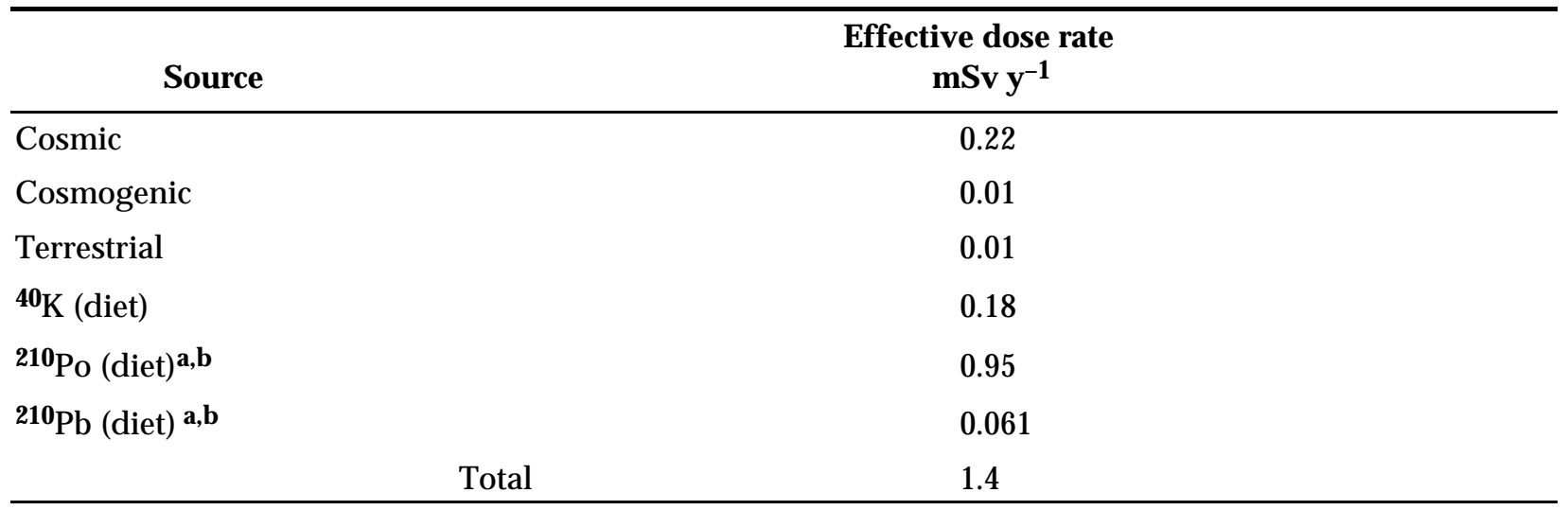

a Main source is fresh fish in the local diet (Noshkin et al., 1994).

b Doses are changed from previous reports (Noshkin et al., 1994; Robison et al., 1994) because these doses reflect the latest ICRP gut-transfer and dose-conversion factors for ${ }^{210} \mathrm{Po}$ and ${ }^{210} \mathrm{~Pb}$. 


\section{Databases}

\section{External Gamma Exposure Measurements}

The islands of Utirik Atoll are shown in the photomontage generated from Edgerton, Germeshausen, and Grier's (EG\&G) aerial photos taken in 1978 (Figure 1). The external exposure rates at Utirik Atoll were measured by EG\&G as part of the aerial survey conducted in the 1978 NMIRS (Tipton and Miebaum, 1981). Most of the external exposure in 1978 resulted from ${ }^{137} \mathrm{Cs}$; Cobalt- $60\left({ }^{60} \mathrm{Co}\right)$ with a 5.7 year half life contributed in a very minor way. There is essentially no ${ }^{60} \mathrm{Co}$ left on Utirik, Aon, or Bigrak Islands in 1998, so the external exposure is all due to ${ }^{137}$ Cs. Two major exposure contours of about equal area accounted for most of the island area for both Utirik and Aon Islands (Figures 2 and 3). The range of the contours was 0.30 to $0.65 \mu \mathrm{R} \mathrm{h}^{-1}$ and 0.65 to $1.4 \mu \mathrm{R} \mathrm{h} \mathrm{h}^{-1}$ above background. An island average number would be about $0.75 \mu \mathrm{R} \mathrm{h}{ }^{-1}$. A similar number is applicable to Bikrak Island. As a result of the radioactive decay of ${ }^{137} \mathrm{Cs}$, this would translate to an average exposure rate in 1998 of $0.47 \mu \mathrm{Rh}^{-1}$.

There were only a limited number of sampling sites on Utirik, Aon, and Bigrak Islands in the 1978 NMIRS. These sites were selected at random across the islands. In 1993 and 1994 LLNL conducted more detailed work on each of the islands at Utirik Atoll. Extensive sampling grids were established for Utirik, Aon, and Bikrak Islands in 1993/94 (Figure 4). Each sampling/measurement site is represented by a yellow dot.

External gamma exposure measurements were made in 1993/94 using in-situ gamma spectrometers at 42 of the sites on Aon Island, 20 of the sites on Bikrak Island, and 7 sites in the interior and 4 sites behind the houses in the village area on Utirik Island. The gamma detector height was 1 meter for all measurements. The results, decay corrected to 1998, are $0.47 \mu R \mathrm{~h}^{-1}$ for Aon and Utirik interior, and $0.51 \mu \mathrm{R} \mathrm{h}^{-1}$ for Bikrak (Table 2). The external exposure in the interior of all the islands is essentially the same at about $0.47 \mu R h^{-1}$. These results compare very well with the EG\&G measurements made in 1978 when the EG\&G data are decay corrected to 1998 . This is indicative of the relative uniform deposition at the atoll, as it is about $187 \mathrm{~km}$ downwind of the BRAVO test site.

The exposure rate from ${ }^{137} \mathrm{Cs}$ in the village area behind the houses on Utirik Island is about $0.15 \mu \mathrm{R} \mathrm{h}^{-1}$. This lower exposure in the village area relative to the interior area is consistent with our observations at Rongelap and Bikini Atolls. The ${ }^{137} \mathrm{Cs}$ external gamma exposure rates are lower in the housing and village areas, probably because they are located near the periphery of the island where the organic content of the soil is less both in amount and depth than the island interior, and leaching losses of ${ }^{137} \mathrm{Cs}$ are potentially greater. Moreover, the people tend to put crushed coral around their houses to reduce dust, and this results in the absorption and attenuation of the ${ }^{137} \mathrm{Cs}$ gamma rays. Based on measurements at Bikini and Rongelap, the exposure rate from ${ }^{137} \mathrm{Cs}$ inside the houses can be expected to be about half of that outside of the houses (Robison et al. 1994, 1997; McGraw and Lynch 1973) or about $0.08 \mu \mathrm{R} \mathrm{h}^{-1}$.

Fewer external exposure measurements were made in the interior of Utirik Island than on Aon and Bikrak because of the uniform distribution of radionuclides at the atoll, and the very intensive soil sampling conducted on Utirik Island (see next section of this report). 
Table 2. External gamma exposure at Utirik Atoll. ${ }^{\mathrm{a}}$

\begin{tabular}{lcc}
\hline \multicolumn{1}{c}{ Island } & No. of sites & $\begin{array}{c}\text { Median } \\
\text { exposure } \boldsymbol{\mu} \mathbf{R} \mathbf{~ h}^{\mathbf{- 1}}\end{array}$ \\
\hline Utirik & 7 & 0.47 \\
$\quad$ Interior & 4 & 0.15 \\
$\quad$ Behind houses & 42 & 0.47 \\
Aon & 20 & 0.51 \\
Bikrak & & \\
\hline
\end{tabular}

a Decay corrected to 1998.

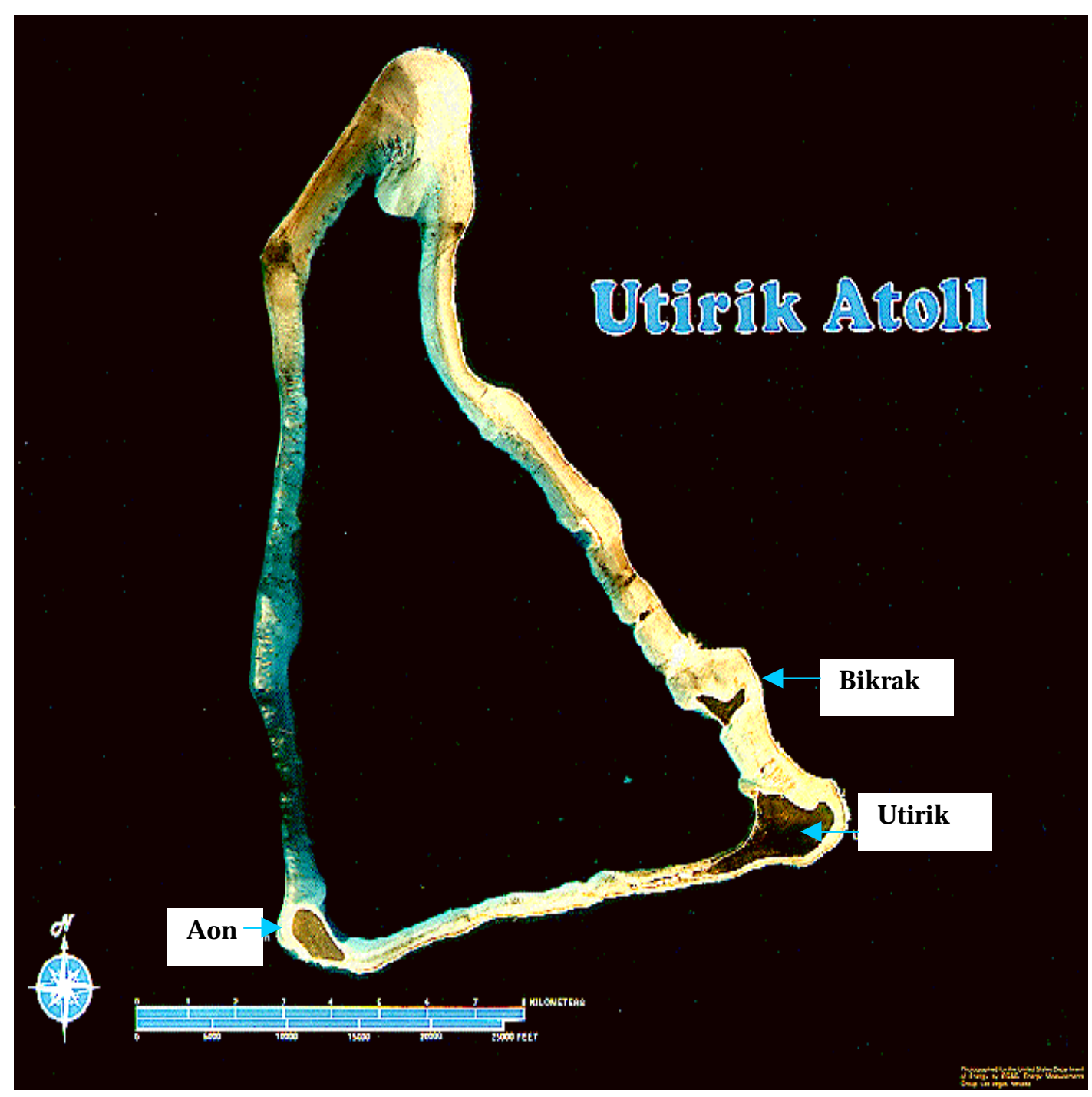

Figure 1. Photo montage of Utirik Atoll. 


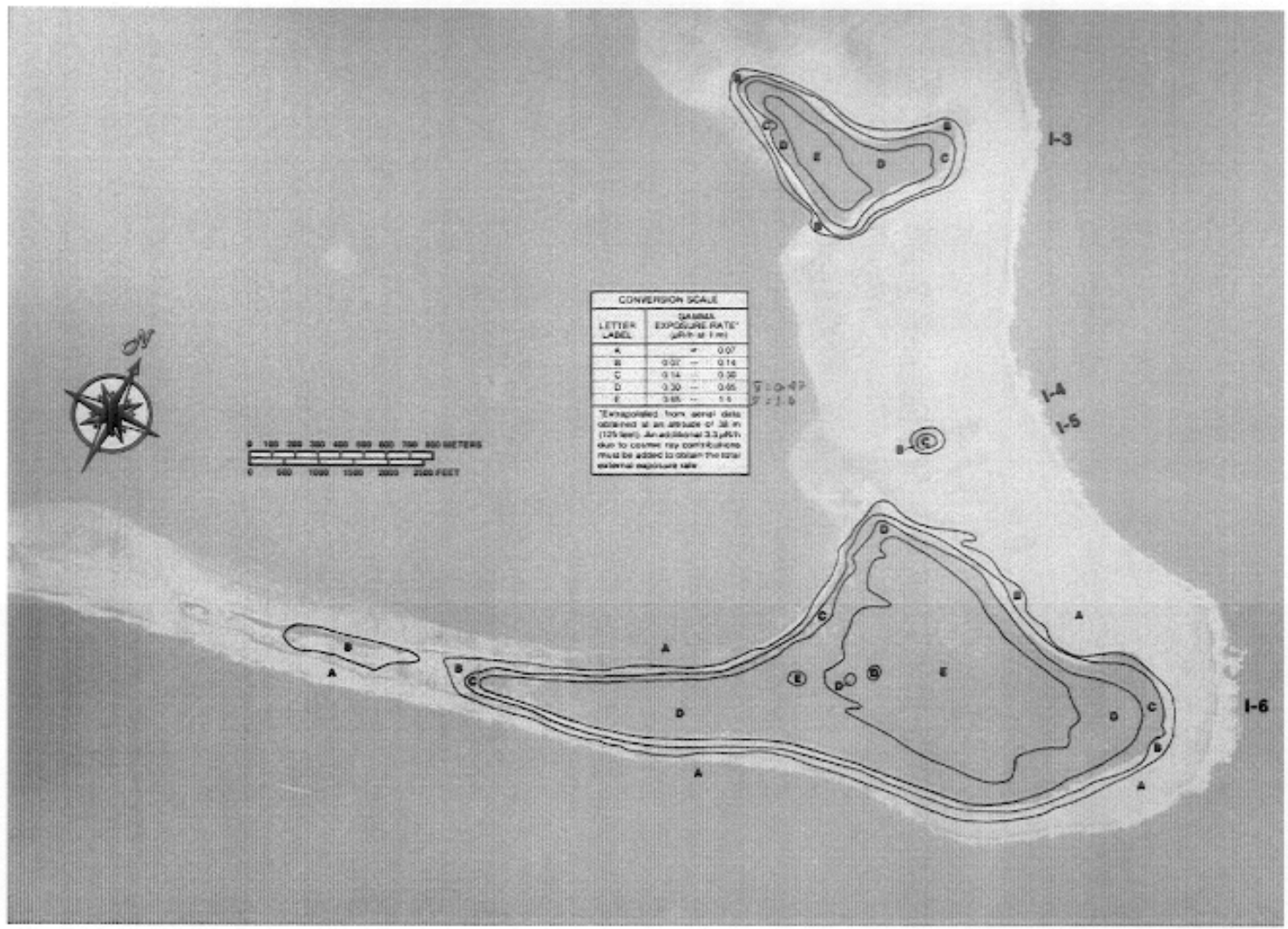

Figure 2. Terrestrial exposure rate $\left(\mu \mathrm{R} \mathrm{h}^{-1}\right)$ contours for Utirik Island (I-6) and Bikrak Island (I-3), Utirik Atoll. 


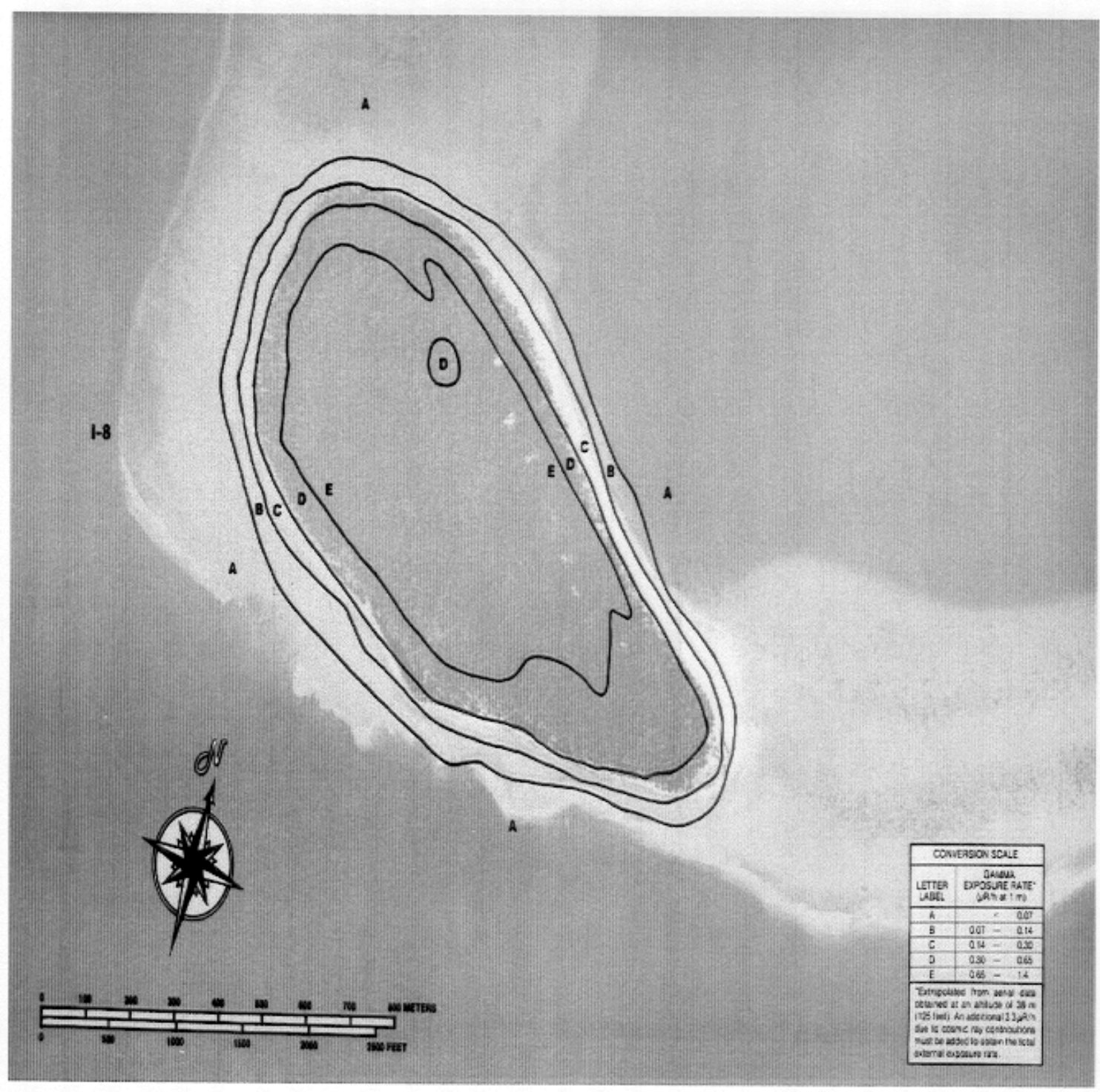

Figure 3. Terrestrial exposure rate $\left(\mu \mathrm{R} \mathrm{h}^{-1}\right)$ contours for Aon Island (I-8), Utirik Atoll. 

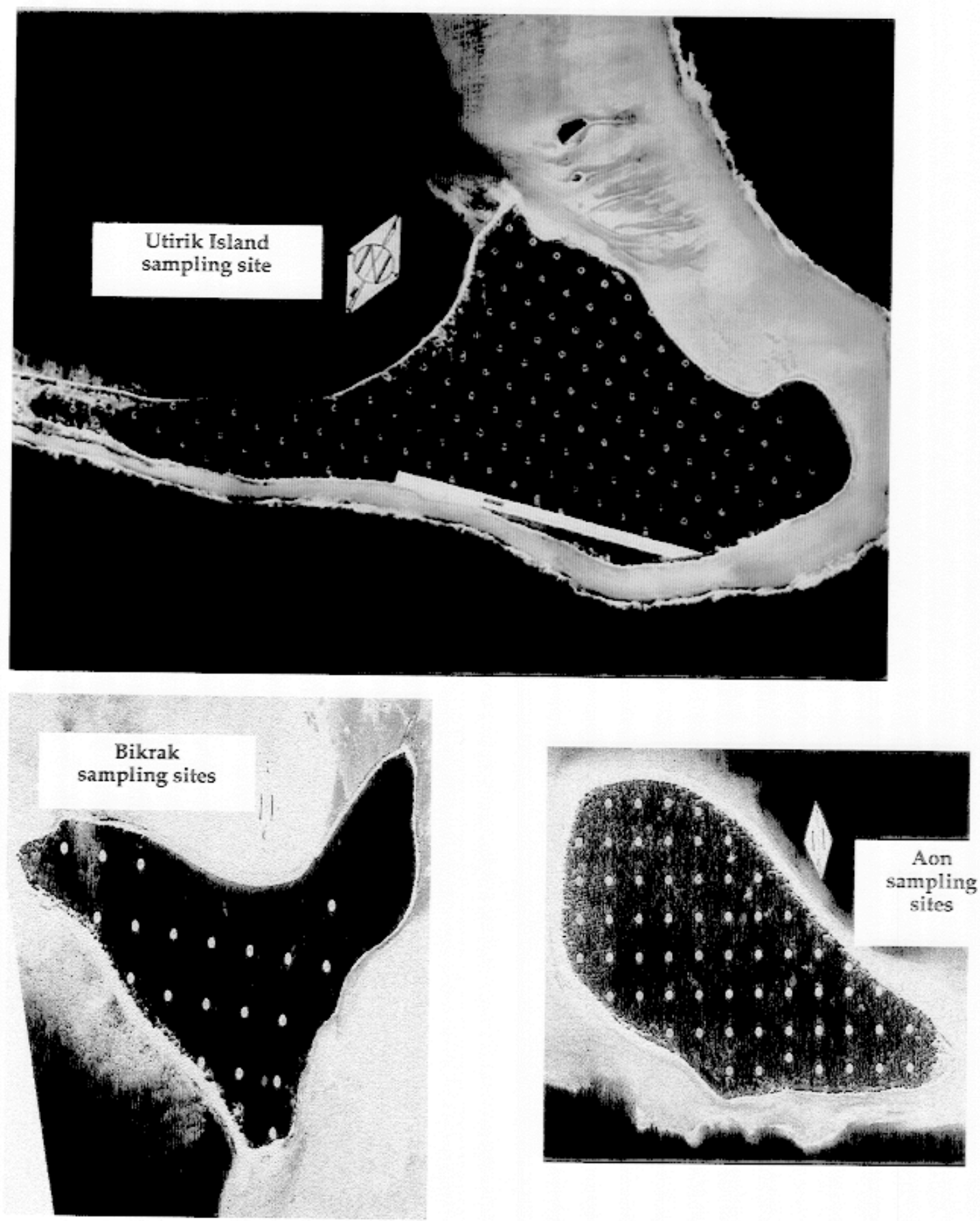

Figure 4. Sampling grid for Utirik, Bikrak, and Aon Islands, Utirik Atoll. The soil profiles were taken in the root of the coconut trees sampled (yellow dots in the photos) and near breadfruit and Pandanus trees wherever they were located, some of which were at the grid sampling sites. 


\section{External Beta-Particle Exposure}

The unshielded beta contribution to the external dose was estimated for Enjebi Island at Enewetak Atoll in 1980 (Crase et al., 1982). The average beta dose at 1-m height over open ground was $29 \%$ of the external gamma dose. The beta dose is delivered, for the most part, to the first centimeter of tissue, the so-called "shallow dose" and, therefore, should not be added to the external gamma dose in estimating the whole-body dose. Later studies at Bikini Atoll using new, thinner thermoluminescent dosimeters (TLDs) indicate that the dose over open ground at $1-\mathrm{cm}$ height is about three times that at 1-m height (Shingleton et al., 1987). Thus, the unshielded beta dose at 1-cm on Utirik Island could be equal to, or slightly greater than, the external gamma dose. For some portion of one day, people do sit or lie on the ground where the $1-\mathrm{cm}$ exposure may be relevant. However, for a significant part of the day, the eyes, upper body, and gonads are at $0.8 \mathrm{~m}$ or more in height above the ground surface.

Moreover, it is important to realize that the beta dose to skin, for a number of reasons, will be significantly less than that determined from the unshielded TLDs placed over open ground. The walls and floors of the houses and the crushed coral customarily placed around houses and the village area absorb most of the beta radiation. Because people spend a significant amount of their time in these areas, their exposure to beta particles is greatly reduced. In addition, any clothing, shoes, zories, Pandanus mats, or other coverings also greatly reduce exposure to beta radiation.

\section{Radionuclides in Soil Samples}

Soil profiles were collected as part of the NMIRS in 1978 but in limited numbers at the islands of Utirik, Aon, and Bikrak. A much greater number of soil profiles was collected in the 1993-94 surveys. The profile depth increments were: $0-5 \mathrm{~cm}, 5-10 \mathrm{~cm}, 10-15 \mathrm{~cm}$, $15-25 \mathrm{~cm}, 25-40 \mathrm{~cm}$, and in most cases, 40-60 cm. In the 1993-94 surveys, the soil profiles were taken in the root zone of the coconut trees we sampled (yellow dots in Figure 4), and near breadfruit and Pandanus trees wherever they were located, some of which were at the grid sampling sites.

\section{Utirik Island}

An intensive soil-sampling program was conducted on the main resident island of Utirik in 1993. Soil profiles were collected at 145 sites, which includes each of the vegetation collection sites shown in Figure 4, and other locations where breadfruit, Pandanus and other food crops were collected.

The soil samples collected on Utirik Island and analyzed at LLNL provide an assessment of the median concentrations of ${ }^{137} \mathrm{Cs}$ and ${ }^{241} \mathrm{Am}$ on the island both aerially and with depth (Table 3). The data from analysis of the soil samples can be used to compare with the radionuclide concentration data in the coconuts, breadfruit, Pandanus, etc., to determine the relative radionuclide concentration in plants and soil. The ${ }^{137} \mathrm{Cs}$ concentration data for soil also can be used to calculate the external gamma exposure rate verify the direct exposure measurements as well.

The median concentration of ${ }^{137} \mathrm{Cs}$ in the surface soil is about a factor of three lower in the housing and village area than in the island interior (Table 3). The ${ }^{241} \mathrm{Am}$ concentration in the interior is about twice that in the housing and village area. However, the ${ }^{241} \mathrm{Am}$ concentration is so low in the village area that the measurements are at the detection limit. Consequently, the ${ }^{241} \mathrm{Am}$ data are not as precise as the ${ }^{137} \mathrm{Cs}$ data. A general pattern of ${ }^{137} \mathrm{Cs}$, ${ }^{239+240} \mathrm{Pu}$, and ${ }^{241} \mathrm{Am}$ concentrations being about a factor of 2 to 4 lower in the village area has been observed at Bikini and Rongelap Atolls. This difference is included in calculations of resuspension and soil-ingestion doses. The ${ }^{241}$ Am concentrations are so low that below the surface $0-5 \mathrm{~cm}$ of the soil column the data are all detection limits, which is reflected in the almost constant concentration from 5 to $60 \mathrm{~cm}$. Consequently, the actual concentration is less than the values given in Table 3. Even the surface $0-5 \mathrm{~cm}$ data include some detection limit values.

\section{Aon, Bikrak, and Elluk Islands}

Fewer soil profiles were taken at Aon, Bikrak, and Elluk as shown in Table 4. The number of profiles taken on Aon and Bikrak was adequate to determine the distribution of the ${ }^{137}$ Cs with depth. This information, along with the extensive gamma exposure measurements 
Table 3. Cesium-137 and ${ }^{241} \mathrm{Am}$ concentration ${ }^{\mathbf{a}}$ in soil in the interior and village area of Utirik Island.

\begin{tabular}{|c|c|c|c|c|c|c|}
\hline \multirow[b]{3}{*}{$\begin{array}{l}\text { Soil depth } \\
\text { cm }\end{array}$} & \multicolumn{6}{|c|}{ Median concentration, $\mathrm{Bq} \mathrm{g}^{-1}$ dry wt. } \\
\hline & \multicolumn{3}{|c|}{ Island interior } & \multicolumn{3}{|c|}{ Village area } \\
\hline & $\begin{array}{c}\text { No. of } \\
\text { profiles }\end{array}$ & ${ }^{137} \mathrm{Cs}$ & ${ }^{241} \mathrm{Am}^{\mathrm{b}}$ & $\begin{array}{c}\text { No. of } \\
\text { profiles }\end{array}$ & ${ }^{137} \mathrm{Cs}$ & ${ }^{241} \mathrm{Am}^{\mathrm{b}}$ \\
\hline $0-5$ & 130 & 0.059 & 0.013 & 17 & 0.022 & $<0.0062$ \\
\hline $5-10$ & 127 & 0.019 & $<0.0057$ & 16 & 0.017 & $<0.0070$ \\
\hline $10-15$ & 129 & 0.0087 & $<0.0042$ & 16 & 0.0084 & $<0.0065$ \\
\hline $15-25$ & 127 & 0.0048 & $<0.0038$ & 17 & 0.0037 & $<0.0050$ \\
\hline $25-40$ & 126 & 0.0015 & $<0.0042$ & 16 & 0.0017 & $<0.0053$ \\
\hline $40-60$ & 123 & 0.00084 & $<0.0039$ & 15 & 0.0011 & $<0.0036$ \\
\hline
\end{tabular}

a Minimum detectable activities (MDA's) are included as data points where the analysis was below our detection limit (see Appendix A for details). 1978 data are not included. All data decay corrected to 1998.

$\mathrm{b}$ Detection limit numbers. The real is somewhere between zero and the listed number.

Table 4. The median ${ }^{137} \mathrm{Cs}$ concentration ${ }^{\mathrm{a}}$ with depth in the soil column at four islands of Utirik Atoll.

\begin{tabular}{|c|c|c|c|c|c|c|c|c|}
\hline \multirow[b]{3}{*}{$\begin{array}{l}\text { Soil } \\
\text { Depth } \\
\text { cm }\end{array}$} & \multicolumn{8}{|c|}{ Median ${ }^{137} \mathrm{Cs}$ concentration, $\mathrm{Bq}^{-1}$ dry wt. } \\
\hline & \multicolumn{2}{|c|}{ Utirik interior ${ }^{b}$} & \multicolumn{2}{|c|}{ Aonc ${ }^{c}$} & \multicolumn{2}{|c|}{ Bikrak $^{c}$} & \multicolumn{2}{|c|}{ Elluk $^{b}$} \\
\hline & $\begin{array}{c}\text { No. } \\
\text { of } \\
\text { profiles }\end{array}$ & ${ }^{137} \mathrm{Cs}$ & $\begin{array}{c}\text { No. } \\
\text { of } \\
\text { profiles }\end{array}$ & ${ }^{137} \mathrm{Cs}$ & $\begin{array}{c}\text { No. } \\
\text { of } \\
\text { profiles }\end{array}$ & ${ }^{137} \mathrm{Cs}$ & $\begin{array}{c}\text { No. } \\
\text { of } \\
\text { profiles }\end{array}$ & ${ }^{137} \mathrm{Cs}$ \\
\hline $0-5$ & 130 & 0.059 & 44 & 0.053 & 27 & 0.069 & 2 & 0.16 \\
\hline $5-10$ & 127 & 0.019 & 44 & 0.019 & 27 & 0.034 & 2 & 0.081 \\
\hline $10-15$ & 129 & 0.0087 & 44 & 0.011 & 27 & 0.018 & 2 & 0.032 \\
\hline $15-25$ & 127 & 0.0048 & 44 & 0.0050 & 27 & 0.0051 & 2 & 0.0046 \\
\hline $25-40$ & 126 & 0.0015 & 43 & 0.0020 & 27 & 0.0010 & 2 & 0.0005 \\
\hline $40-60$ & 123 & 0.00084 & 35 & 0.00073 & 27 & 0.00082 & & \\
\hline
\end{tabular}

a Minimum detectable activities (MDA's) are included as data points where the analysis was below our detection limit. All data decay corrected to 1998.

b Specific activity is based on determinations from samples taken in 1993/94.

c Specific activity is based on determinations from samples taken during the 1978 NMIRS and in 1994. 
made on both Aon and Bikrak, provide the basis to determine the concentration of ${ }^{137} \mathrm{Cs}$ in the soil at all of the sites where gamma exposure measurements were made. The summary results of the analysis of the soil samples on the three islands are shown in Table 4 along with those from the Utirik Island interior region. More detailed results are given in Appendix A for ${ }^{137} \mathrm{Cs}$ and include data for Utirik for ${ }^{90} \mathrm{Sr}$, ${ }^{239+240} \mathrm{Pu}$, and ${ }^{241} \mathrm{Am}$ and for Aon and Bikrak Islands, ${ }^{241} \mathrm{Am}$. One important feature is the somewhat similar concentration of ${ }^{137} \mathrm{Cs}$ at all depths for Utirik, Aon, and Bikrak where the data are all real numbers (i.e., no less than values) and where we have adequate profiles for comparison. With only two profiles from Elluk, it is difficult to say anything definitive, but the exponential decrease is very similar to the other islands. The profiles from all of the islands were taken, for the most part, in undisturbed areas of the islands. This reflects the uniform deposition pattern over the atoll on March 1, 1954 and the similar transport of ${ }^{137} \mathrm{Cs}$ down the soil column since that time.

\section{Utirik, Aon, and Bikrak Islands}

The difference in the distribution of ${ }^{137} \mathrm{Cs}$ with depth in the soil in the interior and village areas of Utirik Island is shown in Figure 5. The reciprocal of the slope of the line, which is the depth at which the ${ }^{137}$ Cs activity drops to $37 \%$ of its surface value, is a measure of the difference in the distribution with depth. This value, called the "relaxation depth," is about $8.7 \mathrm{~cm}$ for the interior of the island and about $11 \mathrm{~cm}$ for the village area. Thus, a slightly different conversion factor is required to convert the village-area external gamma count rate to the concentration of ${ }^{137} \mathrm{Cs}$ in the soil column.

The distribution of median ${ }^{137} \mathrm{Cs}$ concentrations with depth for Aon and Bikrak Islands is given in Figure 6. The relaxation depth for Aon is about $9.5 \mathrm{~cm}$ and for Bikrak about 7 $\mathrm{cm}$. The mean value for the relaxation depth for the undisturbed areas (Aon Island, Bikrak Island, and the interior of Utirik Island) is 8.4 $\mathrm{cm}$, with the range of $7 \mathrm{~cm}$ to $9.5 \mathrm{~cm}$. The relaxation depth for the interior of Utirik Island and that of Aon Island are within the statistical uncertainty of the measurement. (Even with Bikrak included, the relaxation depth is very similar for all islands.) The relaxation depth of $11 \mathrm{~cm}$ for the village area of Utirik Island is distinctly different from the relaxation length observed in the interior of all the islands.

\section{Airborne Radionuclide Concentrations}

Airborne concentrations of ${ }^{239+240} \mathrm{Pu}$ and ${ }^{241} \mathrm{Am}$ are estimated from data developed in resuspension experiments conducted at Enewetak Atoll, Enjebi Island in February 1977, and Runit Island in May 1995, at Bikini Atoll in May 1978, and at Rongelap Island in May 1992 and 1996. We briefly describe the resuspension methodology here; more detail can be found in Shinn et al. (1997), and Robison et al. (1997). The dose from ${ }^{137} \mathrm{Cs}$ and ${ }^{90} \mathrm{Sr}$ are orders of magnitude lower than that from ${ }^{239+240} \mathrm{Pu}$ and ${ }^{241} \mathrm{Am}$ and, consequently, are not listed.

Concentrations of ${ }^{239+240} \mathrm{Pu}$ in collected aerosols were determined in areas (1) with normal ground cover and conditions in coconut groves, (2) with high-activity conditions, i.e., areas being cleared by bulldozers and being tilled, and (3) with stabilized bare soil, i.e., cleared areas after a few days of weathering. The plutonium concentration in the collected aerosols is different from the plutonium concentration in surface soil for each of these situations. We have defined an enhancement factor (EF) as the ${ }^{239+240} \mathrm{Pu}$ concentration in the collected soil aerosol mass (corrected for sea-salt mass) divided by the ${ }^{239+240} \mathrm{Pu}$ concentration in surface-soil (0- to 5-cm).

The EF obtained for normal conditions (using standard, high-volume air samplers) is less than 1; the EF for the worst-case, high resuspension conditions is 3. The observed EF's at Bikini and Enewetak Atolls are summarized in Table 5. The EF of less than $1(\mathrm{EF}<1)$ for the normal, open-air conditions is apparently the result of selective particle resuspension in which the resuspended particles have a different plutonium concentration than is observed in the total 0- to 5-cm soil sample. In other words, the particle size and density, and the corresponding radionuclide concentration of normally resuspended material, is different from that of a representative 0 - to 5 - $\mathrm{cm}$ soil sample. In addition, approximately $10 \%$ of the mass observed on the filter is organic matter, which has a much lower $\mathrm{Pu}$ concentration than the soil. Similarly, the enhancement factor of 3 for highresuspension conditions results from the increased resuspension of particle sizes with a 


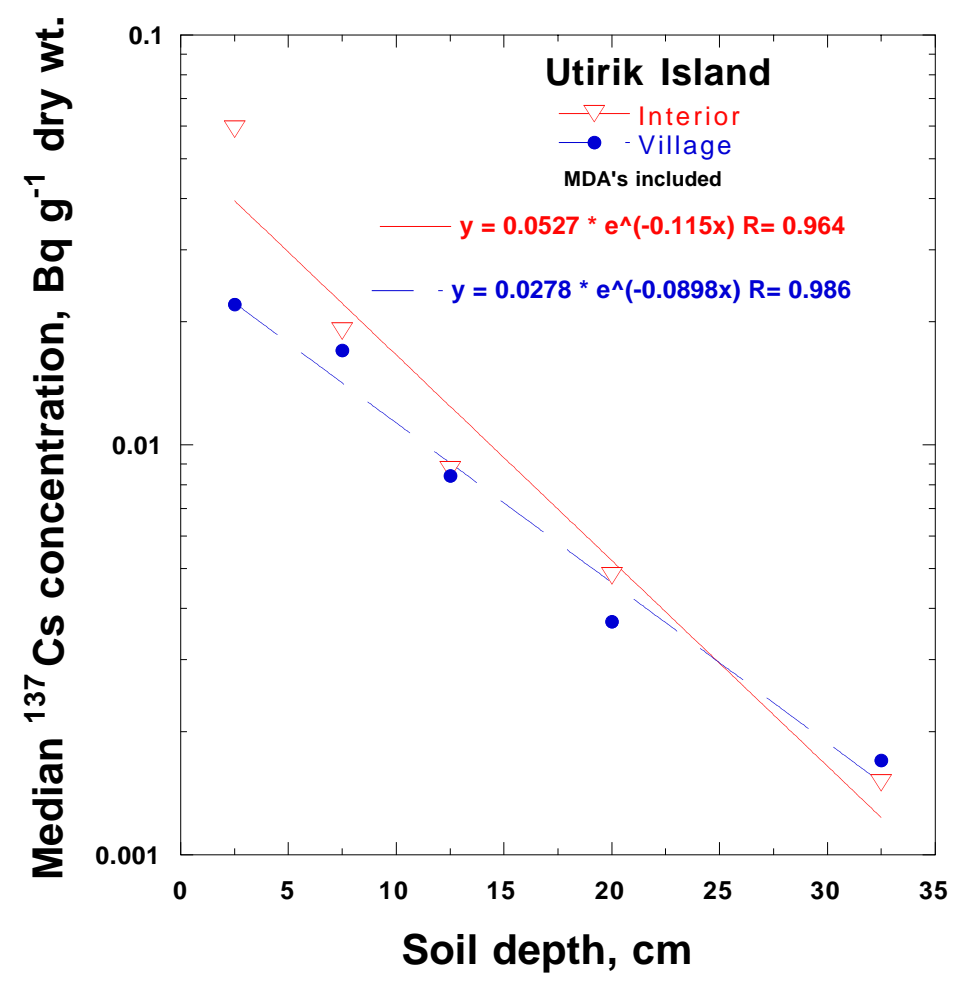

Figure 5. Vertical distribution of ${ }^{137} \mathrm{Cs}$ in soil-Utirik Island interior and village.

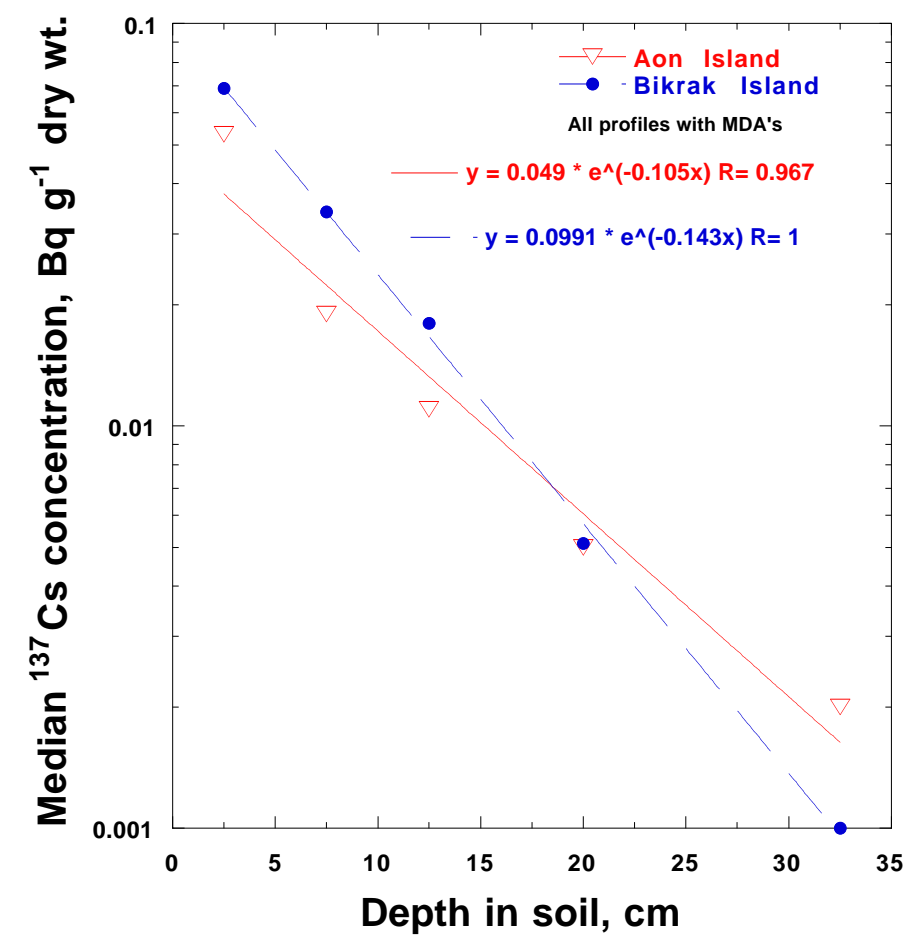

Figure 6. Vertical distribution of ${ }^{137} \mathrm{Cs}$ in soil for Aon and Bikrak Islands. 
Table 5. Resuspension data for high and low resuspension conditions on Bikini and Enewetak Atolls (239+240Pu).

\begin{tabular}{|c|c|c|c|c|c|c|c|c|c|c|c|c|}
\hline Location & $\begin{array}{c}\text { Surface } \\
\text { description }\end{array}$ & $\begin{array}{l}\text { Dust } \\
\text { aerosol } \\
\left.\mu \mathrm{g} \mathrm{m}^{-3}\right)\end{array}$ & $\begin{array}{c}\begin{array}{c}\text { Plutonium } \\
\text { aerosol }\end{array} \\
\text { concentration } \\
\left(\mu \mathrm{Bq} \mathrm{m}^{-3}\right)\end{array}$ & $\begin{array}{l}\text { Suspended } \\
\text { soil } \\
\text { activity } \\
\left(\mathrm{Bq} \mathrm{g}^{-1}\right) \\
\end{array}$ & & $\begin{array}{l}\text { Surfac } \\
\text { plutor } \\
\text { activ } \\
\text { (Bqg }\end{array}$ & & $\begin{array}{l}\text { Enhancement } \\
\text { factor }(E F)^{a}\end{array}$ & & $\begin{array}{c}\text { Personal } \\
\text { enhancement } \\
\text { factor (PEF) }\end{array}$ & & $\begin{array}{c}\text { Total } \\
\text { enhancement } \\
\text { factor (TEF) }\end{array}$ \\
\hline \multicolumn{13}{|c|}{ Normal "background" } \\
\hline Bikini & Coconut grove & 18 & 2.2 & 0.12 & $\div$ & 0.30 & $=$ & 0.40 & $x$ & 1.1 & $=$ & 0.44 \\
\hline Bikini & Stabilized bare soil & 21 & 9.8 & 0.47 & $\div$ & 0.57 & $=$ & 0.82 & $x$ & 2.6 & $=$ & 2.2 \\
\hline Enjebi $^{b}$ & Vegetated field & 22 & 8.9 & 0.40 & $\div$ & 0.90 & $=$ & 0.44 & & & & \\
\hline Bikini & $\begin{array}{l}\text { In and around house, } \\
\text { light work }\end{array}$ & 21 & 9.8 & 0.47 & $\div$ & 0.57 & $=$ & 0.82 & $x$ & 1.9 & $=$ & 1.5 \\
\hline \multicolumn{13}{|c|}{ Unusual conditions } \\
\hline Bikini & Field, freshly tilled & 136 & 239 & 1.8 & $\div$ & 0.57 & $=$ & 3.1 & $x$ & 0.92 & $=$ & 2.9 \\
\hline Enjebi ${ }^{b}$ & Garden, freshly tilled & & 275 & & & 0.90 & & 4.4 & & & & \\
\hline Enjebi ${ }^{b}$ & Garden, $1 \mathrm{wk}$. after tille & ed & 113 & & & 0.90 & & 2.6 & & & & \\
\hline Bikini & Road with traffic & 28 & 16 & 0.38 & $\div$ & 0.15 & $=$ & 2.5 & $x$ & 1.0 & $=$ & 2.5 \\
\hline Enjebi ${ }^{b}$ & Downwind of road & & 40 & & & 1.3 & & 0.56 & & & & \\
\hline
\end{tabular}

a Calculated by assuming $34 \mu \mathrm{g} \mathrm{m}^{-3}$ sea spray that has been verified by measurement on Bikini.

b Enjebi Island, Enewetak Atoll. 
higher plutonium concentration than that observed in the total 0 - to 5 -cm soil sample.

We have developed additional personal enhancement factors (PEF factors) from personal air sampler data. These data are normalized to the high-volume air sampler data for a particular condition and represent the enhancement that occurs around individuals due to their daily activities. These data are also summarized in Table 5. The total enhancement factor used to estimate the amount of suspended plutonium is the EF multiplied by the PEF. Consequently, the total enhancement factor (TEF) used for normal resuspension conditions is $1.5(0.82 \times 1.9)$ and for high resuspension conditions, $2.9(3.1 \times 0.92)$.

To calculate inhalation exposure, we assume that a person spends $1 \mathrm{~h} \mathrm{~d}^{-1}$ in high resuspension conditions (mass loading $=136 \mu \mathrm{g}$ $\mathrm{m}^{-3}$ ), $23 \mathrm{~h} \mathrm{~d}^{-1}$ under normal resuspension conditions (mass loading $=21 \mu \mathrm{g} \mathrm{m}^{-3}$ ), and has a breathing rate of $22.1 \mathrm{~m}^{3}$ per day $\left(1.2 \mathrm{~m}^{3}\right.$ under high resuspension conditions and $20.9 \mathrm{~m}^{3}$ under normal resuspension conditions). The average breathing rate of $22.1 \mathrm{~m}^{3} \mathrm{~d}^{-1}$ is based on the average value from ICRP for male and females. This value is considerably higher than those calculated by Layton (Layton, 1993) based on dietary intake and average daily energy expenditure.

The radionuclide concentrations in surface soil (0- to 5- $\mathrm{cm}$ ) for Utirik Island complete the information necessary for calculation of plutonium and americium intake through inhalation.

The median ${ }^{239+240} \mathrm{Pu}$ and ${ }^{241} \mathrm{Am}$ concentration in surface soil in the island interior region is higher than the ${ }^{239+240} \mathrm{Pu}$ and ${ }^{241} \mathrm{Am}$ concentration in surface soil in the village and housing area (Table 3 ). We assume for the 1 $\mathrm{h} \mathrm{d}^{-1}$ in high resuspension conditions, that the resuspended soil aerosol is based on the island interior value for $\mathrm{Pu}$ and $\mathrm{Am}$ concentration in surface soil and that a person breaths $1.2 \mathrm{~m}^{3}$ of air during that $1 \mathrm{~h}$ period. The $23 \mathrm{~h}$ spent in normal resuspension conditions is broken down as follows:

- $\quad 2 \mathrm{~h} \mathrm{~d}^{-1}$ in non-occupational activity conditions in the island interior (island interior median $\mathrm{Pu}$ and $\mathrm{Am}$ concentrations in soil) in which $2.4 \mathrm{~m} 3$ of air is breathed.
- $9 \mathrm{~h} \mathrm{~d}-1$ in non-occupational activity in the village area (village median $\mathrm{Pu}$ and $\mathrm{Am}$ concentration in soil) in which $10.8 \mathrm{~m} 3$ of air is breathed.

- $10 \mathrm{~h} \mathrm{~d}-1$ in resting conditions in the village area (village median $\mathrm{Pu}$ and $\mathrm{Am}$

concentrations in soil) in which $5.3 \mathrm{~m} 3$ of air is breathed.

- $2 \mathrm{~h} \mathrm{~d}-1$ on the beach or lagoon (essentially no exposure) at $2.4 \mathrm{~m} 3$ of air breathed.

The total daily intake of ${ }^{239+240} \mathrm{Pu}$ and ${ }^{241} \mathrm{Am}$ via inhalation based on all of the above data is $1.4 \times 10^{-5} \mathrm{~Bq} \mathrm{~d}^{-1}$ for ${ }^{239+240} \mathrm{Pu}$ and $1.2 \times$ $10^{-5} \mathrm{~Bq} \mathrm{~d}^{-1}$ for ${ }^{241} \mathrm{Am}$.

\section{Radionuclides in Drinking Water}

The radionuclides in drinking water contribute a small portion of the total estimated dose at Utirik Island. The major source of water used for cooking and drinking is rainwater that is collected from roofs of houses and other buildings, and stored in various containment vessels. The main source of radionuclides in the catchment water is vegetation that falls into containment vessels and resuspended dust washed off of roofs when it rains. If extreme drought conditions occur, then the freshest ground water available is used.

We collected ground water samples from four wells in 1993 and one cistern water sample during the NMIRS. The results are listed in Table 6 . The radionuclide concentrations in the ground water are always higher than the rainwater at all of the atolls.

For the dose estimates, we use an intake of 1 $\mathrm{L} \mathrm{d}^{-1}$ of drinking water. We assume for the dose assessment that cistern water is available for $60 \%$ of the year and that ground water is used for $40 \%$ of the year. The people are very fond of soda (colas, orange soda, root beer, and others) and fruit drinks. These drinks are frequently available and account for some of the daily fluid intake. The total daily drinking fluid intake from all these sources is between 2 and $2.5 \mathrm{~L} \mathrm{~d}^{-1}$. Water consumption from foods (soups, etc.) is not included.

\section{Radionuclides in Terrestrial Foods}

The mean concentrations of radionuclides in food crops grown on Utirik Island are listed in 
Table 6. The radionuclide concentrations in foods, water, and surface soil from Utirik Island and the diet model shown as the grams per day intake of each food item.

\begin{tabular}{|c|c|c|c|c|c|c|c|c|c|}
\hline \multirow[b]{2}{*}{ Local Food } & \multicolumn{2}{|c|}{$\begin{array}{c}\text { Imported foods } \\
\text { diet }\end{array}$} & \multicolumn{3}{|c|}{$\begin{array}{c}\text { Local foods only } \\
\text { diet }\end{array}$} & \multicolumn{4}{|c|}{ Specific Activity in $1998,\left(\mathrm{~Bq} \mathrm{~g}^{-1} \text { wet wt. }\right)^{\mathrm{c}}$} \\
\hline & Grams d $^{-1}$ & kcal d $^{-1}$ & Grams d $^{-1}$ & $1 \mathrm{kcal} \mathrm{d}^{-1}$ & $\mathbf{k c a l ~ g}^{-\mathbf{1}^{\mathrm{a}, \mathrm{l}}}$ & b ${ }^{137} \mathrm{Cs}$ & ${ }^{90} \mathrm{Sr}$ & ${ }^{239+240} \mathrm{Pu}$ & ${ }^{241} \mathrm{Am}$ \\
\hline Reef fish & 24.2 & 33.8 & 62.5 & 87.5 & 1.40 & $2.9 \times 10^{-4}$ & $1.5 \times 10^{-5}$ & $3.7 \times 10^{-6}$ & $3.7 \times 10^{-7}$ \\
\hline Tuna & 13.9 & 19.4 & 51.9 & 72.6 & 1.40 & $4.9 \times 10^{-4}$ & $9.4 \times 10^{-6}$ & $2.0 \times 10^{-7}$ & $7.4 \times 10^{-8}$ \\
\hline Mahi Mahi & 3.56 & 3.92 & 15.4 & 16.9 & 1.10 & $4.9 \times 10^{-4}$ & $9.4 \times 10^{-6}$ & $2.0 \times 10^{-7}$ & $7.4 \times 10^{-8}$ \\
\hline Marine crabs & 1.68 & 1.51 & 14.04 & 12.64 & 0.90 & $1.4 \times 10^{-4}$ & $3.0 \times 10^{-5}$ & $1.0 \times 10^{-5}$ & $1.5 \times 10^{-6}$ \\
\hline Lobster & 3.88 & 3.49 & 25.4 & 22.8 & 0.90 & $1.4 \times 10^{-4}$ & $3.0 \times 10^{-5}$ & $1.0 \times 10^{-5}$ & $1.5 \times 10^{-6}$ \\
\hline Clams & 4.56 & 3.65 & 41.8 & 33.5 & 0.80 & $1.8 \times 10^{-5}$ & $5.8 \times 10^{-5}$ & $1.6 \times 10^{-5}$ & $3.9 \times 10^{-6}$ \\
\hline Trochus & 0.10 & 0.08 & 0.17 & 0.14 & 0.80 & $1.8 \times 10^{-5}$ & $5.8 \times 10^{-5}$ & $1.6 \times 10^{-5}$ & $3.9 \times 10^{-6}$ \\
\hline Tridacna muscle & 1.67 & 2.14 & 8.24 & 10.54 & 1.28 & $1.8 \times 10^{-5}$ & $5.8 \times 10^{-5}$ & $1.6 \times 10^{-5}$ & $3.9 \times 10^{-6}$ \\
\hline Jedrul & 3.08 & 2.46 & 13.95 & 12.56 & 0.90 & $1.8 \times 10^{-5}$ & $5.8 \times 10^{-5}$ & $1.6 \times 10^{-5}$ & $3.9 \times 10^{-6}$ \\
\hline Coconut crabs & 3.13 & 2.19 & 18.0 & 12.57 & 0.70 & $4.3 \times 10^{-2}$ & $4.2 \times 10^{-3}$ & $5.9 \times 10^{-5}$ & $1.9 \times 10^{-5}$ \\
\hline Octopus & 4.51 & 4.51 & 35.3 & 35.3 & 1.00 & $1.8 \times 10^{-4}$ & $1.5 \times 10^{-5}$ & $3.7 \times 10^{-6}$ & $3.7 \times 10^{-7}$ \\
\hline Turtle & 4.34 & 3.86 & 12.79 & 11.38 & 0.89 & $2.8 \times 10^{-5}$ & $1.5 \times 10^{-5}$ & $3.7 \times 10^{-6}$ & $3.7 \times 10^{-7}$ \\
\hline Chicken muscle & 8.36 & 14.2 & 22.4 & 38.2 & 1.70 & $1.3 \times 10^{-2}$ & $1.8 \times 10^{-4}$ & $9.5 \times 10^{-7}$ & $1.9 \times 10^{-6}$ \\
\hline Chicken liver & 4.50 & 7.38 & 12.73 & 20.9 & 1.64 & $7.5 \times 10^{-3}$ & $3.5 \times 10^{-3}$ & $9.5 \times 10^{-7}$ & $1.1 \times 10^{-5}$ \\
\hline Chicken gizzard & 1.66 & 2.46 & 2.39 & 3.54 & 1.48 & $6.5 \times 10^{-3}$ & $4.9 \times 10^{-4}$ & $1.1 \times 10^{-5}$ & $9.8 \times 10^{-6}$ \\
\hline Pork muscle & 5.67 & 25.5 & 10.02 & 45.1 & 4.50 & $7.8 \times 10^{-2}$ & $1.6 \times 10^{-5}$ & $4.0 \times 10^{-7}$ & $6.2 \times 10^{-7}$ \\
\hline Pork liver & 2.60 & 6.27 & 4.82 & 11.63 & 2.41 & $4.1 \times 10^{-2}$ & $2.9 \times 10^{-5}$ & $5.6 \times 10^{-6}$ & $3.1 \times 10^{-6}$ \\
\hline Pork heart & 0.31 & 0.61 & 0.45 & 0.87 & 1.95 & $4.7 \times 10^{-2}$ & $1.6 \times 10^{-5}$ & $4.0 \times 10^{-7}$ & $6.2 \times 10^{-7}$ \\
\hline Bird muscle & 2.71 & 4.61 & 19.0 & 32.3 & 1.70 & $2.9 \times 10^{-4}$ & $1.5 \times 10^{-5}$ & $3.7 \times 10^{-6}$ & $3.7 \times 10^{-7}$ \\
\hline Bird eggs & 1.54 & 2.31 & 16.4 & 24.6 & 1.50 & $7.9 \times 10^{-5}$ & $2.4 \times 10^{-5}$ & $3.7 \times 10^{-6}$ & $3.7 \times 10^{-7}$ \\
\hline Chicken eggs & 7.25 & 11.8 & 29.7 & 48.4 & 1.63 & $1.3 \times 10^{-2}$ & $1.8 \times 10^{-4}$ & $9.5 \times 10^{-7}$ & $1.9 \times 10^{-6}$ \\
\hline Turtle eggs & 9.36 & 14.0 & 169 & 254 & 1.50 & $2.8 \times 10^{-5}$ & $1.5 \times 10^{-5}$ & $3.7 \times 10^{-6}$ & $3.7 \times 10^{-7}$ \\
\hline Pandanus fruit & 8.66 & 5.20 & 45.3 & 27.2 & 0.60 & $4.5 \times 10^{-2}$ & $2.2 \times 10^{-3}$ & $2.1 \times 10^{-6}$ & $3.2 \times 10^{-6}$ \\
\hline Pandanus nuts & 0.50 & 1.33 & 1.44 & 3.83 & 2.66 & $4.5 \times 10^{-2}$ & $2.2 \times 10^{-3}$ & $2.1 \times 10^{-6}$ & $3.2 \times 10^{-6}$ \\
\hline Breadfruit & 27.2 & 35.3 & 134.0 & 174 & 1.30 & $1.8 \times 10^{-2}$ & $4.2 \times 10^{-4}$ & $5.5 \times 10^{-7}$ & $7.3 \times 10^{-7}$ \\
\hline Coconut juice & 99.1 & 10.9 & 240 & 26.4 & 0.11 & $8.3 \times 10^{-3}$ & $5.6 \times 10^{-5}$ & $9.5 \times 10^{-7}$ & $2.3 \times 10^{-6}$ \\
\hline Coconut milk & 51.9 & 179 & 87.7 & 303 & 3.46 & $2.8 \times 10^{-2}$ & $6.9 \times 10^{-5}$ & $2.2 \times 10^{-6}$ & $3.4 \times 10^{-6}$ \\
\hline $\begin{array}{l}\text { Drinking coco } \\
\text { meat }\end{array}$ & 31.7 & 32.3 & 130.1 & 132.7 & 1.02 & $1.7 \times 10^{-2}$ & $6.9 \times 10^{-5}$ & $2.2 \times 10^{-6}$ & $3.4 \times 10^{-6}$ \\
\hline Copra meat & 12.2 & 50.3 & 51.3 & 213 & 4.14 & $2.8 \times 10^{-2}$ & $6.9 \times 10^{-5}$ & $2.2 \times 10^{-6}$ & $3.4 \times 10^{-6}$ \\
\hline Sprout. coco & 7.79 & 6.23 & 88.1 & 70.4 & 0.80 & $2.8 \times 10^{-2}$ & $6.9 \times 10^{-5}$ & $2.2 \times 10^{-6}$ & $3.4 \times 10^{-6}$ \\
\hline Marsh. cake & 11.7 & 39.2 & 0.00 & 0.00 & 0.76 & $2.8 \times 10^{-2}$ & $6.9 \times 10^{-5}$ & $2.2 \times 10^{-6}$ & $3.4 \times 10^{-6}$ \\
\hline Papaya & 6.59 & 2.6 & 19.4 & 7.57 & 0.39 & $5.4 \times 10^{-2}$ & $3.1 \times 10^{-4}$ & $2.3 \times 10^{-7}$ & $8.9 \times 10^{-7}$ \\
\hline Pumpkin & 1.24 & 0.37 & 3.92 & 1.18 & 0.30 & $1.0 \times 10^{-2}$ & $6.1 \times 10^{-4}$ & $1.8 \times 10^{-7}$ & $1.1 \times 10^{-7}$ \\
\hline Banana & 0.02 & 0.02 & 0.42 & 0.37 & 0.88 & $7.3 \times 10^{-3}$ & $1.8 \times 10^{-4}$ & $5.2 \times 10^{-7}$ & $8.9 \times 10^{-7}$ \\
\hline Arrowroot & 3.93 & 13.6 & 68.3 & 236 & 3.46 & $1.9 \times 10^{-3}$ & $3.1 \times 10^{-4}$ & $3.5 \times 10^{-6}$ & $7.9 \times 10^{-7}$ \\
\hline Citrus & 0.10 & 0.05 & 0.14 & 0.07 & 0.49 & $1.8 \times 10^{-2}$ & $4.2 \times 10^{-4}$ & $5.5 \times 10^{-7}$ & $7.3 \times 10^{-7}$ \\
\hline Rainwater & 313 & 0.0 & 453 & 0.00 & 0.00 & $3.3 \times 10^{-6}$ & $2.3 \times 10^{-6}$ & $1.9 \times 10^{-8}$ & $7.4 \times 10^{-9}$ \\
\hline Well water & 207 & 0.0 & 310 & 0.00 & 0.00 & $6.7 \times 10^{-5}$ & $1.9 \times 10^{-6}$ & $7.4 \times 10^{-9}$ & $3.7 \times 10^{-10}$ \\
\hline Malolo & 199 & 0.0 & 0.00 & 0.00 & 0.00 & $3.3 \times 10^{-6}$ & $2.3 \times 10^{-6}$ & $1.9 \times 10^{-8}$ & $7.4 \times 10^{-9}$ \\
\hline Coffee/tea & 228 & 0.0 & 0.00 & 0.00 & 0.00 & $3.3 \times 10^{-6}$ & $2.3 \times 10^{-6}$ & $1.9 \times 10^{-8}$ & $7.4 \times 10^{-9}$ \\
\hline Soil & 0.1 & 0.0 & 0.1 & 0.00 & 0.00 & $3.7 \times 10^{-2}$ & $1.9 \times 10^{-2}$ & $1.0 \times 10^{-2}$ & $9.2 \times 10^{-3}$ \\
\hline Total local & 1322 & 547 & 2219 & 2004 & & & & & \\
\hline Fluids & 1046 & 11 & 1002 & 26 & & & & & \\
\hline Solids & 276 & 536 & 1217 & 1978 & & & & & \\
\hline
\end{tabular}


Table 6. Continued.

\begin{tabular}{|c|c|c|c|}
\hline Imported food & Grams d $^{-1}$ & $\mathrm{kcal} \mathrm{d}^{-1}$ & $\mathrm{kcal} \mathrm{g}^{-1} \mathrm{a}, \mathrm{b}$ \\
\hline Baked bread & 30.3 & 83.3 & 2.75 \\
\hline Fried bread & 72.0 & 306 & 4.25 \\
\hline Pancakes & 59.5 & 130 & 2.18 \\
\hline Cake & 2.64 & 8.63 & 3.27 \\
\hline Rice & 234 & 257 & 1.10 \\
\hline $\begin{array}{l}\text { Instant mashed } \\
\text { potatoes }\end{array}$ & 127 & 114 & 0.90 \\
\hline Sugar & 65.2 & 251 & 3.85 \\
\hline Canned chicken & 13.0 & 25.7 & 1.98 \\
\hline Corned beef & 78.7 & 170 & 2.16 \\
\hline Spam & 55.0 & 125 & 2.28 \\
\hline Canned mackerel & 44.0 & 80.5 & 1.83 \\
\hline Canned sardines & 42.5 & 91.0 & 2.14 \\
\hline Canned tuna & 59.0 & 117 & 1.98 \\
\hline Canned salmon & NR & 0.00 & 2.03 \\
\hline Other canned fish & NR & 0.00 & 2.00 \\
\hline $\begin{array}{l}\text { Other meat, fish, } \\
\text { or poultry }\end{array}$ & NR & 0.00 & 2.00 \\
\hline $\begin{array}{l}\text { Carbonated } \\
\text { drinks }\end{array}$ & 338 & 135 & 0.40 \\
\hline Orange juice & 188 & 82.6 & 0.44 \\
\hline Tomato juice & 99.5 & 18.9 & 0.19 \\
\hline Pineapple juice & 178 & 97.6 & 0.55 \\
\hline $\begin{array}{l}\text { Other canned } \\
\text { juice }\end{array}$ & 25.4 & 12.7 & 0.50 \\
\hline Evaporated milk & 201 & 276 & 1.37 \\
\hline Powdered milk & 72.9 & 99.9 & 1.37 \\
\hline Whole milk & 0.00 & 0.00 & 0.68 \\
\hline Canned butter & 0.00 & 0.00 & 7.16 \\
\hline Onion & 0.00 & 0.00 & 0.45 \\
\hline $\begin{array}{l}\text { Canned } \\
\text { vegetables }\end{array}$ & NR & 0.00 & 0.80 \\
\hline Baby food & NR & 0.00 & 1.00 \\
\hline Cocoa & 178 & 173 & 0.97 \\
\hline Ramen noodles & 6.07 & 7.6 & 1.25 \\
\hline Candy & NR & 0.00 & 4.00 \\
\hline Total Imported & 2168 & 2661 & \\
\hline Fluids & 1280 & 895 & \\
\hline Solids & 888 & 1766 & \\
\hline $\begin{array}{l}\text { Total Local and } \\
\text { Imported }\end{array}$ & 3490 & 3208 & \\
\hline Fluids & 2326 & 906 & \\
\hline Solids & 1164 & 2302 & \\
\hline
\end{tabular}

\footnotetext{
a. Data from Murai et al. (1958).

b. Includes data from Watt \& Merrill (1963), Burton (1965), Buchanan (1947), and Pennington (1976).

c. Footnotes are in Appendix B.
} 
Table 6 that includes 1978 NMIR data and the 1993/94 data. The numbers of samples that were averaged to derive each of the mean values, as well as the median and range of values, are listed in Appendix B.

The 1978 coconut data have been adjusted for the stage of coconut development for the following reasons. During the 1978 NMIRS, U.S. personnel conducting the survey collected all coconut, Pandanus, breadfruit, other vegetation, and soil samples. All of the coconuts collected on Utirik Island (and the other islands) were assumed to be drinking coconuts. The ${ }^{137} \mathrm{Cs}$ concentration of $0.050 \mathrm{~Bq} \mathrm{~g}^{-1}\left(1.3 \mathrm{pCi} \mathrm{g}^{-1}\right)$ in the coconut samples from Utirik Island was used for the drinking coconut meat value in the dose assessment. A value for copra meat was estimated from this "assumed" drinking coconut meat value and was taken as $0.072 \mathrm{~Bq} \mathrm{~g}^{-1}\left(2 \mathrm{pCi} \mathrm{g}^{-1}\right)$.

As we progressed with our program from 1979 to the present, we have had Marshallese assistants select and classify the coconuts as drinking or copra coconuts. We found that we could differentiate between drinking coconuts and copra coconuts, as selected by the Marshallese staff, by measuring the dry-to-wet ratio of the coconut meat. If the coconut meat dry-to-wet ratio is greater than 0.45 , then the coconuts fall into the copra class, and if the ratio is less than 0.45 , they are classified as drinking coconut.

When we apply these criteria to the coconuts collected in 1978, we find the coconuts collected by U.S. personnel in 1978 were approximately $65 \%$ copra coconuts and $35 \%$ drinking coconuts. Consequently, the concentration of $0.050 \mathrm{~Bq} \mathrm{~g}^{-1}\left(1.3 \mathrm{pCi} \mathrm{g}^{-1}\right)$ used in the 1982 dose assessment was too high for the drinking coconut class because the ${ }^{137} \mathrm{Cs}$ concentration is higher in copra coconuts than in drinking coconuts.

The concentrations of ${ }^{137} \mathrm{Cs}$ in foods from Utirik Atoll, based on all the data from 1993 and 1994, are compared in Table 7 with the data from the 1978 NMIRS that have been adjusted for the drinking/copra stage of development and decay corrected to 1998 (more detailed information for each island is given in Appendix $B$ and $C$ ). The uncorrected values were used in the 1982 preliminary assessment (Robison et al.,
1982). The results for samples collected in 1978 and those collected in 1993 and 1994 are within a factor of 2 for all food products even though there was a much more limited sampling in 1978.

\section{Radionuclides in Marine Foods}

The concentrations of ${ }^{137} \mathrm{Cs},{ }^{90} \mathrm{Sr},{ }^{239+240} \mathrm{Pu}$, and ${ }^{241} \mathrm{Am}$ in fish, crustaceans, invertebrates, marine-eating birds and bird eggs are listed in Table 6 . The data for marine fish, shellfish, and invertebrates resulted from the work conducted at Utirik Atoll during the 1978 NMIRS. The sources of these data are identified in table footnotes in Appendix B.

The ${ }^{137} \mathrm{Cs}$ concentrations are very low in the edible flesh of marine foods identified above. The concentrations of ${ }^{90} \mathrm{Sr},{ }^{239+240} \mathrm{Pu}$, and ${ }^{241} \mathrm{Am}$ in the edible tissues of marine species are also low. Somewhat higher concentrations for these radionuclides are noted in the bones and gut contents of reef fish. Many of the reef fish feed on coral and bottom sediments which still contain low but measurable levels of ${ }^{90} \mathrm{Sr}$, ${ }^{239+240} \mathrm{Pu}$, and ${ }^{241} \mathrm{Am}$ (Noshkin et al., 1987). However, the bones and gut contents of these fish are generally not consumed by the Marshallese.

The marine pathway does not provide a major source of intake of ${ }^{137} \mathrm{Cs},{ }^{90} \mathrm{Sr},{ }^{239+240} \mathrm{Pu}$, and ${ }^{241} \mathrm{Am}$ or any other man-made radionuclides. However, accumulation of naturally occurring ${ }^{210} \mathrm{Po}$ and ${ }^{210} \mathrm{~Pb}$ is high by these organisms (Noshkin et al., 1994).

\section{Diet}

\section{Terrestrial and Marine Food Consumption}

The estimated average intake of local and imported foods used in the dose assessment is a very important parameter; radiological dose scales directly with the total intake of ${ }^{137} \mathrm{Cs}$, which is proportional to the quantity of locally grown foods that are consumed. Therefore, a reasonable estimate of the average daily consumption rate of each food item is essential. The basis of this diet model was the survey of the Ujelang community in 1978 by the Micronesian Legal Services Corporation (MLSC) staff and a Marshallese school teacher on 
Table 7. The mean ${ }^{137} \mathrm{Cs}$ concentration in $\mathrm{Bq} \mathrm{g}^{-1}$ wet weight for Utirik Atoll food products (decay corrected to 1998).

\begin{tabular}{|c|c|c|c|c|c|c|c|c|}
\hline $\begin{array}{l}\text { Time } \\
\text { period }\end{array}$ & $\begin{array}{c}\text { Drinking } \\
\text { coconut } \\
\text { meat }\end{array}$ & $\begin{array}{c}\text { Drinking } \\
\text { coconut } \\
\text { fluid }\end{array}$ & $\begin{array}{l}\text { Copra } \\
\text { meat }\end{array}$ & $\begin{array}{c}\text { Pandanus } \\
\text { fruit }\end{array}$ & Breadfruit & Papaya & Banana & $\begin{array}{c}\text { Total } \\
\text { number of } \\
\text { samples }\end{array}$ \\
\hline \multicolumn{9}{|l|}{ Utirik Island } \\
\hline 1978 NMIRS & $0.023(7)^{\mathrm{a}}$ & $0.0035(7)$ & $0.041(11)$ & $0.037(18)$ & $0.016(2)$ & $0.082(1)$ & $0.013(1)$ & 47 \\
\hline 1993 & $0.017(121)$ & $0.0086(122)$ & $0.022(23)$ & $0.053(17)$ & $0.019(6)$ & $0.054(1)$ & $0.0073(1)$ & 291 \\
\hline \multicolumn{9}{|l|}{ Aon Island } \\
\hline 1978 NMIRS & $0.038(4)$ & $0.0059(4)$ & $0.054(5)$ & $0.049(4)$ & $0.021(1)$ & - & - & 18 \\
\hline 1994 & $0.020(59)$ & $0.011(53)$ & $0.040(2)$ & $0.028(4)$ & $0.013(2)$ & - & - & 120 \\
\hline \multicolumn{9}{|l|}{ Bikrak Island } \\
\hline 1978 NMIRS & $0.013(3)$ & $0.0033(3)$ & $0.020(3)$ & $0.036(10)$ & - & - & - & 19 \\
\hline 1994 & $0.0062(17)$ & $0.0026(15)$ & $0.0082(3)$ & $0.011(5)$ & - & - & - & 40 \\
\hline \multicolumn{9}{|l|}{ Elluk Island } \\
\hline 1978 NMIRS & - & - & - & - & - & - & - & - \\
\hline 1994 & $0.0051(4)$ & $0.0013(4)$ & $0.0035(1)$ & $0.0090(2)$ & - & - & - & 11 \\
\hline
\end{tabular}

a Number of samples in parentheses. 
Ujelang (Robison et al., 1980). We believe that the MSLC survey provides a reasonable basis for estimating dietary intake, and we use the results rather than attempt further speculative refinement. LLNL and independent committees, in concert with local government authorities, with the legal representatives of the people, and with Peace Corps representatives, and anthropologists have endeavored to establish and document pertinent trends, cultural influences, and economic realities - with the hope that our diet estimates may be soundly based.

The diet model we use for estimating the intake of local plus imported foods (IA; imports available) is presented in Tables 6. Data on the $\mathrm{Bq} \mathrm{d}^{-1}$ intake for each food product is listed in Appendix D. The radionuclide concentration in imported foods is assumed to be zero, although very, very low levels from world-wide fallout do exist in some foods. However, their contribution to the dose is negligible.

The IA diet model is the preferred model to use to calculate the doses because it reflects current dietary practices in the Marshall Islands.

A diet based on the consumption of only local foods, (i.e., imported foods unavailable, IUA) is shown in Table 6 and is also based on the MLSC survey. Our observation is that in the Marshall Islands of today this is unrealistic. The demand for imported foods is present, they are considered staples in the diet, and suppliers and commercial transport are also available. Even though re-supply schedules may be somewhat erratic, inventories of imported foods are expected to be such that the total absence of imported foods from the diet is most unlikely.

Support of our IA diet model is found in other estimates of coconut consumption. The current estimate of consumption of coconut meat and fluid in our diet model of about 1 to 1.5 coconuts per day, per person, averaged over a year is consistent with estimates of an average of 0.5 and 1.0 coconuts per day, per person, made by two Marshallese officials with considerable experience in living habits at atolls other than Majuro Atoll (DeBrum, 1985).

Based on data published by Mary Murai in 1954, the average intake of coconut products was drinking coconut fluid, $95 \mathrm{~mL} \mathrm{~d}^{-1}$; copra meat, $48 \mathrm{~g} \mathrm{~d}^{-1}$; and drinking coconut meat, $10 \mathrm{~g} \mathrm{~d}^{-1}$; however, sprouting coconut was not mentioned (Murai, 1954). The total intake is essentially the same as the results of the Ujelang Survey. It might be noted that consumption of local foods in 1954 was higher than today.

Moreover, the Bikini Atoll Rehabilitation Committee (BARC) asked for a survey on coconut consumption by the Bikini community (Bikini Atoll Rehabilitation Committee, 1986). The result of the limited survey was that coconut consumption was about one-third of that indicated in the MLSC diet listed in Table 6. Similarly, in the summary of a survey conducted during July and August of 1967 at Majuro Atoll, the average coconut use was reported to be approximately 0.5 coconut, per day, per person (Domnick and Seelye, 1967). This included young drinking coconuts, old nuts used for grated meat and pressed for small volumes of milk, and sprouting nuts used for the sweet, soft core. Data from Eneu Island show that an average drinking coconut contains $325 \mathrm{~mL}$ of fluid (standard deviation equals $125 \mathrm{~mL}$ ), so that even if the entire average coconut use of 0.5 per day were all drinking nuts, the average intake would be about $160 \mathrm{~g} \mathrm{~d}^{-1}$. This is in agreement with the results from the MLSC survey at Ujelang.

Experience at Enewetak Atoll also supports our model. In past years, coconuts have been brought to Enewetak Atoll from Ujelang Atoll. Sufficient quantities have been available for the average consumption rate to have been 1 coconut per day, per person, if all coconuts were consumed. However, all the coconuts were not consumed, a significant number were fed to pigs or left to decay, and thus the average coconut consumption rate has been less than 1 coconut per person per day (Wilson, 1985). In short, the average coconut consumption rate in our diet model appears to be somewhat higher than in other sources of information we have found, except the BNL report in which estimates were made of food prepared, not food consumed (Naidu et al., 1980).

Another way to evaluate the general validity of a proposed diet model is to determine the total daily intake in terms of mass and calories. A summary of the grams per day $\left(\mathrm{g} \mathrm{d}^{-1}\right)$ intake of solid foods plus milk products and liquids in our diet model compared with average U.S. diets is listed in Table 8. Also listed is the average kilocalories per day $\left(\mathrm{kcal} \mathrm{d}^{-1}\right)$ intake for the diet model when imported foods are both available and unavailable, and for the U.S. 
Table 8. Comparison of the average adult diet model for the Northern Marshall Islands with the average adult diet for the United States.

\begin{tabular}{|c|c|c|c|c|c|}
\hline & \multicolumn{2}{|c|}{$\begin{array}{c}\text { Average adult diet } \\
\text { model for the Northern } \\
\text { Marshall Islands }\end{array}$} & \multicolumn{3}{|c|}{$\begin{array}{l}\text { Average adult diet } \\
\text { for the United States }\end{array}$} \\
\hline & $\begin{array}{l}\text { Imports } \\
\text { available }\end{array}$ & $\begin{array}{c}\text { Imports } \\
\text { unavailable }\end{array}$ & $\begin{array}{l}\text { Yang and } \\
\text { Nelson } \\
\text { (1986) }\end{array}$ & $\underset{\text { (1979) }}{\text { Abraham et al. }}$ & $\begin{array}{l}\text { Rupp } \\
\text { (1980) }\end{array}$ \\
\hline $\begin{array}{l}\text { Food intake, } \mathrm{g} \mathrm{d}^{-1} \\
\text { (wet wt.) }\end{array}$ & 1164 & 1217 & 1066 & - & 1232 \\
\hline Fluid intake, $\mathrm{g} \mathrm{d}^{-1}$ & 2326 & 1002 & 1526 & - & 1351 \\
\hline Caloric intake, kcal d-1 & 3208 & 2004 & 1853 & 1925 & - \\
\hline
\end{tabular}

population from three different sources (Yang and Nelson, 1986; Abraham et al., 1979; Rupp, 1980). The average food intake reported for Japan by Hisamatsu et al. (1987) and by the Japanese Ministry of Health and Welfare is 1253 $\mathrm{g} \mathrm{d}^{-1}$ and $1352 \mathrm{~g} \mathrm{~d}^{-1}$, respectively (Hisamatsu et al., 1987).

The intake of about $1440 \mathrm{~g} \mathrm{~d}^{-1}$, including milk products (1164 g solids $+274 \mathrm{~g}$ milk) in our diet model when imported foods are available, is higher by about 200 to $400 \mathrm{~g} \mathrm{~d}^{-1}$ than the results from the U.S. and Japanese surveys that also include milk and milk products. The 3208 $\mathrm{kcal} \mathrm{d}^{-1}$ in the diet model exceeds the U.S. average by a little more than $1000 \mathrm{kcal} \mathrm{d}^{-1}$. The average recommended allowances for caloric intake range from 2000 to $3200 \mathrm{kcal} \mathrm{d}^{-1}$, and individual recommended allowances from 1600 to $4000 \mathrm{kcal} \mathrm{d}^{-1}$ (Dietary Standard for Canada, 1964; FAO, 1957; Joint FOA, WHO/UNU, 1985; ICRP, 1975; NAS, 1980).

This comparison shows that our diet model, based upon the MLSC survey at Ujelang Atoll, is not seriously at variance with the U.S. and Japanese data for $\mathrm{g} \mathrm{d}^{-1}$ intake or for total daily calories consumed.

A few general conclusions can be drawn from evaluating all of the available data on dietary habits in the Marshall Islands.

1. Coconut consumption is the major source of ${ }^{137} \mathrm{Cs}$ intake in the diet model; the diet model does predict the ${ }^{137} \mathrm{Cs}$ body burden observed in actual whole-body counting of the adult population for Rongelap and Utirik Atolls
(Robison and Sun, 1997). Consequently, the ${ }^{137}$ Cs intake in the model is very close to reality - at least at these atolls.

2. The dietary habits are, to a degree, atollspecific and should be generalized from one atoll to another only when supporting atollspecific data are unavailable.

3. There is still some uncertainty as to what an average diet really is at any atoll.

4. Many factors can affect the average diet over any specific year.

5. Atoll-specific dietary data would improve the dose assessment for each resettlement situation.

\section{Soil Consumption}

The consumption of $100 \mathrm{mg} \mathrm{d}^{-1}$ of dust/soil is built into the diet model for the dose calculations. This accounts for dust from people's hands that could be ingested, and any dust/soil that might inadvertently get in foods.

The dose calculation is made assuming the $100 \mathrm{mg} \mathrm{d}^{-1}$ intake of soil continues everyday of ones life. This is probably a conservative assumption (i.e., maximizing the dose via this route of exposure), especially since gritty, coral sand is not pleasant to chew or consume. Consequently, ingestion of soil is mostly limited to the fine soil dust that is pulverized in the surface soil that can get on one's hands or in foods.

A detailed summary of the Bq per day intake of ${ }^{137} \mathrm{Cs},{ }^{90} \mathrm{Sr},{ }^{239+240} \mathrm{Pu}$, and ${ }^{241} \mathrm{Am}$ for each dietary food item is given in Appendix D. 


\section{Dose Methodology}

Both the potential effective external and internal dose have been calculated for the population on Utirik Island using the available data and information. The sources of exposure and methods of calculation are different for external and internal exposure.

\section{External Exposure}

Estimates of external exposure include both gamma and beta radiation. The method of calculation for each is described below.

\section{Gamma Radiation}

The external exposure calculations for gamma radiation are based on measurements made on Utirik Island in 1993 and 1994, and decay corrected to 1998 . The following arbitrary distribution of time was used to develop the average external exposure for ${ }^{137} \mathrm{Cs}$ for a 1998 resettlement:

1. Ten $\mathrm{h} \mathrm{d}^{-1}$ are spent in the house where the exposure rate is $0.08 \mu \mathrm{R} \mathrm{h}^{-1}$.

2. Nine $\mathrm{h} \mathrm{d}^{-1}$ around the house and village area where the exposure rate is assumed to be $0.15 \mu \mathrm{R} \mathrm{h}^{-1}$ (weighted average of outside house and general village sites).

3. Three $\mathrm{h} \mathrm{d}^{-1}$ in the interior region of the island where the average exposure is $0.47 \mu \mathrm{Rh}^{-1}$.

4. Two $\mathrm{h} \mathrm{d}^{-1}$ on the beach or lagoon where the exposure is at background levels.

Although the selection of this particular time distribution is arbitrary, general discussions with Marshallese people and observations made while we have been in the islands make the selection reasonable.

The external exposure rate in $\mu \mathrm{R} \mathrm{h}^{-1}$ is converted to effective dose rates using a factor of $0.061 \mathrm{mSv} \mathrm{y}^{-1}$ per $\mu \mathrm{R} \mathrm{h}^{-1}$. This conversion is based on data from ICRP Publication 51 (ICRP, 1987) for the conversion to the effective dose equivalent per unit exposure in free air for $662 \mathrm{keV}$ photons. This air conversion is $0.6 \times 10^{-2} \mathrm{~Sv} \mathrm{R}^{-1}$. Data listed in ICRU
Publication 39 are about 0.58 for omnidirectional (isotropic) radiation (ICRU, 1985). Other reports in the literature give results for the conversion factor for wholebody of about 0.57 for an average for male and female (O'Brien, 1980), 0.52 for red bone marrow (Kerr, 1980) which translates to about 0.54 for wholebody, and about 0.62 for wholebody (Williams et al., 1985).

The resultant contributions of ${ }^{137} \mathrm{Cs}$ to the annual average effective dose in the first year of occupancy of various island areas described in the above scenario are:

1. Inside houses- $0.0020 \mathrm{mSv}^{-1}$ $\left(0.20\right.$ mrem y $\left.^{-1}\right)$.

2. Elsewhere in the housing and village area- $0.0034 \mathrm{mSv}^{-1}$ $\left(0.34\right.$ mrem y $\left.^{-1}\right)$,

3. Island interior- $-0.0036 \mathrm{mSv} \mathrm{y}^{-1}$ $\left(0.36 \mathrm{mrem} \mathrm{y}^{-1}\right)$.

The average external effective dose rate attributable to such a living pattern in 1998 on Utirik Island is about $0.0085 \mathrm{mSv} \mathrm{y}^{-1}(0.90 \mathrm{mrem}$ $\mathrm{y}^{-1}$ ). The external background effective dose rate is about $0.22 \mathrm{mSv} \mathrm{y}^{-1}\left(22 \mathrm{mrem} \mathrm{y}^{-1}\right)$.

\section{Beta Radiation}

It is impossible to predict precisely what the beta dose to the skin will be, but it is clear that the "shallow dose" due to both beta particles and external gamma exposure will be only slightly greater than the dose estimated for external gamma whole-body exposure. This higher "shallow dose" will occur primarily to the most exposed parts of the body, usually the arms, lower legs, and feet. The skin is a much less sensitive organ to radiation than other parts of the body; for example, the weighting factor for stochastic risk recommended by the ICRP for skin is 0.01 , compared with 0.20 for gonads, 0.12 for red bone marrow, colon, stomach, and lungs, and 0.05 for breast, bladder, liver, and thyroid (ICRP, 1990). Consequently, the beta contribution to the total effective dose is extremely small. 


\section{Internal Exposure}

\section{Cesium-137}

The conversion from the intake of ${ }^{137} \mathrm{Cs}$ to the dose equivalent for the adult is based upon the ICRP methods described in ICRP Publications 56, 61 (ICRP, 1990; 1991a), which are based on Leggett's model (Leggett, 1986). The biological half-life of ${ }^{137} \mathrm{Cs}$ is determined as a function of mass (i.e., age) by the methods described in Leggett (1986). In a separate report we estimated the comparative doses between adults and children (Robison and Phillips., 1989). The results indicate that the estimated integral effective dose for adults due to ingestion of ${ }^{137} \mathrm{Cs}$ and ${ }^{90} \mathrm{Sr}$ can be used as a conservative estimate for intake beginning at any other age. In this report we calculate only the doses to adults.

\section{Strontium-90}

The model developed by Leggett et al. (1982) is based on the structure and function of bone compartments as generally outlined in the ICRP model (ICRP, 1990). The bone is assumed to be composed of a structural component associated with bone volume, which includes the compact cortical bone, a large portion of the cancellous (trabecular) bone, and a metabolic component associated with bone surfaces. We will not discuss further details of these models, but refer the reader to the original articles and their associated references for additional discussion and clarification (Leggett et al., 1982; Cristy et al., 1984). Doses listed in this paper are calculated from the Leggett model.

\section{Transuranic Radionuclides $\left({ }^{239+240} \mathrm{Pu}\right.$ and ${ }^{241} \mathrm{Am}$ )}

\section{Ingestion}

We calculated the dose equivalent from ingestion of transuranic radionuclides $\left({ }^{239+240} \mathrm{Pu}\right.$ and ${ }^{241} \mathrm{Am}$ ) by ICRP methods (ICRP, 1986, 1988). The amount of ingested plutonium or americium crossing the gut wall to the blood is assumed to be $5 \times 10^{-4}$ for $\mathrm{Pu}$ and $\mathrm{Am}$ in vegetation, and $10^{-5}$ (Harrison et al., 1989) and $5 \times 10^{-4}$ for the fraction of $\mathrm{Pu}$ and Am, respectively, ingested via soil. Of the fraction of $\mathrm{Pu}$ or Am reaching the blood, $45 \%$ is assumed to go to bone and $45 \%$ to the liver (ICRP, 1986,
1993). The biological half-life is $50 \mathrm{y}$ in bone and $20 \mathrm{y}$ in liver for both elements (ICRP, 1986, 1993). The quality factor is 20 for the alpha particles.

\section{Inhalation}

The dose equivalent from inhalation for the transuranic radionuclides is based on the intake determined from the assumptions discussed in the section on Airborne, Respirable Radionuclide Concentrations of this paper and the ICRP new lung model dose methodology (ICRP, 1986, 1990, 1994). The $239+240 \mathrm{Pu}$ and ${ }^{241} \mathrm{Am}$ are considered class $\mathrm{M}$ particles, and the quality factor is 20 for the alpha particles. Other parameters are as described in the ICRP method previously discussed for the ingestion of transuranic radionuclides. The activity-median aerodynamic diameter (AMAD) is assumed to be $1 \mu \mathrm{m}$, which provides a slightly conservative dose estimate (i.e., slightly higher dose) because the observed AMAD was about $2.5 \mu \mathrm{m}$ in the Bikini experiment (Shinn et al., 1997).

\section{Polonium-210, $210 \mathrm{~Pb}$}

The estimated dose from ingestion of natural ${ }^{210} \mathrm{Po}$ and ${ }^{210} \mathrm{~Pb}$ is based on ICRP data and methods (ICRP, 1991a). The weighted committed dose equivalent per unit intake of activity for ${ }^{210} \mathrm{Po}$ is $2.2 \times 10^{-7} \mathrm{~Sv} \mathrm{~Bq}^{-1}$ and for ${ }^{210} \mathrm{~Pb}$ is $1 \times 10^{-6} \mathrm{~Sv} \mathrm{~Bq}^{-1}$.

\section{Body Weights and Biological Half-Life of ${ }^{137} \mathrm{Cs}$}

Data from Brookhaven National Laboratory (BNL) have been summarized to determine the body weights of the Marshallese people (Conard et al., 1959, 1960, 1963, 1975; Miltenberger et al., 1980a \& b). The average adult male body weight is $72 \mathrm{~kg}$ for Bikini, $71 \mathrm{~kg}$ for Enewetak and $69 \mathrm{~kg}$ for Utirik. We have used $70 \mathrm{~kg}$ as the average male body weight in our dose calculations. The average biological half-life for the long-term compartment for ${ }^{137} \mathrm{Cs}$ in adults is listed as 110 $\mathrm{d}$ in ICRP (1990) and NCRP (1977). This is consistent with data obtained by BNL on the half-time of the long-term compartment in Marshallese (Miltenberger et al., 1981; Miltenberger and Lessard, 1987). The distribution of biological half-life in 23 Marshallese adult males is lognormal with a median of $115 d$, a mean of $119 d$, and a range of 
76-178 d. We used the $110 \mathrm{~d}$ half-life because it is based on a much larger sample population and the difference between it and the $115 \mathrm{~d}$ halflife observed in 23 Marshallese males is minimal.

\section{Uncertainty Analysis}

Using methods previously described (NRC, 1994; Bogen, 1995), detailed characterizations of uncertainty and interindividual variability were obtained for updated estimates of potential dose and risk at another U.S. nuclear test site, Bikini Atoll (Bogen et al., 1997). The relative values of all of the parameters used for the Bikini dosimetry analysis were very similar to those pertaining to Utirik, so results from the Bikini uncertainty/variability characterization were applied directly to a dose assessment beginning in 1998 for Utirik, to obtain 95 percent confidence limits $(95 \% \mathrm{CL})$ on the distributions of: (1) uncertainty in population-average 70-y Utirik dose, $\overline{D(70)}$; (2) interindividual variability on the expected value of 70-y Utirik dose, $\langle D(70)\rangle$; and (3) variability in expected 1-y maximum dose, $\operatorname{Max}(\langle D(1)\rangle)$. Predicted population risk $N$ (the number of falloutinduced cancer fatalities) necessarily depends on the size of the population, $n$, and age distribution of the Utirik population involved. We calculated $N$ beginning in 1998 under an imported-foods-available dietary model for $n=$ 300,500 , or 1000 . Under these assumptions, the expected number $\langle N\rangle$ of cancer deaths was calculated, as well as the probability of zero cases, $p_{0}=\operatorname{Prob}(N=0)$. The $N$-distribution was approximated as previously described (NRC, 1994; Bogen, 1995), treating $N$ as being compound-Poisson distributed with the uncertain parameter $N \times \bar{R}$, where $\bar{R}=$ the population-average value of individual risk $=$ $Q \times \overline{D(70)}$, and where $Q$ specifies uncertain radiogenic cancer potency defined as total cancer (leukemia + nonleukemia) mortality risk per unit dose. Evaluation of $N$ thus required distributions characterizing uncertainty in $Q$ and $\overline{D(70)}$.

The uncertainty distribution for $\overline{D(70)}$ on
Utirik was estimated as the product of its expected value, $\langle D(70)\rangle$, and the normalized uncertain variate $D_{B}(70) /\left\langle D_{B}(70)\right\rangle$, where $D_{\mathrm{B}}$ refers to dose on Bikini calculated as previously described (Bogen et al., 1997).

Based on the BEIR V (NRC, 1990) prediction of total cancer (leukemia + nonleukemia) fatalities for males and females likely to be caused by chronic low-LET radiation exposure, and associated analysis of statistical and modelrelated errors, it was assumed that radiogenic cancer potency $Q_{b}$ is approximately lognormally distributed with expectation and geometric standard deviation $\left(\mathrm{SD}_{\mathrm{g}}\right)$ equal to $0.008 \mathrm{mSv}^{-1}$ and 0.5064 (unitless), respectively, for a cohort resettling Utirik at birth. The value of $0.008 \mathrm{mSv}^{-1}$ is the BEIR V (NRC, 1990) recommended population-weighted average value of $0.008 \mathrm{mSv}^{-1}$ for acute low-LET radiation exposure, divided by the approximate factor of two recommended as an adjustment for estimating risk due to cumulative chronic exposure, and multiplied by a second approximate factor of two recommended as an adjustment for estimating risk associated with exposures specifically during childhood (given that a disproportionate amount of cumulative dose to Utirik resettlers would occur during the earlier years post resettlement, due to radiological decay of ${ }^{137} \mathrm{Cs}$ and ${ }^{90} \mathrm{Sr}$ ). Because the latter factor of two would not apply to adults accompanying infants and youth, $Q_{\mathrm{b}}$ was assumed to pertain to a fraction $f$ of the population, and $Q_{\mathrm{b}} / 2$ was assumed to pertain to $100(1-f) \%$ of the resettling population. $\mathrm{SD}_{\mathrm{g}}$ was estimated by the method of moments assuming, based on the BEIR V analysis, that the $90 \%$ upper confidence limit on $Q_{b}$ is $\sim 2.3$ times its median value. Based on the likelihood that there would be a high proportion of infants and children among Utirik residents, the fraction $f$ was assumed to be 0.5 . Overall potency $Q$ was thus modeled as $Q_{b}$ and $Q_{b} / 2$ with equal likelihood, without explicit consideration of the chance that true fallout-related risk on Utirik may be zero in view of current fundamental uncertainties pertaining to radiation carcinogenesis. 


\section{Results}

\section{Dose Calculations}

The estimated maximum annual and integral effective dose for people resettling Utirik Island are calculated using our diet model, the average radionuclide concentrations in locally grown foods (the global fallout concentrations of ${ }^{137} \mathrm{Cs}$ in foods is included), the average biological removal rates and depositions for the radionuclides in organs or the whole body, and the average external dose rates. The maximum annual effective dose rate is defined as the dose rate in that year when the sum of the internal dose and the external gamma dose is at maximum. In other words, using the average value of all parameters in the dose model and our diet model, the annual effective dose for any other year would be less than the maximum annual effective dose we present. The 30-, 50-, and 70-y integral effective doses are calculated with year 1 being 1998 .

Doses are presented for two cases: imported foods available (IA) and imported foods unavailable (IUA). In our diet model for IA, about $60 \%$ of the diet is made up of imported foods, and even this may be low. Imported foods seem now to be established in the diet and the culture. The total caloric intake is 3208 calories per day. The doses listed under the case "IUA" are calculated assuming no imported foods are available, and that only local foods are consumed over the entire lifetime of the people's residence on Utirik Island. As noted in the Data Base Section on Diet, our observations lead us to conclude that the latter case is unrealistic over any extended period of time and highly conservative. Nevertheless, it is presented here so that the reader may apply different assumptions or use the results of future observations to develop an apportioned dose estimate. The IUA diet that resulted from the summary data from the Ujelang survey leads to a total intake of 1392 calories. This is not a sustaining number of calories, and we have increased the total intake to 2004 calories per day, which is a factor of 1.4 higher than the Ujelang diet survey value. The radionuclide intake is also increased by a factor of 1.4 so that the doses listed in this paper for IUA diet are based on this increased caloric intake.
The maximum annual organ equivalent dose and the effective dose when imported foods are available are listed in Table 9. The maximum annual organ equivalent dose rates for IA range from 0.030 to $0.045 \mathrm{~Sv} \mathrm{y}^{-1}$ (3.0 to 4.5 mrem $\mathrm{y}^{-1}$ ) from all exposure pathways. About $0.0085 \mathrm{mSv}(0.85 \mathrm{mrem})$ of this dose is from external gamma exposure, while most of the remainder is from ingestion pathways. The maximum effective dose rate is $0.037 \mathrm{mSv} \mathrm{y}^{-1}$ $\left(3.7 \mathrm{mrem}^{-1}\right)$. The maximum annual effective dose rate for the IUA diet is $0.098 \mathrm{mSv} \mathrm{y}^{-1}$.

The 30-, 50-, and 70-y integral effective dose for residents of Utirik Island, for IA, are listed in Table 10. The doses are presented by pathway and radionuclide so the contribution of each pathway and nuclide can be evaluated. The 30-, $50-$, and $70-y$ integral effective doses are 0.84 $\mathrm{mSv}$ (84 mrem), $1.2 \mathrm{mSv}$ (120 mrem), and 1.4 $\mathrm{mSv}$ (140 mrem), respectively. The same data for the local foods only diet (IUA) are listed in Table 11 , and the 30-, 50-, and 70-y doses are $2.3 \mathrm{mSv}$ (230 mrem), $3.1 \mathrm{mSv}$ (310 mrem), and $3.7 \mathrm{mSv}$ (370 mrem), respectively. The doses calculated in this report are less than those calculated in 1982, if decayed to the same date, (Robison et al., 1982) because of the concentration now used for drinking coconut and copra meat versus that used in 1982, and because the internal gamma dose calculation now accounts for shielding by buildings, etc. In 1982 we used the average open-air gamma exposure with no adjustments for shielding and the amount of time people spent in various locations.

Since that time, we have made specific measurements inside and outside of houses and around the village area at both Bikini and Rongelap to define more precisely the reduction in exposure from buildings and crushed coral.

The contribution of the various exposure pathways is listed in Table 12. Using the $50 \mathrm{y}$ integral dose as an example, the terrestrial food chain accounts for about $74 \%$ of the estimated dose, of which most is due to ${ }^{137} \mathrm{Cs}$. The external gamma exposure contributes about $22 \%$, which is due entirely to ${ }^{137} \mathrm{Cs}$, and all of the other 
Table 9. The maximum annual organ equivalent dose and effective dose in $\mathrm{mSv}^{-1}$ for Utirik Island residents.

\begin{tabular}{|c|c|c|c|c|c|c|}
\hline \multirow[b]{3}{*}{ Organ } & \multirow{3}{*}{$\begin{array}{l}\text { Weight } \\
\text { factor }\end{array}$} & \multicolumn{5}{|c|}{ Dose equivalent rate, $\mathrm{mSv}^{\mathbf{- 1}}$} \\
\hline & & \multirow{2}{*}{$\begin{array}{l}\text { External } \\
\text { gamma }\end{array}$} & \multicolumn{2}{|c|}{ Internal } & \multicolumn{2}{|c|}{ Total $^{\mathbf{a}}$} \\
\hline & & & Ingestion & Inhalation & Organ & Effective \\
\hline \multicolumn{7}{|c|}{ Imported Foods Available } \\
\hline Bone marrow & 0.12 & 0.0085 & 0.032 & 0.00011 & 0.041 & 0.037 \\
\hline Bone surface & 0.01 & 0.0085 & 0.036 & 0.0012 & 0.045 & \\
\hline Gonads & 0.20 & 0.0085 & 0.029 & 0.000016 & 0.037 & \\
\hline Lungs & 0.12 & 0.0085 & 0.026 & 0.00018 & 0.034 & \\
\hline Breast & 0.05 & 0.0085 & 0.023 & 0.0000033 & 0.031 & \\
\hline Thyroid & 0.05 & 0.0085 & 0.026 & 0.0000033 & 0.035 & \\
\hline Liver & 0.05 & 0.0085 & 0.028 & 0.00026 & 0.036 & \\
\hline Colon & 0.12 & 0.0085 & 0.029 & 0.0000036 & 0.037 & \\
\hline Stomach & 0.12 & 0.0085 & 0.027 & 0.0000033 & 0.036 & \\
\hline Bladder & 0.05 & 0.0085 & 0.029 & 0.0000033 & 0.037 & \\
\hline Esophagus & 0.05 & 0.0085 & 0.027 & 0.0000033 & 0.035 & \\
\hline Skin & 0.01 & 0.0085 & 0.022 & 0.0000033 & 0.030 & \\
\hline Remainder & 0.05 & 0.0085 & 0.028 & 0.0000033 & 0.036 & \\
\hline \multicolumn{7}{|c|}{ Imported Foods Unavailable } \\
\hline Bone marrow & 0.12 & 0.0085 & 0.10 & 0.00011 & 0.11 & 0.098 \\
\hline Bone surface & 0.01 & 0.0085 & 0.11 & 0.0012 & 0.12 & \\
\hline Gonads & 0.20 & 0.0085 & 0.092 & 0.000016 & 0.10 & \\
\hline Lungs & 0.12 & 0.0085 & 0.082 & 0.00018 & 0.091 & \\
\hline Breast & 0.05 & 0.0085 & 0.073 & 0.0000033 & 0.081 & \\
\hline Thyroid & 0.05 & 0.0085 & 0.084 & 0.0000033 & 0.093 & \\
\hline Liver & 0.05 & 0.0085 & 0.088 & 0.00026 & 0.097 & \\
\hline Colon & 0.12 & 0.0085 & 0.091 & 0.0000036 & 0.10 & \\
\hline Stomach & 0.12 & 0.0085 & 0.087 & 0.0000033 & 0.095 & \\
\hline Bladder & 0.05 & 0.0085 & 0.091 & 0.0000033 & 0.10 & \\
\hline Esophagus & 0.05 & 0.0085 & 0.084 & 0.0000033 & 0.093 & \\
\hline Skin & 0.01 & 0.0085 & 0.070 & 0.0000033 & 0.078 & \\
\hline Remainder & 0.05 & 0.0085 & 0.090 & 0.0000033 & 0.098 & \\
\hline
\end{tabular}

a The total dose may vary in the second decimal place due to rounding. 
Table 10. The 30-, 50-, and 70-y integral effective dose for Utirik Island residents for a diet including imported foods (Imports Available, IA).

\begin{tabular}{|c|c|c|c|}
\hline & \multicolumn{3}{|c|}{ Integral effective dose, $\mathrm{mSv}$} \\
\hline & $30 y$ & $50 y$ & $70 \mathrm{y}$ \\
\hline External & 0.19 & 0.27 & 0.31 \\
\hline \multicolumn{4}{|l|}{ Internal } \\
\hline${ }^{137} \mathrm{Cs}$ & 0.62 & 0.86 & 1.0 \\
\hline${ }^{90} \mathrm{Sr}$ & 0.016 & 0.023 & 0.027 \\
\hline${ }^{239+240} \mathrm{Pu}$ & 0.0011 & 0.0028 & 0.0051 \\
\hline${ }^{241} \mathrm{Am}$ & 0.0018 & 0.0042 & 0.0074 \\
\hline \multicolumn{4}{|l|}{ Inhalation } \\
\hline${ }^{239+240} \mathrm{Pu}$ & 0.0035 & 0.0081 & 0.012 \\
\hline${ }^{241} \mathrm{Am}$ & 0.0028 & 0.0060 & 0.0084 \\
\hline Total $^{\mathrm{a}}$ & 0.84 & 1.2 & 1.4 \\
\hline
\end{tabular}

a The total dose may vary in the second decimal place due to rounding.

Table 11. The 30-, 50-, and 70-y integral effective dose for Utirik Island residents for a diet of only local foods (Imports Unavailable, IUA).

\begin{tabular}{|c|c|c|c|}
\hline & \multicolumn{3}{|c|}{ Integral effective dose, $\mathrm{mSv}$} \\
\hline & $30 \mathrm{y}$ & $50 y$ & $70 y$ \\
\hline External & 0.19 & 0.27 & 0.31 \\
\hline \multicolumn{4}{|l|}{ Internal } \\
\hline${ }^{137} \mathrm{Cs}$ & 2.0 & 2.7 & 3.2 \\
\hline${ }^{90} \mathrm{Sr}$ & 0.066 & 0.096 & 0.12 \\
\hline${ }^{239+240} \mathrm{Pu}$ & 0.0058 & 0.014 & 0.026 \\
\hline${ }^{241} \mathrm{Am}$ & 0.0039 & 0.0093 & 0.016 \\
\hline \multicolumn{4}{|l|}{ Inhalation } \\
\hline $239+240 \mathrm{Pu}$ & 0.0035 & 0.0081 & 0.012 \\
\hline${ }^{241} \mathrm{Am}$ & 0.0028 & 0.0060 & 0.0084 \\
\hline Total $^{\mathrm{a}}$ & 2.3 & 3.1 & 3.7 \\
\hline
\end{tabular}

a The total dose may vary in the second decimal place due to rounding. 
Table 12. The 30-, 50-, and 70-y integral effective dose for each exposure pathway at Utirik Atoll when imported foods are available.

\begin{tabular}{llll}
\hline & \multicolumn{3}{c}{ Effective integral dose, $\mathbf{~} \mathbf{S v}$} \\
\cline { 2 - 4 } Pathway & $\mathbf{3 0} \mathbf{~}$ & $\mathbf{5 0 ~ \mathbf { y }}$ & $\mathbf{7 0 ~ \mathbf { ~ }}$ \\
\hline External gamma & 0.19 & 0.27 & 0.31 \\
Terrestrial food & 0.64 & 0.89 & 1.1 \\
Marine food & 0.0032 & 0.0055 & 0.0080 \\
Cistern and ground water & 0.0021 & 0.0030 & 0.0036 \\
Inhalation & 0.0063 & 0.014 & 0.020 \\
& & & 1.4 \\
\hline
\end{tabular}

a The total dose may vary in the second decimal place due to rounding.

pathways and radionuclides contribute about $4 \%$. The marine food chain and the ground and cistern water pathways contribute the least to the estimated dose.

\section{Uncertainty and Risk Analysis}

The distribution characterizing interindividual variability in $\operatorname{Max}(\langle D(1)\rangle)$ (the maximum value of expected 1-y effective integral doses, regardless of occurrence year) that was obtained in a previous uncertainty/variability analysis pertaining to Bikini (see Table 4 and Fig. 3 of Bogen et al., $1997)$ indicates that the $95 \% \mathrm{CL}$ on variability in $\operatorname{Max}(\langle D(1)\rangle)$ on Utirik are within a factor of 3 of its population-average value $(0.037 \mathrm{mSv})$.
Likewise, the $95 \% \mathrm{CL}$ on variability in $\langle D(t)\rangle$

(expected effective integral dose) and on uncertainty in $D(t)$ (population-average effective integral dose), both as functions of time post 1998, $t$, are estimated to lie within factors of $\sim 2.5$ and $\sim 2$, respectively, of their common mean value $(1.4 \mathrm{mSv})$, and are furthermore essentially independent of $t$ (particularly for $t>5 \mathrm{y}$ ) (see Table 4 and Fig. 4 of Bogen et al., 1997). Based on the Utirik described above starting in 1998, expected population risk $\langle N\rangle$ was estimated to be $0.025,0.042$, or 0.084 cases respectively for population size (n) of 300,500 , or 1000 residents, respectively. The corresponding probability of zero deaths, $p_{0}=\operatorname{Prob}(N=0)$, obtained for each resettlement scenario was $98 \%(n=300), 96 \%(n$ $=500)$, or $92 \%(n=1000)$.

\section{Discussion}

The estimated background dose for people living in the Marshall Islands is about $1.4 \mathrm{mSv}$ $\mathrm{y}^{-1}$ as listed in Table 1 . The population average, maximum annual dose from Utirik Island from weapons-related radionuclides is $0.037 \mathrm{mSv} \mathrm{y}^{-1}$. This man-made component can be put in perspective by adding it to the Marshall Island background dose and comparing this combined total dose (background plus weapons-related) to the average background dose received by residents of the United States and Europe. The results are shown in Figure 7. The total annual dose, background plus weapons-related, at Utirik Island is $1.5 \mathrm{mSv}$, which is about one half of the average background dose in the United States, and about $60 \%$ of the average background dose for European citizens. In Figure 8 we show a similar comparison for the dose over a 50 y period. The difference is even greater here because of the decay of ${ }^{137} \mathrm{Cs}$ over the $50 \mathrm{y}$ period.

The $0.037 \mathrm{mSv} \mathrm{y}^{-1}$ weapons-related dose in 1998 is about $2.5 \%$ of the Marshall Island 


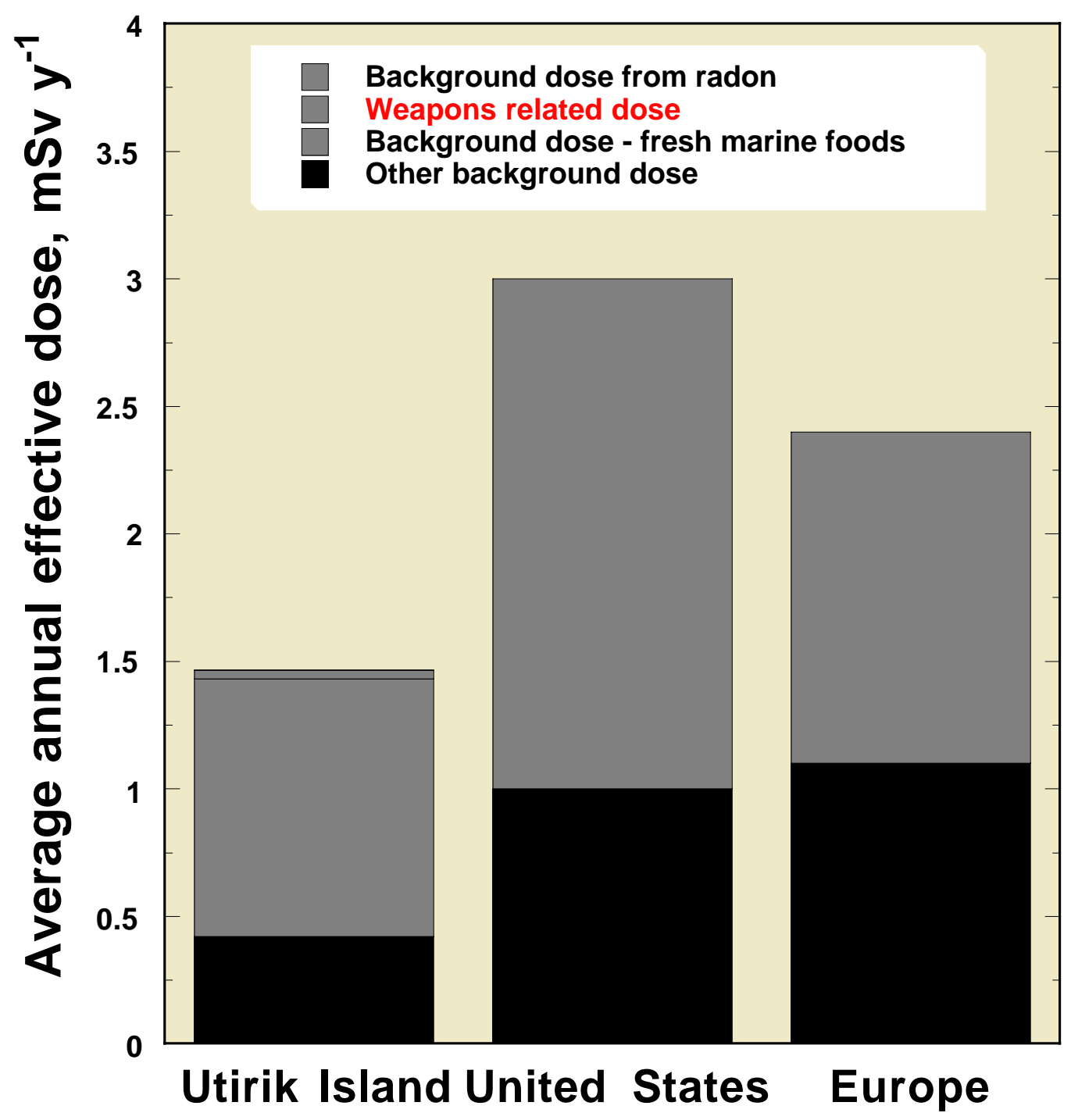

Figure 7. The total effective dose on Utirik Island compared with the background effective dose in the United States and Europe showing the various sub components making up the total doses. 


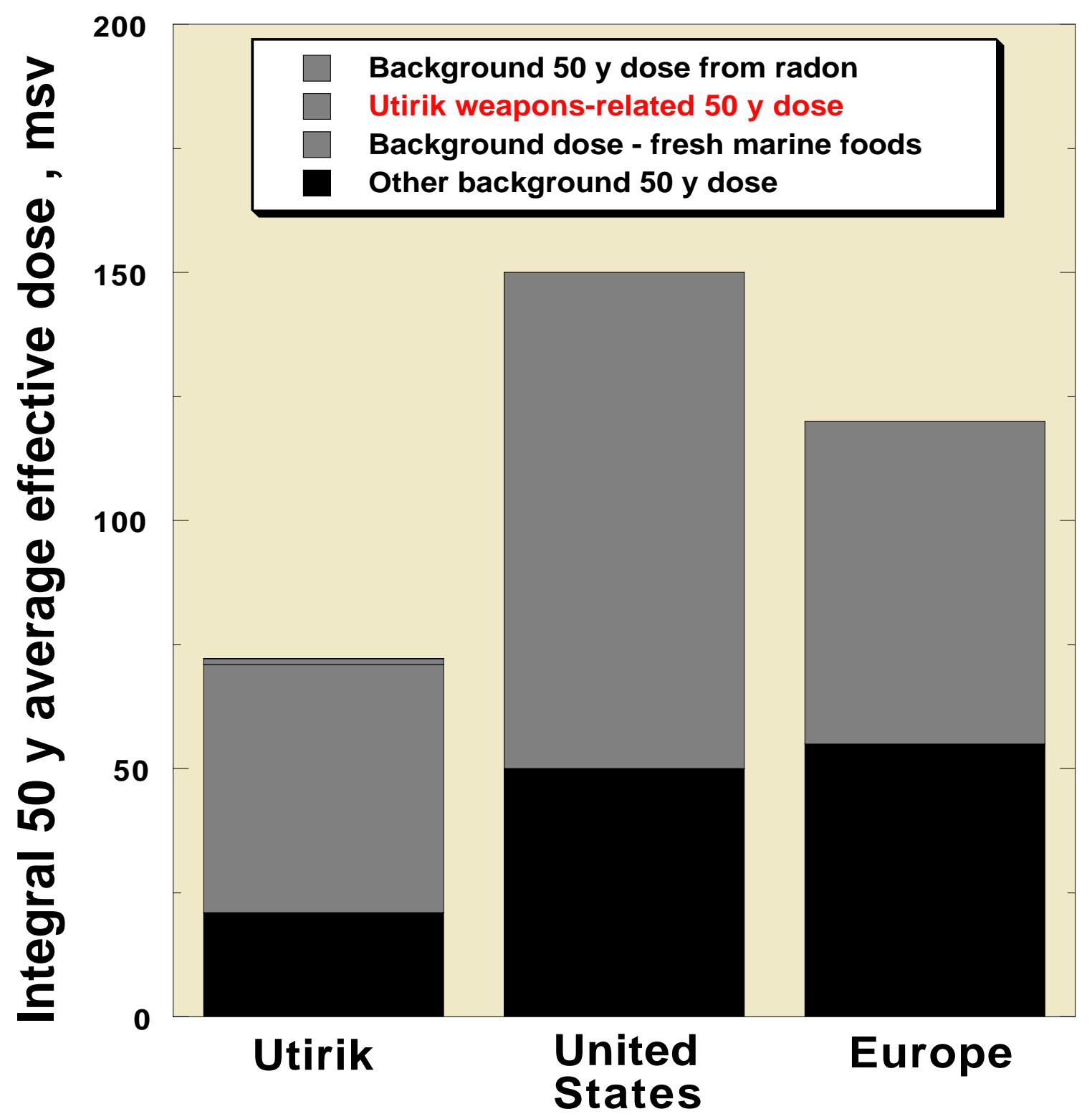

Figure 8. The total integral $50 \mathrm{y}$ effective dose at Utirik Island compared with the effective $50 \mathrm{y}$ integral background dose in the United States and Europe. 
background dose. The weapons-related portion of the total dose is ever declining after 1998 whereas the background portion of the total dose remains constant. Consequently, the weapons-related dose in subsequent years will contribute a progressively smaller percentage of the total dose.

For example, the integral dose over a $50 \mathrm{y}$ period (1998-2068) for the weapons-related portion of the total dose at Utirik is $1.2 \mathrm{mSv}$ (Table 10) whereas the sum of the background dose over $50 \mathrm{y}$ is $71 \mathrm{mSv}$. Over a $50-\mathrm{y}$ period the weapons-related component is only $1.7 \%$ of the background dose, and over a 70-y period is $1.4 \%$. Thus, the weapons-related dose is $2.5 \%$ of the background dose in 1998, but is $1.4 \%$ of the background dose over a 70-y period due to the continuing radiological decay of ${ }^{137} \mathrm{Cs}$.

Moreover, we continually see ${ }^{137} \mathrm{Cs}$ in the groundwater at all contaminated atolls; the turnover time of the groundwater is about $5 \mathrm{y}$. The ${ }^{137} \mathrm{Cs}$ can only get to the groundwater by leaching through the soil column when a portion of the soluble fraction of ${ }^{137} \mathrm{Cs}$ inventory in the soil is transported to the groundwater when rainfall is heavy enough to cause recharge of the acquifer. This process is causing a loss of ${ }^{137} \mathrm{Cs}$ out of the root zone of the plants that provides an environmental loss constant $\left(\lambda_{\text {env }}\right)$ in addition to radiological decay $\lambda_{\text {rad }}$. Consequently, there is an effective rate of loss, $\lambda_{\text {eff }}=\lambda_{\text {rad }}+\lambda_{\text {env }}$ that is the sum of the radiological and environmental-loss decay constants. We have had, and continue to have, a vigorous program to determine the rate of the environmental loss process. What we do know at this time is that the loss of ${ }^{137} \mathrm{Cs}$ over time is greater than the estimated based on only radiological decay.

\section{${ }^{137}$ Cs}

The "environmental data/model" dose assessment approach was evaluated by comparing our estimates of the ${ }^{137} \mathrm{Cs}$ body burden (i.e., dose) in people residing on Rongelap and Utirik Atolls using our environmental data, the domestic models and methods outlined in this paper, and three diet models with the actual ${ }^{137} \mathrm{Cs}$ whole-body measurements conducted by BNL (Robison and Sun, 1997). The LLNL diet model predicts very closely the results of the whole-body measurements over an 8-y period at Rongelap Atoll. Two other proposed diet models lead to estimated body burdens far in excess of those observed by whole-body measurements. Results from Utirik Atoll are similar in that the LLNL diet model predicts actual observation. Other diet models, and especially those based on the consumption of only local foods, greatly overestimate the ${ }^{137} \mathrm{Cs}$ in the body relative to BNL's direct measurement data. A more detailed analysis of this validation is given in Robison and Sun (1997).

\section{9+240 Pu}

The Rongelap people, prior to their relocation in 1985, had been living on Rongelap Island for about $30 \mathrm{y}$ subsequent to the fallout from BRAVO where the plutonium concentration in the surface soil is about $0.11 \mathrm{~Bq} \mathrm{~g}^{-1}$.

The estimated effective doses from plutonium based on the concentrations in food, soil and air using the environmental data/model approach are very similar to those calculated by BNL based on the analysis of plutonium in urine of the Rongelap people (Sun, 1992). These two very independent methods are in excellent agreement on the magnitude of the dose from the transuranic radionuclides. The estimated average committed effective dose for 50-y residence at Rongelap Island from plutonium based on environmental data and models is $0.26 \mathrm{mSv}(0.10 \mathrm{mSv} 50-\mathrm{y}$ integral effective dose) (Robison et al, 1994). The value of $0.40 \mathrm{mSv}$ committed effective dose from urine analyses is based on the detection limit of the analytical method used for detection of plutonium in urine. The median value for plutonium in the urine of all the people analyzed is below this detection limit value. Consequently, both methods indicate that the effective committed dose from plutonium at Rongelap Island is below $0.40 \mathrm{mSv}$ for residence between 30 and $50 \mathrm{y}$.

Another comparison to put the estimated weapons-related dose at Utirik in perspective is given in Table 13. The integral dose over 50 years from weapons-related radionuclides is compared with various standards that are either adopted or proposed (ICRP, 1991b; NCRP, 1993; NRC, 1997; EPA, 1994). 
Table 13. Comparison of the 50-y integral dose from weapons-related radionuclides at Utirik Atoll to the $1 \mathrm{mSv}, 0.25 \mathrm{mSv}$, and $0.15 \mathrm{mSv}$ guidelines summed over $50 \mathrm{y}$.

\begin{tabular}{|c|c|c|c|c|}
\hline & $\begin{array}{c}\text { Utirik } \\
\text { weapons-related }\end{array}$ & $\begin{array}{c}1 \mathrm{mSv} \mathrm{y}^{-1} \\
(\times 50 \mathrm{y})\end{array}$ & $\begin{array}{c}0.25 \mathrm{mSv} \mathrm{y}^{-1} \\
(\times 50 \mathrm{y})\end{array}$ & $\begin{array}{c}0.15 \mathrm{mSv} \mathrm{y}^{-1} \\
(\times 50 \mathrm{y})\end{array}$ \\
\hline Integral $50 \mathrm{y}$ dose, $\mathrm{mSv}$ & 1.2 & 50 & 12.5 & 7.5 \\
\hline
\end{tabular}

Each of the adopted or proposed guidance values represents that dose that is allowable annually. Consequently, the weapons-related $50-y$ dose can be compared to the standards by multiplying the annual dose for the standard in $\mathrm{mSv} \mathrm{y}^{-1}$ by $50 \mathrm{y}$ as shown in Table 13. The estimated dose at Utirik Atoll is below all of the proposed guidelines.

An analysis of uncertainty and interindividual variability in estimated doses conducted for Utirik Island indicates that $95 \% \mathrm{CL}$ on both uncertainty and variability in predicted Utirik dose lie within a factor of $\sim 3$ of the corresponding best estimate of dose.

Accounting explicitly for uncertainties in predicted dose and in radiogenic cancer potency, it was determined that it is quite $(>90 \%)$ certain that no cancer deaths will arise due to residency on Utirik.

It is clear that the weapons-related dose from man-made radiation on Utirik Atoll is a small fraction of any one of the adopted or proposed guidance values. The Utirik 50-y integral dose ranges from $2.4 \%$ to $16 \%$ of the various guidance dose levels.

\section{Conclusions}

The radiological dose on Utirik Atoll today from weapons-related radionuclides is very low and of no consequence to the health detriment of the population. The Utirik people can live on their atoll without concern about radiological exposure and enjoy life on their islands.

\section{Acknowledgment}

Work performed under the auspices of the U.S. Department of Energy at Lawrence
Livermore National Laboratory under contract W-7405-Eng-48.

\section{References}

Abraham, S., M. D. Carroll, C. L. Johnson, and C. M. Dresser Villa (1979), Caloric and Selected Nutrient Values for Persons 1-74 Years of Age: First Health and Nutrition Examination Survey United States 1971-1974, U.S. Department of Health, Education and
Welfare, DHEW Pub. No. (DHS) 791657, Series 11, No. 209.

Bikini Atoll Rehabilitation Committee

(BARC) (1986), Report No. 4, Status

March 31, 1986, Submitted to the U.S.

Congress, House and Senate

Committees on Interior Appropriations, pursuant to House Report 99-450. 
Bogen, K. T., and R. C. Spear (1987), "Integrating Uncertainty and Interindividual Variability in Environmental Risk Assessment," Risk Analysis 7, 427-436.

Bogen, K. T. (1995), Methods to approximate joint uncertainty and variability in risk. Risk Anal. 15, 411-419.

Bogen, K. T., C. L. Conrado, and W. L. Robison (1997), Uncertainty and variability in updated estimates of potential dose and risk at a U.S. nuclear test site-Bikini Atoll. Health Phys. 73, 115-126.

Buchanan, J. R. C. (1947), A Guide to Pacific Island Dietaries, South Pacific Board of Health, Sava, Fiji.

Burton, B. (1965), The Heinz Handbook of Nutrition, $2^{\text {nd }}$ ed. (Heinz, (H.J.) Company, McGraw-Hill, New York, NY.

Conard, R. A., and et al. (1963), Medical Survey of Rongelap People Eight Years after Exposure to Fallout, Brookhaven National Laboratory, Upton, NY, BNL780.

Conard, R. A., H. E. MacDonald, A. Lowery, L. M. Meyer, W. W. Sutow, B. S. Blumberg, J. W. Hollingsworth, H. W. Lyon, W. H. Lewis Jr., A. A. Jaffee, M. Eicher, D. Potter, L. II, E. Riklon, J. Iaman, and J. Helkew (1960), Medical Survey of Rongelap People Five and Six Years after Exposure to Fallout, Brookhaven National Laboratory, Upton, NY, BNL-609.

Conard, R. A., J. S. Robertson, L. M. Meyer, W. W. Sutow, W. Wollins, A. Lowery, H. C. Brschel Jr., J. M. Barton, M. Goldman, H. Hechter, M. Eicher, R. K. Carver, and P. W. Potter (1959), Medical Survey of Rongelap People, March 1958, Four Years after Exposure to Fallout, Brookhaven National Laboratory, Upton, NY, BNL-534.
Conard, R. A., K. Knudsen, B. M. Dobyns, and et al. (1975), A Twenty-year Review of Medical Findings in a Marshallese Population Accidentally Exposed to Radioactive Fallout, Brookhaven National Laboratory, Upton, NY, BNL50424.

Crase, K. W., P. H. Gudiksen, and W. L. Robison (1982), " $\beta$ - and $\gamma$-Comparative Dose Estimates on Enewetak Atoll," Health Physics 42, 559-564.

Cristy, M. R., W. Leggett, D. E. Dunning Jr., and K. F. Eckerman (1984), AgeDependent Dose-Conversion Factors for Selected Bone-Seeking Radionuclides, Nuclear Regulatory Commission, NUREG/CR-3535, ORNL/TM-8929.

DeBrum, R. (1985), Marshall Islands Liaison Representative to U.S. Department of Energy, and O. DeBrum, Chief Secretary of the Marshall Islands, personal communication.

“Dietary Standard for Canada," (1964), Can. Bull. Nutr. 6 1-76.

Dominick, C., and M. Seelye (1967), "Subsistence Patterns Among Selected Marshallese Villagers," Laura Report, L. Mason, ed., University of Hawaii, Honolulu, HI, 1-41.

Environmental Protection Agency (EPA) (1994), Federal Register 40 CFR, Part 196, Subpart A.

Food and Agricultural Organization of the United Nations (FAO) (1957), Calorie Requirements, FAO Nutritional Studies No. 15, Rome.

Gudiksen, P. H., T. R. Crites, and W. L. Robison (1976), External Dose Estimated for Future Bikini Atoll Inhabitants, Lawrence Livermore National Laboratory, Livermore, CA, UCRL51879, Rev. 1. 
Harrison, J. D., G. P. L. Naylor, and J. W. Stather (1989), Gastrointestrial Absorption of Plutonium and Americium in Rats and Guinea Pigs after Ingestion of Dusts from the Former Nuclear Weapons Test Site at Marolinja: Implication for Human Exposure, Radiation Protection Board, Chilton, Didcot, Oxon, NRPB-M196.

Hisamatsu, S., Y. Takizawa, and T. Abe (1987), "Fallout 3H Ingestion in Akita, Japan," Health Physics 53, 287-293.

International Commission on Radiation Units and Measurements (ICRU) (1985), Determination of Dose Equivalents Resulting from External Radiation Sources, International Commission on Radiation Units and Measurements, Bethesda, MD, Report 39.

International Commission on Radiological Protection (ICRP) (1986), The Metabolism of Plutonium and Related Compounds, Pergamon Press, Oxford, UK, ICRP Pub. 48.

International Commission on Radiological Protection (ICRP) (1987), Data for Use in Protection Against External Radiation, Pergamon Press, Sutton, Surry, UK, ICRP Pub. 51.

International Commission on Radiological Protection (ICRP) (1988), Limits for Intakes of Radionuclides by Workers: An Addendum, Pergamon Press, New York, NY, ICRP Pub. 30, Part 4.

International Commission on Radiological Protection (ICRP) (1990), AgeDependent Doses to Members of the Public from Intake of Radionclides, Pergamon Press, New York, NY, ICRP Pub. 56, Part 1.

International Commission on Radiological Protection (ICRP) (1991a), Annual Limits of Intake of Radionuclides by Workers Based on the 1990 Recommendations, Pergamon Press, New York, NY, ICRP Pub. 61.
International Commission on Radiological Protection (ICRP) (1991b), 1990 Recommendations of the International Commission on Radiological Protection, Pergamon Press, New York, NY, ICRP Pub. 60.

International Commission on Radiological Protection (ICRP) (1993), AgeDependent Dose to Members of the Public from Intake of Radionuclides: Part 2 Ingestion Dose Coefficients, Pergamon Press, New York, NY, ICRP Pub. 67.

International Commission on Radiological Protection (ICRP) (1994), Human Respiratory Tract Model for Radiological Protection, Pergamon Press, New York, ICRP Pub. 66.

Jennings, C. D. and M. E. Mount (1983), The Northern Marshall Islands Radiological Survey: A Quality Control Program for Radiochemical Analysis, Lawrence Livermore National Laboratory, Livermore, CA, UCRL-52853, Pt. 5.

Joint FAO/WHO/UNU Expert Consultatio n (1985), Energy and Protein Requirements, World Health Organization Technical Report Series 724, World Health Organization, Geneva.

Kerr, G. D. (1980), “A Review of Organ Doses from Isotropic Fields of Gamma Rays," Health Physics 39, 3-20.

Leggett, R. W. (1986), "Predicting the Retention of Cesium in Individuals," Health Physics 50, 747-759.

Layton, D. W. (1993), “Metabolically Consistent Breathing Rates for Use in Dose Assessments," Health Physics 64(1), 23-36.

Leggett, R. W., K. F. Eckerman, and L. R. Williams (1982), "Strontium-90 in Bone: A Case Study in Age-Dependent Dosimetric Modeling," Health Physics 43, 307-322.

McCraw, T. F., and O. D. T. Lynch Jr. (1973), Exposure Rate Reduction on Bikini Island due to Concrete Dwellings, Wash-1273, UC-41. 
Miltenberger, R. P., N. A. Greenhouse, and E. T. Lessard (1980a), "Whole Body Counting Results from 1974 to 1979 for Bikini Island Residents," Health Physics 39, 395-407.

Miltenberger, R. P., N. Greenhouse, F. Cua, and E. Lessard (1980b), Working Draft Dietary Radioactivity Intake from Bioassay Data: A Model Applied to Cesium-137 Intake by Bikikni Island Residents, Brookhaven National Laboratory, personal communication.

Miltenberger, R., and E. Lessard (1987), Body Burden and Dose Assessment for Bikini Island Residents 1969-1980, Brookhaven National Laboratory, Upton, NY, private communication.

Miltenberger, R., E. Lessard, and N. A. Greenhouse (1981), "Cobalt-60 and Cesium-137 Long Term Biological Removal Rate Constants for the Marshallese Population," Health Physics 40(5), 615-623.

Murai, M. (1954), "Nutrition Study in Micronesia," Atoll Research Bulletin 27, 1-239.

Murai, M., F. Pen, and C. Miller (1958), Some Tropical South Pacific Island Food: Description, History, Use, Composition and Nutritive Value, University of Hawaii Press, Honolulu, HI.

Naidu, J., N. A. Greenhouse, G. Knight, and E. C. Craighead (1980), Marshall Islands: A Study of Diet and Living Patterns, Brookhaven National Laboratory, Upton, NY, Report BNL-51313.

National Academy of Science (NAS) (1980), "Food and Nutrition Board," Recommended Dietary Allowances, Washington, DC, 9th revised edition.

National Council on Radiation Protection and Measurements (NCRP) (1977), Cesium-137 from the Environment to Man: Metabolism and Dose, National Council on Radiation Protection and Measurements, Washington, DC, NCRP-52.
National Council on Radiation Protection and Measurements (NCRP) (1993), Limitation of Exposure to Ionizing Radiation, National Council on Radiation Protection and Measurements, Washington, DC, NCRP-116.

National Research Council (NRC) (1990), Health Effects of Exposure to Low Levels Of Ionizing Radiation (BEIR V). National Academy Press, Washington, DC.

National Research Council (NRC) (1994), Science and Judgment in Risk Assessment, National Academy Press, Washington, DC.

Noshkin, V. E., R. J. Eagle, K. M. Wong, T. A. Jokela, J. L. Brunk, and K. V. Marsh (1981a), Concentrations of Radionuclides in Reef and Lagoon Pelagic Fish from the Marshall islands, Lawrence Livermore National Laboratory, Livermore, CA, UCID19028.

Noshkin, V. E., R. J. Eagle, K. M. Wong, T. A. Jokela, W. L. Robison (1981b), Radionuclide Concentrations and Dose Assessment of Cistern Water and Groundwater at the Marshall Islands, Lawrence Livermore National Laboratory, Livermore, CA, UCRL52853, Pt. 2.

Noshkin, V. E., K. M. Wong, R. J. Eagle, and W. L. Robison (1987), “Comparative Concentrations of ${ }^{137} \mathrm{Cs},{ }^{90} \mathrm{Sr},{ }^{239,240} \mathrm{Pu}$, and ${ }^{241} \mathrm{Am}$ in Tissues of Fish from the Marshall Islands and Calculated Dose Commitments from their Consumption," In Environmental Research on Actinide Elements, proceedings of a symposium, Hilton Head, SC, November 7-11, 1983, pp. 391-.

Noshkin, V. E., W. L. Robison, and K. M. Wong (1994), "Concentration of ${ }^{210} \mathrm{Po}$ and ${ }^{210} \mathrm{~Pb}$ in the Diet at the Marshall Islands," The Science of the Total Environment, 155, 87-104.

Nuclear Regulatory Commission (NRC) (1997), Federal Register, 10 CFR 20.1400, Vol. 62 No. 139, Annex E. 
O'Brien, K. (1980), Human Dose from Radiation of Terrestrial Origin, CONF780422

Pennington, J. A. T. (1976), Dietary Nutrient Guide (Avi Publishing Co., Westport, $\mathrm{CO})$.

Robison, W. L., W. A. Phillips, M. E. Mount, B. R. Clegg, and C. L. Conrado (1980), Reassessment of the Potential Radiological Doses for Residents Resettling Enewetak Atoll, Lawrence Livermore National Laboratory, Livermore, CA, UCRL-53066.

Robison, W. L., C. L. Conrado, R. J. Eagle, and M. L. Stuart (1981a), The Northern Marshall Islands Radiological Surveys: Sampling and Analysis Summary, Lawrence Livermore National Laboratory, Livermore, CA, UCRL52853, Pt. 1

Robison, W. L., V. E. Noshkin, W. A. Phillips, and R. J. Eagle (1981b), The Northern Marshall Islands Radiological Surveys: Radionuclide Concentrations in Fish and Clams and Estimated Doses via the Marine Pathway, Lawrence Livermore National Laboratory, Livermore, CA, UCRL-52853, Pt. 3.

Robison, W. L., M. E. Mount, W. A. Phillips, C. A. Conrado, M. L. Stuart, and A C. Stoker (1982), The Northern Marshall Islands Radiological Survey: Terrestrial Food Chain and Total Doses, Lawrence Livermore National Laboratory, Livermore, CA, UCRL-52853, Part 4.

Robison, W. L., and W. A. Phillips (1989), Estimates of the Radiological Dose from Ingestion of ${ }^{137} \mathrm{Cs}$ and ${ }^{90} \mathrm{Sr}$ to Infants, Children, and Adults in the Marshall Islands, Lawrence Livermore National Laboratory, Livermore, CA, UCRL53917.

Robison, W. L. (1993), Unpublished data.

Robison, W. L., C. L. Conrado, and K. T. Bogen (1994), An Updated Dose Assessment for Rongelap Island, Lawrence Livermore National Laboratory, Livermore, CA, UCRL-LR-107036.
Robison, W. L., K. T. Bogen, C. L. Conrado (1997), “An Updated Dose Assessment for Resettlement Options at Bikini Atoll-A U. S. Nuclear Test Site," Health Physics 73(1), 100-114.

Robison, W. L. and C. L. Conrado (1997), Concentration Ratios for Food Grown on Bikini Island at Bikini Atoll, Lawrence Livermore National Laboratory, Livermore, CA, UCRL-JC128784 (Submitted to the International Atomic Energy Agency (IAEA) for the Coordinated Research Program (CRP): Radionuclide Transfer from Air, Soil, and Freshwater to the Food Chain of Man in Tropical and Sub-Tropical Environment).

Robison, W.L. and C. Sun (1997), "The Use of Comparative 137Cs Body Burden Estimates from Environmental Data/Models and Whole Body Counting to Evaluate Diet Models for the Ingestion Pathway," Health Physics 73(1), 152-166.

Rupp, E. M. (1980), “Age Dependent Values of Dietary Intake for Assessing Human Exposures to Environmental Pollutants," Health Physics 39, 151-163.

Shingleton, K. L., J. L. Cate, M. G. Trent, and W. L. Robison (1987), Bikini Atoll Ionizing Radiation Survey May 1985-May 1986, Lawrence Livermore National Laboratory, Livermore, CA, UCRL-53798.

Shinn, J. H., D. N. Homan, and W. L. Robison (1997), "Resuspension Studies in the Marshall Islands," Health Physics 73(1) 248-257.

Sun, C. (1992), Personal Communication, Brookhaven National Laboratory (BNL).

Tipton, W. J., and R. A. Meibaum (1981), An Aerial Radiological and Photographic Survey of Eleven Atolls and Two Islands within the Northern Marshall Islands, EG\&G, Las Vegas, NV, EGG1183-1758.

Watt, B. and A. Merrill (Revised December 1963), Agricultural Handbook No. 8, Composition of Foods-Raw, Processed, Prepared. 
Williams, G., J. Jankowski, W. P. Swanson, and G. Drexler (1985), " Comparison of Experimental and Theoretical Depth Doses in the ICRU Sphere Using ${ }^{137} \mathrm{Cs}$," Health Physics 49(1), 94-98.

Wilson, A. G. (1985), Assistant Attorney General to the Trust Territory of the Pacific Island, in charge of the Enewetak Food Program, personal communication.
Yang, Y., and C. B. Nelson (1986), “An Estimation of Daily Food Usage Factors for Assessing Radionuclide Intakes in the U.S. Population," Health Physics 50, 245-257. 

Appendix A-1

137Cs Concentration in Soil, Utirik Atoll 
Appendix A-1.1. Cesium-137 radionuclide concentration summary for all soil profiles taken during the 1978 NMIRS and in 1993 on Utirik Island (06I), Utirik Atoll.

\begin{tabular}{|c|c|c|c|c|c|c|c|c|c|}
\hline \multirow{2}{*}{$\begin{array}{c}\text { Soil } \\
\text { depth } \\
(\mathrm{cm})\end{array}$} & \multirow[b]{2}{*}{$\mathrm{N}^{\mathrm{a}}$} & \multirow[b]{2}{*}{ MDA's ${ }^{b}$} & \multirow[b]{2}{*}{ b Minimum } & \multicolumn{4}{|c|}{ Bq g $\mathbf{g}^{-1}$ dry wt. } & \multirow{2}{*}{$\begin{array}{l}\text { Mean } \\
\text { of logs }\end{array}$} & \multirow{2}{*}{$\begin{array}{c}\text { SD } \\
\text { of } \log s\end{array}$} \\
\hline & & & & Maximum & Median & Mean & SD & & \\
\hline 00-05 & 182 & 7 & $1.2 \times 10^{-4}$ & $2.9 \times 10^{-1}$ & $5.4 \times 10^{-2}$ & $6.0 \times 10^{-2}$ & $4.8 \times 10^{-2}$ & $-3.3 \times 10^{0}$ & $1.4 \times 10^{0}$ \\
\hline 05-10 & 171 & 1 & $2.1 \times 10^{-4}$ & $1.4 \times 10^{-1}$ & $1.9 \times 10^{-2}$ & $2.6 \times 10^{-2}$ & $2.3 \times 10^{-2}$ & $-4.1 \times 10^{0}$ & $1.1 \times 10^{0}$ \\
\hline $10-15$ & 173 & 2 & $5.2 \times 10^{-4}$ & $8.3 \times 10^{-2}$ & $8.8 \times 10^{-3}$ & $1.3 \times 10^{-2}$ & $1.4 \times 10^{-2}$ & $-4.8 \times 10^{0}$ & $9.5 \times 10^{-1}$ \\
\hline $15-25$ & 172 & 6 & $2.7 \times 10^{-4}$ & $6.7 \times 10^{-2}$ & $4.0 \times 10^{-3}$ & $6.8 \times 10^{-3}$ & $8.8 \times 10^{-3}$ & $-5.5 \times 10^{0}$ & $9.3 \times 10^{-1}$ \\
\hline $25-40$ & 170 & 41 & $2.7 \times 10^{-5}$ & $4.0 \times 10^{-2}$ & $1.5 \times 10^{-3}$ & $2.9 \times 10^{-3}$ & $4.8 \times 10^{-3}$ & $-6.4 \times 10^{0}$ & $1.0 \times 10^{0}$ \\
\hline $40-60$ & 163 & 90 & $9.3 \times 10^{-5}$ & $7.3 \times 10^{-3}$ & $8.9 \times 10^{-4}$ & $1.2 \times 10^{-3}$ & $1.0 \times 10^{-3}$ & $-7.0 \times 10^{0}$ & $7.2 \times 10^{-1}$ \\
\hline 00-05 & 182 & 7 & $1.2 \times 10^{-4}$ & $2.9 \times 10^{-1}$ & $5.4 \times 10^{-2}$ & $6.0 \times 10^{-2}$ & $4.8 \times 10^{-2}$ & $-3.3 \times 10^{0}$ & $1.4 \times 10^{0}$ \\
\hline 00-10 & 171 & 2 & $2.5 \times 10^{-4}$ & $1.9 \times 10^{-1}$ & $3.7 \times 10^{-2}$ & $4.4 \times 10^{-2}$ & $3.2 \times 10^{-2}$ & $-3.4 \times 10^{0}$ & $9.6 \times 10^{-1}$ \\
\hline 00-15 & 169 & 4 & $7.4 \times 10^{-4}$ & $1.4 \times 10^{-1}$ & $2.9 \times 10^{-2}$ & $3.4 \times 10^{-2}$ & $2.4 \times 10^{-2}$ & $-3.7 \times 10^{0}$ & $8.4 \times 10^{-1}$ \\
\hline 00-25 & 166 & 8 & $1.7 \times 10^{-3}$ & $9.2 \times 10^{-2}$ & $1.9 \times 10^{-2}$ & $2.4 \times 10^{-2}$ & $1.6 \times 10^{-2}$ & $-4.0 \times 10^{0}$ & $7.5 \times 10^{-1}$ \\
\hline $00-40$ & 161 & 40 & $1.6 \times 10^{-3}$ & $5.8 \times 10^{-2}$ & $1.3 \times 10^{-2}$ & $1.6 \times 10^{-2}$ & $1.0 \times 10^{-2}$ & $-4.4 \times 10^{0}$ & $6.9 \times 10^{-1}$ \\
\hline $00-60$ & 152 & 95 & $1.1 \times 10^{-3}$ & $3.9 \times 10^{-2}$ & $8.7 \times 10^{-3}$ & $1.1 \times 10^{-2}$ & $6.7 \times 10^{-3}$ & $-4.7 \times 10^{0}$ & $6.1 \times 10^{-1}$ \\
\hline
\end{tabular}

NOTE: Specific Activity is decay corrected to 1998.

a Number of individual samples or when integrated, number of complete profiles.

b Number of samples with minimum detection activities (MDA's) or when integrated, number of profiles that have one or more MDA's. 
Appendix A-1.2. Cesium-137 radionuclide concentration summary for all soil profiles taken in 1993 on Utirik Island (06I), Utirik Atoll.

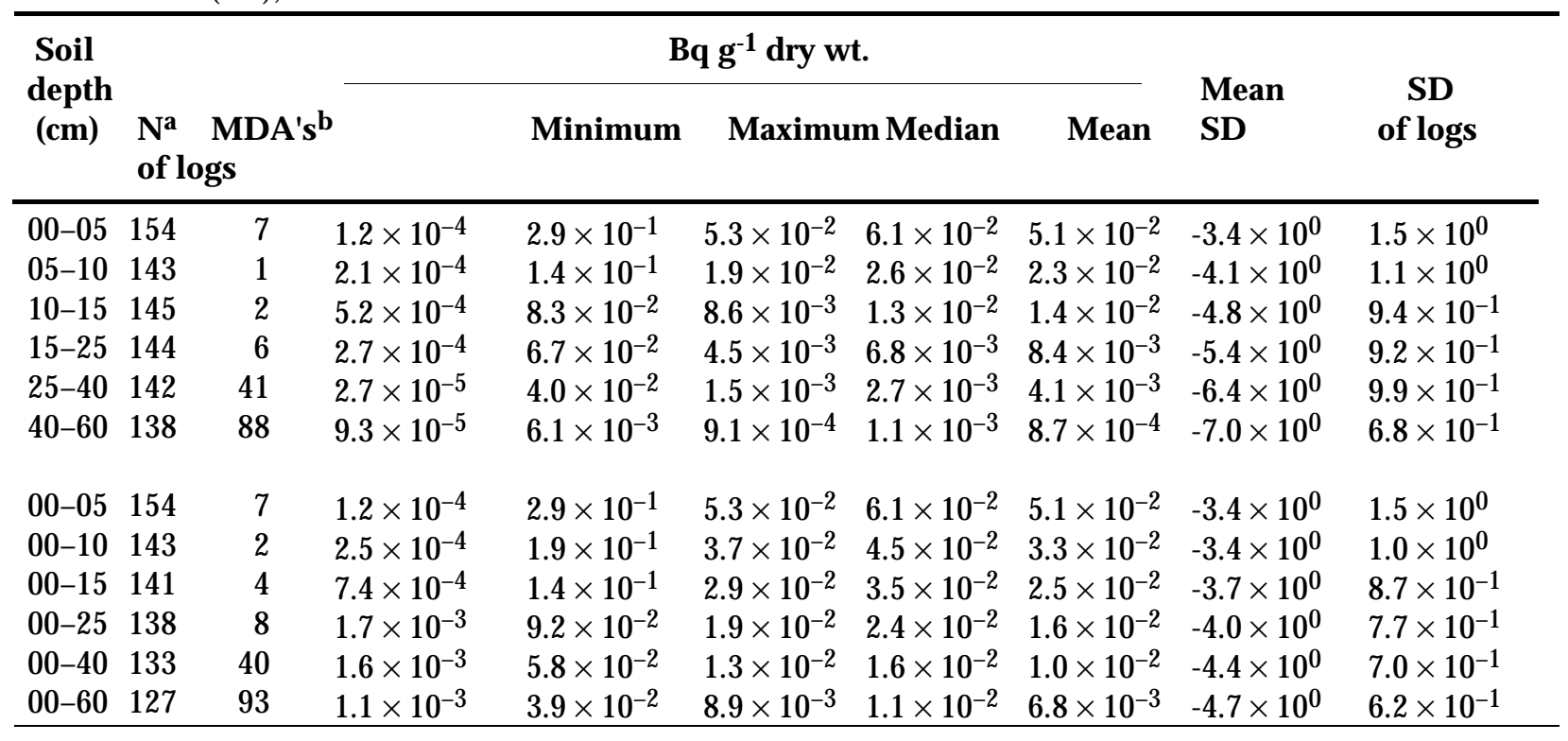

NOTE: Specific Activity is decay corrected to 1998.

a Number of individual samples or when integrated, number of complete profiles.

b Number of samples with minimum detection activities (MDA's) or when integrated, number of profiles that have one or more MDA's. 
Appendix A-1.3. Cesium-137 radionuclide concentration summary for all soil profiles taken during the 1978 NMIRS on Utirik Island (06I), Utirik Atoll.

\begin{tabular}{|c|c|c|c|c|c|c|c|c|c|}
\hline \multirow{2}{*}{$\begin{array}{c}\text { Soil } \\
\text { depth } \\
\text { (cm) }\end{array}$} & \multirow[b]{2}{*}{$\mathbf{N}^{\mathbf{a}}$} & \multirow[b]{2}{*}{ MDA's ${ }^{b}$} & \multicolumn{5}{|c|}{ Bq g $^{-1}$ dry wt. } & \multirow{2}{*}{$\begin{array}{r}\text { Mean } \\
\text { of logs }\end{array}$} & \multirow{2}{*}{$\begin{array}{c}\text { SD } \\
\text { of logs }\end{array}$} \\
\hline & & & $\mathrm{b}$ Minimum & Maximum & Median & Mean & SD & & \\
\hline $00-05$ & 28 & 0 & $5.4 \times 10^{-3}$ & $1.2 \times 10^{-1}$ & $5.7 \times 10^{-2}$ & $5.7 \times 10^{-2}$ & $2.8 \times 10^{-2}$ & $-3.0 \times 10^{0}$ & $7.0 \times 10^{-1}$ \\
\hline $05-10$ & 28 & 0 & $2.0 \times 10^{-3}$ & $8.4 \times 10^{-2}$ & $1.7 \times 10^{-2}$ & $2.6 \times 10^{-2}$ & $2.3 \times 10^{-2}$ & $-4.1 \times 10^{0}$ & $1.1 \times 10^{0}$ \\
\hline $10-15$ & 28 & 0 & $1.6 \times 10^{-3}$ & $7.0 \times 10^{-2}$ & $9.7 \times 10^{-3}$ & $1.5 \times 10^{-2}$ & $1.7 \times 10^{-2}$ & $-4.6 \times 10^{0}$ & $9.7 \times 10^{-1}$ \\
\hline $15-25$ & 28 & 0 & $1.0 \times 10^{-3}$ & $5.4 \times 10^{-2}$ & $3.3 \times 10^{-3}$ & $7.1 \times 10^{-3}$ & $1.1 \times 10^{-2}$ & $-5.5 \times 10^{0}$ & $9.7 \times 10^{-1}$ \\
\hline $25-40$ & 28 & 0 & $3.4 \times 10^{-4}$ & $3.7 \times 10^{-2}$ & $1.4 \times 10^{-3}$ & $3.9 \times 10^{-3}$ & $7.3 \times 10^{-3}$ & $-6.3 \times 10^{0}$ & $1.1 \times 10^{0}$ \\
\hline $40-60$ & 25 & 2 & $1.2 \times 10^{-4}$ & $7.3 \times 10^{-3}$ & $8.1 \times 10^{-4}$ & $1.3 \times 10^{-3}$ & $1.6 \times 10^{-3}$ & $-7.1 \times 10^{0}$ & $9.2 \times 10^{-1}$ \\
\hline 00-05 & 28 & 0 & $5.4 \times 10^{-3}$ & $1.2 \times 10^{-1}$ & $5.7 \times 10^{-2}$ & $5.7 \times 10^{-2}$ & $2.8 \times 10^{-2}$ & $-3.0 \times 10^{0}$ & $7.0 \times 10^{-1}$ \\
\hline 00-10 & 28 & 0 & $3.7 \times 10^{-3}$ & $1.0 \times 10^{-1}$ & $3.9 \times 10^{-2}$ & $4.2 \times 10^{-2}$ & $2.3 \times 10^{-2}$ & $-3.4 \times 10^{0}$ & $7.4 \times 10^{-1}$ \\
\hline 00-15 & 28 & 0 & $3.7 \times 10^{-3}$ & $8.9 \times 10^{-2}$ & $2.9 \times 10^{-2}$ & $3.3 \times 10^{-2}$ & $2.0 \times 10^{-2}$ & $-3.6 \times 10^{0}$ & $7.3 \times 10^{-1}$ \\
\hline $00-25$ & 28 & 0 & $3.8 \times 10^{-3}$ & $6.5 \times 10^{-2}$ & $1.9 \times 10^{-2}$ & $2.3 \times 10^{-2}$ & $1.4 \times 10^{-2}$ & $-4.0 \times 10^{0}$ & $6.6 \times 10^{-1}$ \\
\hline $00-40$ & 28 & 0 & $3.2 \times 10^{-3}$ & $4.8 \times 10^{-2}$ & $1.2 \times 10^{-2}$ & $1.6 \times 10^{-2}$ & $1.1 \times 10^{-2}$ & $-4.4 \times 10^{0}$ & $6.5 \times 10^{-1}$ \\
\hline $00-60$ & 25 & 2 & $3.3 \times 10^{-3}$ & $3.2 \times 10^{-2}$ & $8.3 \times 10^{-3}$ & $1.0 \times 10^{-2}$ & $6.1 \times 10^{-3}$ & $-4.8 \times 10^{0}$ & $5.4 \times 10^{-1}$ \\
\hline
\end{tabular}

NOTE: Specific Activity is decay corrected to 1998.

a Number of individual samples or when integrated, number of complete profiles.

$\mathrm{b}$ Number of samples with minimum detection activities (MDA's) or when integrated, number of profiles that have one or more MDA's. 
Appendix A-1.4. Cesium-137 radionuclide concentration summary for all soil profiles taken in the village area in 1993 on Utirik Island (06I), Utirik Atoll.

\begin{tabular}{|c|c|c|c|c|c|c|c|c|c|}
\hline \multirow{2}{*}{$\begin{array}{l}\text { Soil } \\
\text { depth } \\
\text { (cm) }\end{array}$} & \multirow[b]{2}{*}{$\mathbf{N}^{\mathbf{a}}$} & \multirow[b]{2}{*}{ MDA's $^{b}$} & \multicolumn{5}{|c|}{ Bq g ${ }^{-1}$ dry wt. } & \multirow{2}{*}{$\begin{array}{c}\text { Mean } \\
\text { of logs }\end{array}$} & \multirow{2}{*}{$\begin{array}{l}\text { SD } \\
\text { of logs }\end{array}$} \\
\hline & & & Minimum & Maximum & Median & Mean & SD & & \\
\hline $00-05$ & 17 & 0 & $1.3 \times 10^{-3}$ & $1.3 \times 10^{-1}$ & $2.2 \times 10^{-2}$ & $3.6 \times 10^{-2}$ & $3.6 \times 10^{-2}$ & $-4.0 \times 10^{0}$ & $1.4 \times 10^{0}$ \\
\hline 05-10 & 16 & 0 & $3.7 \times 10^{-3}$ & $1.4 \times 10^{-1}$ & $1.7 \times 10^{-2}$ & $2.6 \times 10^{-2}$ & $3.3 \times 10^{-2}$ & $-4.1 \times 10^{0}$ & $9.7 \times 10^{-1}$ \\
\hline $10-15$ & 16 & 0 & $2.2 \times 10^{-3}$ & $8.3 \times 10^{-2}$ & $8.4 \times 10^{-3}$ & $2.0 \times 10^{-2}$ & $2.5 \times 10^{-2}$ & $-4.6 \times 10^{0}$ & $1.2 \times 10^{0}$ \\
\hline $15-25$ & 17 & 2 & $7.9 \times 10^{-4}$ & $6.7 \times 10^{-2}$ & $3.7 \times 10^{-3}$ & $1.1 \times 10^{-2}$ & $1.7 \times 10^{-2}$ & $-5.4 \times 10^{0}$ & $1.3 \times 10^{0}$ \\
\hline $25-40$ & 16 & 6 & $5.6 \times 10^{-4}$ & $1.5 \times 10^{-2}$ & $1.7 \times 10^{-3}$ & $3.0 \times 10^{-3}$ & $3.7 \times 10^{-3}$ & $-6.3 \times 10^{0}$ & $9.4 \times 10^{-1}$ \\
\hline $40-60$ & 15 & 4 & $4.7 \times 10^{-4}$ & $3.3 \times 10^{-3}$ & $1.1 \times 10^{-3}$ & $1.5 \times 10^{-3}$ & $7.3 \times 10^{-4}$ & $-6.7 \times 10^{0}$ & $4.9 \times 10^{-1}$ \\
\hline 00-05 & 17 & 0 & $1.3 \times 10^{-3}$ & $1.3 \times 10^{-1}$ & $2.2 \times 10^{-2}$ & $3.6 \times 10^{-2}$ & $3.6 \times 10^{-2}$ & $-4.0 \times 10^{0}$ & $1.4 \times 10^{0}$ \\
\hline 00-10 & 16 & 0 & $2.9 \times 10^{-3}$ & $9.2 \times 10^{-2}$ & $2.4 \times 10^{-2}$ & $3.2 \times 10^{-2}$ & $2.7 \times 10^{-2}$ & $-3.8 \times 10^{0}$ & $1.0 \times 10^{0}$ \\
\hline 00-15 & 16 & 0 & $2.7 \times 10^{-3}$ & $7.0 \times 10^{-2}$ & $2.3 \times 10^{-2}$ & $2.8 \times 10^{-2}$ & $2.0 \times 10^{-2}$ & $-3.9 \times 10^{0}$ & $9.8 \times 10^{-1}$ \\
\hline $00-25$ & 16 & 1 & $2.2 \times 10^{-3}$ & $5.2 \times 10^{-2}$ & $1.8 \times 10^{-2}$ & $2.1 \times 10^{-2}$ & $1.5 \times 10^{-2}$ & $-4.2 \times 10^{0}$ & $9.6 \times 10^{-1}$ \\
\hline 00-40 & 15 & 5 & $2.1 \times 10^{-3}$ & $3.8 \times 10^{-2}$ & $1.4 \times 10^{-2}$ & $1.5 \times 10^{-2}$ & $1.0 \times 10^{-2}$ & $-4.4 \times 10^{0}$ & $8.0 \times 10^{-1}$ \\
\hline $00-60$ & 14 & 5 & $2.0 \times 10^{-3}$ & $2.6 \times 10^{-2}$ & $1.0 \times 10^{-2}$ & $1.1 \times 10^{-2}$ & $6.6 \times 10^{-3}$ & $-4.7 \times 10^{0}$ & $6.5 \times 10^{-1}$ \\
\hline
\end{tabular}

NOTE: Specific Activity is decay corrected to 1998.

a Number of individual samples or when integrated, number of complete profiles.

b Number of samples with minimum detection activities (MDA's) or when integrated, number of profiles that have one or more MDA's.

Appendix A-1.5. Cesium-137 radionuclide concentration summary for all soil profiles taken in the interior area in 1993 on Utirik Island (06I), Utirik Atoll.

\begin{tabular}{|c|c|c|c|c|c|c|c|c|c|}
\hline \multirow{2}{*}{$\begin{array}{l}\text { Soil } \\
\text { depth } \\
\text { (cm) }\end{array}$} & \multirow[b]{2}{*}{$\mathbf{N}^{\mathbf{a}}$} & \multirow[b]{2}{*}{ MDA's $^{b}$} & \multicolumn{5}{|c|}{ Bq $g^{-1}$ dry wt. } & \multirow{2}{*}{$\begin{array}{l}\text { Mean } \\
\text { of logs }\end{array}$} & \multirow{2}{*}{$\begin{array}{l}\text { SD } \\
\text { of logs }\end{array}$} \\
\hline & & & Minimum & Maximum & Median & Mean & SD & & \\
\hline 00-05 & 130 & 2 & $2.9 \times 10^{-4}$ & $2.9 \times 10^{-1}$ & $5.9 \times 10^{-2}$ & $6.7 \times 10^{-2}$ & $5.1 \times 10^{-2}$ & $-3.1 \times 10^{0}$ & $1.1 \times 10^{0}$ \\
\hline 05-10 & 127 & 1 & $2.1 \times 10^{-4}$ & $9.9 \times 10^{-2}$ & $1.9 \times 10^{-2}$ & $2.6 \times 10^{-2}$ & $2.2 \times 10^{-2}$ & $-4.1 \times 10^{0}$ & $1.1 \times 10^{0}$ \\
\hline $10-15$ & 129 & 2 & $5.2 \times 10^{-4}$ & $7.7 \times 10^{-2}$ & $8.7 \times 10^{-3}$ & $1.2 \times 10^{-2}$ & $1.2 \times 10^{-2}$ & $-4.8 \times 10^{0}$ & $1 \times 10^{-1}$ \\
\hline $15-25$ & 127 & 4 & $2.7 \times 10^{-4}$ & $5.6 \times 10^{-2}$ & $4.8 \times 10^{-3}$ & $6.2 \times 10^{-3}$ & $6.5 \times 10^{-3}$ & $-5.5 \times 10^{0}$ & $8.7 \times 10^{-1}$ \\
\hline $25-40$ & 126 & 35 & $2.7 \times 10^{-5}$ & $4.0 \times 10^{-2}$ & $1.5 \times 10^{-3}$ & $2.7 \times 10^{-3}$ & $4.2 \times 10^{-3}$ & $-6.4 \times 10^{0}$ & $1.0 \times 10^{0}$ \\
\hline $40-60$ & 123 & 84 & $9.3 \times 10^{-5}$ & $6.1 \times 10^{-3}$ & $8.4 \times 10^{-4}$ & $1.1 \times 10^{-3}$ & $8.8 \times 10^{-4}$ & $-7.1 \times 10^{0}$ & $6.9 \times 10^{-1}$ \\
\hline 00-05 & 130 & 2 & $2.9 \times 10^{-4}$ & $2.9 \times 10^{-1}$ & $5.9 \times 10^{-2}$ & $6.7 \times 10^{-2}$ & $5.1 \times 10^{-2}$ & $-3.1 \times 10^{0}$ & $1.1 \times 10^{0}$ \\
\hline 00-10 & 127 & 2 & $2.5 \times 10^{-4}$ & $1.9 \times 10^{-1}$ & $3.8 \times 10^{-2}$ & $4.6 \times 10^{-2}$ & $3.4 \times 10^{-2}$ & $-3.4 \times 10^{0}$ & $9.9 \times 10^{-1}$ \\
\hline 00-15 & 125 & 4 & $7.4 \times 10^{-4}$ & $1.4 \times 10^{-1}$ & $2.9 \times 10^{-2}$ & $3.5 \times 10^{-2}$ & $2.5 \times 10^{-2}$ & $-3.6 \times 10^{0}$ & $8.5 \times 10^{-1}$ \\
\hline $00-25$ & 122 & 7 & $1.7 \times 10^{-3}$ & $9.2 \times 10^{-2}$ & $1.9 \times 10^{-2}$ & $2.4 \times 10^{-2}$ & $1.7 \times 10^{-2}$ & $-4.0 \times 10^{0}$ & $7.4 \times 10^{-1}$ \\
\hline 00-40 & 118 & 35 & $1.6 \times 10^{-3}$ & $5.8 \times 10^{-2}$ & $1.3 \times 10^{-2}$ & $1.6 \times 10^{-2}$ & $1.0 \times 10^{-2}$ & $-4.4 \times 10^{0}$ & $6.8 \times 10^{-1}$ \\
\hline $00-60$ & 113 & 88 & $1.1 \times 10^{-3}$ & $3.9 \times 10^{-2}$ & $8.8 \times 10^{-3}$ & $1.1 \times 10^{-2}$ & $6.9 \times 10^{-3}$ & $-4.7 \times 10^{0}$ & $6.2 \times 10^{-1}$ \\
\hline
\end{tabular}

NOTE: Specific Activity is decay corrected to 1998.

a Number of individual samples or when integrated, number of complete profiles.

b Number of samples with minimum detection activities (MDA's) or when integrated, number of profiles that have one or more MDA's. 
Appendix A-1.6. Cesium-137 radionuclide concentration summary for all soil profiles taken during the 1978 NMIRS and in 1994 on Bikrak Island (03I), Utirik Atoll.

\begin{tabular}{|c|c|c|c|c|c|c|c|c|c|}
\hline \multirow{2}{*}{$\begin{array}{r}\text { Soil } \\
\text { depth } \\
(\mathrm{cm})\end{array}$} & \multirow[b]{2}{*}{$\mathbf{N}^{\mathbf{a}}$} & \multirow[b]{2}{*}{ MDA's $^{b}$} & \multirow[b]{2}{*}{ Minimum } & \multicolumn{4}{|c|}{ Bq g-1 dry wt. } & \multirow{2}{*}{$\begin{array}{l}\text { Mean } \\
\text { of logs }\end{array}$} & \multirow{2}{*}{$\begin{array}{l}\text { SD } \\
\text { of logs }\end{array}$} \\
\hline & & & & Maximum & Median & Mean & SD & & \\
\hline 00-05 & 27 & 0 & $1.0 \times 10^{-2}$ & $2.2 \times 10^{-1}$ & $6.9 \times 10^{-2}$ & $7.4 \times 10^{-2}$ & $4.5 \times 10^{-2}$ & $-2.8 \times$ & $7.5 \times 10^{-1}$ \\
\hline 05-10 & 27 & 0 & $4.8 \times$ & $1.2 \times 10^{-1}$ & $3.4 \times 10^{-2}$ & $4.0 \times 10^{-2}$ & & & $9.4 \times 10^{-1}$ \\
\hline $10-15$ & 27 & 0 & $4.8 \times$ & $7.7 \times$ & $1.8 \times$ & -2 & $2.2 \times$ & & $10^{-1}$ \\
\hline $15-25$ & 27 & 0 & $8.5 \times$ & $5.5 \times 10^{-2}$ & $5.1 \times 10^{-3}$ & $1.1 \times 10^{-2}$ & $1.2 \times 10^{-2}$ & $-5.0 \times$ & $1.0 \times 10^{-1}$ \\
\hline $25-40$ & 27 & 8 & $1.8 \times 10^{-4}$ & $3.2 \times 10^{-2}$ & $1.0 \times 10^{-3}$ & $3.3 \times 10^{-3}$ & $6.2 \times 10^{-3}$ & $-6.5 \times 10^{0}$ & $1.1 \times 10^{0}$ \\
\hline $40-60$ & 27 & 15 & $2.5 \times 10^{-4}$ & $5.4 \times 10^{-3}$ & $8.2 \times 10^{-4}$ & $1.2 \times 10^{-3}$ & $1.2 \times 10^{-3}$ & $-7.1 \times 10^{0}$ & $7.5 \times 10^{-1}$ \\
\hline 00-05 & 27 & 0 & $1.0 \times 10^{-2}$ & $2.2 \times 10^{-1}$ & $6.9 \times 10^{-2}$ & $7.4 \times 10^{-2}$ & $4.5 \times 10^{-2}$ & $-2.8 \times 10^{0}$ & $7.5 \times 10^{-1}$ \\
\hline 00-10 & 27 & 0 & $7.7 \times 10^{-3}$ & $1.7 \times 10^{-1}$ & $5.3 \times 10^{-2}$ & $5.7 \times 10^{-2}$ & $3.6 \times 10^{-2}$ & $-3.1 \times 10^{0}$ & $7.8 \times 10^{-1}$ \\
\hline 00-15 & 27 & 0 & $7.2 \times 10^{-3}$ & $1.4 \times 10^{-1}$ & $4.4 \times 10^{-2}$ & $4.6 \times 10^{-2}$ & $3.0 \times 10^{-2}$ & $-3.3 \times 10^{0}$ & $7.6 \times 10^{-1}$ \\
\hline $00-25$ & 27 & 0 & $5.8 \times 10^{-3}$ & $8.8 \times 10^{-2}$ & $2.9 \times 10^{-2}$ & $3.2 \times 10^{-2}$ & $2.1 \times 10^{-2}$ & $-3.7 \times 10^{0}$ & $7.1 \times 10^{-1}$ \\
\hline 00-40 & 27 & 8 & $3.8 \times 10$ & $5.5 \times 10^{-2}$ & $1.9 \times 10^{-2}$ & $2.1 \times 10^{-2}$ & $1.5 \times 10^{-2}$ & $-4.1 \times$ & $7.0 \times 10^{-1}$ \\
\hline $00-60$ & 27 & 17 & $2.8 \times 10^{-3}$ & $3.7 \times 10^{-2}$ & $1.3 \times 10^{-2}$ & $1.5 \times 10^{-2}$ & $9.6 \times 10^{-3}$ & $-4.4 \times 10^{0}$ & $6.7 \times 10^{-1}$ \\
\hline
\end{tabular}

NOTE: Specific Activity is decay corrected to 1998.

a Number of individual samples or when integrated, number of complete profiles.

b Number of samples with minimum detection activities (MDA's) or when integrated, number of profiles that have one or more MDA's. 
Appendix A-1.7. Cesium-137 radionuclide concentration summary for all soil profiles taken in 1994 on Bikrak Island (03I), Utirik Atoll.

\begin{tabular}{|c|c|c|c|c|c|c|c|c|c|}
\hline \multirow{2}{*}{$\begin{array}{c}\text { Soil } \\
\text { depth } \\
\text { (cm) }\end{array}$} & \multirow[b]{2}{*}{$\mathbf{N}^{\mathbf{a}}$} & \multirow[b]{2}{*}{ MDA's $^{b}$} & \multicolumn{5}{|c|}{ Bq g ${ }^{-1}$ dry wt. } & \multirow{2}{*}{$\begin{array}{l}\text { Mean } \\
\text { of logs }\end{array}$} & \multirow{2}{*}{$\begin{array}{l}\text { SD } \\
\text { of logs }\end{array}$} \\
\hline & & & Minimum & Maximum & Median & Mean & SD & & \\
\hline 00-05 & 19 & 0 & $1.0 \times 10^{-2}$ & $1.4 \times 10^{-1}$ & $6.2 \times 10^{-2}$ & $6.1 \times 10^{-2}$ & $3.5 \times 10^{-2}$ & $-3.0 \times 10^{0}$ & $7.5 \times 10^{-1}$ \\
\hline $05-10$ & 19 & 0 & $4.8 \times 10^{-3}$ & $8.4 \times 10^{-2}$ & $3.1 \times 10^{-2}$ & $3.3 \times 10^{-2}$ & $2.6 \times 10^{-2}$ & $-3.8 \times 10^{0}$ & $9.4 \times 10^{-1}$ \\
\hline 10-15 & 19 & 0 & $4.8 \times 10^{-3}$ & $7.7 \times 10^{-2}$ & $1.4 \times 10^{-2}$ & $2.2 \times 10^{-2}$ & $2.1 \times 10^{-2}$ & $-4.2 \times 10^{0}$ & $8.5 \times 10^{-1}$ \\
\hline $15-25$ & 19 & 0 & $8.5 \times 10^{-4}$ & $5.5 \times 10^{-2}$ & $5.1 \times 10^{-3}$ & $1.1 \times 10^{-2}$ & $1.3 \times 10^{-2}$ & $-5.0 \times 10^{0}$ & $9.6 \times 10^{-1}$ \\
\hline $25-40$ & 19 & 4 & $1.8 \times 10^{-4}$ & $3.2 \times 10^{-2}$ & $9.6 \times 10^{-4}$ & $4.0 \times 10^{-3}$ & $7.3 \times 10^{-3}$ & $-6.5 \times 10^{0}$ & $1.3 \times 10^{0}$ \\
\hline $40-60$ & 19 & 12 & $2.5 \times 10^{-4}$ & $5.4 \times 10^{-3}$ & $6.9 \times 10^{-4}$ & $1.1 \times 10^{-3}$ & $1.3 \times 10^{-3}$ & $-7.2 \times 10^{0}$ & $7.6 \times 10^{-1}$ \\
\hline 00-05 & 19 & 0 & $1.0 \times 10^{-2}$ & $1.4 \times 10^{-1}$ & $6.2 \times 10^{-2}$ & $6.1 \times 10^{-2}$ & $3.5 \times 10^{-2}$ & $-3.0 \times 10^{0}$ & $7.5 \times 10^{-1}$ \\
\hline $00-10$ & 19 & 0 & $7.7 \times 10^{-3}$ & $1.1 \times 10^{-1}$ & $4.2 \times 10^{-2}$ & $4.7 \times 10^{-2}$ & $2.9 \times 10^{-2}$ & $-3.3 \times 10^{0}$ & $7.9 \times 10^{-1}$ \\
\hline 00-15 & 19 & 0 & $7.2 \times 10^{-3}$ & $9.2 \times 10^{-2}$ & $3.1 \times 10^{-2}$ & $3.9 \times 10^{-2}$ & $2.5 \times 10^{-2}$ & $-3.5 \times 10^{0}$ & $7.6 \times 10^{-1}$ \\
\hline $00-25$ & 19 & 0 & $5.8 \times 10^{-3}$ & $6.8 \times 10^{-2}$ & $2.0 \times 10^{-2}$ & $2.7 \times 10^{-2}$ & $1.9 \times 10^{-2}$ & $-3.8 \times 10^{0}$ & $7.0 \times 10^{-1}$ \\
\hline $00-40$ & 19 & 4 & $3.8 \times 10^{-3}$ & $5.4 \times 10^{-2}$ & $1.3 \times 10^{-2}$ & $1.9 \times 10^{-2}$ & $1.4 \times 10^{-2}$ & $-4.2 \times 10^{0}$ & $7.0 \times 10^{-1}$ \\
\hline $00-60$ & 19 & 12 & $2.8 \times 10^{-3}$ & $3.7 \times 0^{-2}$ & $9.3 \times 10^{-3}$ & $1.3 \times 10^{-2}$ & $9.0 \times 10^{-3}$ & $-4.6 \times 10^{0}$ & $6.7 \times 10^{-1}$ \\
\hline
\end{tabular}

NOTE: Specific Activity is decay corrected to 1998.

a Number of individual samples or when integrated, number of complete profiles.

b Number of samples with minimum detection activities (MDA's) or when integrated, number of profiles that have one or more MDA's. 
Appendix A-1.8. Cesium-137 radionuclide concentration summary for all soil profiles taken during the 1978 NMIRS on Bikrak Island (03I), Utirik Atoll.

\begin{tabular}{|c|c|c|c|c|c|c|c|c|c|}
\hline \multirow{2}{*}{$\begin{array}{l}\text { Soil } \\
\text { depth } \\
\text { (cm) }\end{array}$} & \multirow[b]{2}{*}{$\mathbf{N}^{\mathbf{a}}$} & \multirow[b]{2}{*}{ MDA's $^{b}$} & \multicolumn{5}{|c|}{$\mathrm{Bq}^{-1}$ dry wt. } & \multirow{2}{*}{$\begin{array}{l}\text { Mean } \\
\text { of logs }\end{array}$} & \multirow{2}{*}{$\begin{array}{l}\text { SD } \\
\text { of logs }\end{array}$} \\
\hline & & & Minimum & Maximum & Median & Mean & SD & & \\
\hline 00-05 & 8 & 0 & $2.9 \times 10^{-2}$ & $2.2 \times 10^{-1}$ & $9.6 \times 10^{-2}$ & $1.0 \times 10^{-1}$ & $5.5 \times 10^{-2}$ & $-2.4 \times 10^{0}$ & $5.8 \times 10^{-1}$ \\
\hline 05-10 & 8 & 0 & $1.2 \times 10^{-2}$ & $1.2 \times 10^{-1}$ & $5.0 \times 10^{-2}$ & $5.5 \times 10^{-2}$ & $3.6 \times 10^{-2}$ & $-3.2 \times 10^{0}$ & $8.3 \times 10^{-1}$ \\
\hline $10-15$ & 8 & 0 & $8.7 \times 10^{-3}$ & $7.1 \times 10^{-2}$ & $2.0 \times 10^{-2}$ & $3.1 \times 10^{-2}$ & $2.4 \times 10^{-2}$ & $-3.7 \times 10^{0}$ & $7.7 \times 10^{-1}$ \\
\hline $15-25$ & 8 & 0 & $1.8 \times 10^{-3}$ & $3.6 \times 10^{-2}$ & $7.9 \times 10^{-3}$ & $1.1 \times 10^{-2}$ & $1.2 \times 10^{-2}$ & $-5.0 \times 10^{0}$ & $1.2 \times 10^{0}$ \\
\hline $25-40$ & 8 & 4 & $8.8 \times 10^{-4}$ & $2.4 \times 10^{-3}$ & $1.2 \times 10^{-3}$ & $1.4 \times 10^{-3}$ & $5.8 \times 10^{-4}$ & $-6.6 \times 10^{0}$ & $3.9 \times 10^{-1}$ \\
\hline $40-60$ & 8 & 3 & $2.8 \times 10^{-4}$ & $2.4 \times 10^{-3}$ & $1.5 \times 10^{-3}$ & $1.4 \times 10^{-3}$ & $6.4 \times 10^{-4}$ & $-6.8 \times 10^{0}$ & $6.9 \times 10^{-1}$ \\
\hline 00-05 & 8 & 0 & $2.9 \times 10^{-2}$ & $2.2 \times 10^{-1}$ & $9.6 \times 10^{-2}$ & $1.0 \times 10^{-1}$ & $5.5 \times 10^{-2}$ & $-2.4 \times 10^{0}$ & $5.8 \times 10^{-1}$ \\
\hline 00-10 & 8 & 0 & $2.1 \times 10^{-2}$ & $1.7 \times 10^{-1}$ & $7.1 \times 10^{-2}$ & $7.9 \times 10^{-2}$ & $4.5 \times 10^{-2}$ & $-2.7 \times 10^{0}$ & $6.3 \times 10^{-1}$ \\
\hline 00-15 & 8 & 0 & $1.8 \times 10^{-2}$ & $1.4 \times 10^{-1}$ & $5.4 \times 10^{-2}$ & $6.3 \times 10^{-2}$ & $3.7 \times 10^{-2}$ & $-2.9 \times 10^{0}$ & $6.4 \times 10^{-1}$ \\
\hline 00-25 & 8 & 0 & $1.1 \times 10^{-2}$ & $8.8 \times 10^{-2}$ & $3.4 \times 10^{-2}$ & $4.2 \times 10^{-2}$ & $2.5 \times 10^{-2}$ & $-3.3 \times 10^{0}$ & $6.5 \times 10^{-1}$ \\
\hline $00-40$ & 8 & 4 & $7.3 \times 10^{-3}$ & $5.5 \times 10^{-2}$ & $2.2 \times 10^{-2}$ & $2.7 \times 10^{-2}$ & $1.6 \times 10^{-2}$ & $-3.8 \times 10^{0}$ & $6.4 \times 10^{-1}$ \\
\hline $00-60$ & 8 & 5 & $5.3 \times 10^{-3}$ & $3.7 \times 10^{-2}$ & $1.5 \times 10^{-2}$ & $1.9 \times 10^{-2}$ & $1.0 \times 10^{-2}$ & $-4.1 \times 10^{0}$ & $6.1 \times 10^{-1}$ \\
\hline
\end{tabular}

NOTE: Specific Activity is decay corrected to 1998.

a Number of individual samples or when integrated, number of complete profiles.

b Number of samples with minimum detection activities (MDA's) or when integrated, number of profiles that have one or more MDA's. 
Appendix A-1.9. Cesium-137 radionuclide concentration summary for all soil profiles taken during the 1978 NMIRS and in 1994 on Aon Island (08I), Utirik Atoll.

\begin{tabular}{|c|c|c|c|c|c|c|c|c|c|}
\hline \multirow{2}{*}{$\begin{array}{l}\text { Soil } \\
\text { depth } \\
(\mathrm{cm})\end{array}$} & \multirow[b]{2}{*}{$\mathbf{N}^{\mathbf{a}}$} & \multirow[b]{2}{*}{ MDA's $^{b}$} & \multicolumn{5}{|c|}{ Bq $g^{-1}$ dry wt. } & \multirow{2}{*}{$\begin{array}{l}\text { Mean } \\
\text { of logs }\end{array}$} & \multirow{2}{*}{$\begin{array}{l}\text { SD } \\
\text { of logs }\end{array}$} \\
\hline & & & Minimum & Maximum & Median & Mean & SD & & \\
\hline 00-05 & 44 & 0 & $3.5 \times 10^{-4}$ & $1.7 \times 10^{-1}$ & $5.3 \times 10^{-2}$ & $5.5 \times 10^{-2}$ & $3.9 \times 10^{-2}$ & $-3.3 \times 10^{0}$ & $1.2 \times 10^{0}$ \\
\hline 05-10 & 44 & 1 & $8.7 \times 10^{-4}$ & $7.6 \times 10^{-2}$ & $1.9 \times 10^{-2}$ & $2.4 \times 10^{-2}$ & $1.8 \times 10^{-2}$ & $-4.1 \times 10^{0}$ & $9.5 \times 10^{-1}$ \\
\hline $10-15$ & 44 & 0 & $7.1 \times 10^{-4}$ & $4.2 \times 10^{-2}$ & $1.1 \times 10^{-2}$ & $1.3 \times 10^{-2}$ & $9.2 \times 10^{-3}$ & $-4.7 \times 10^{0}$ & $8.7 \times 10^{-1}$ \\
\hline $15-25$ & 44 & 0 & $2.3 \times 10^{-4}$ & $3.8 \times 10^{-2}$ & $5.0 \times 10^{-3}$ & $6.9 \times 10^{-3}$ & $7.1 \times 10^{-3}$ & $-5.4 \times 10^{0}$ & $9.3 \times 10^{-1}$ \\
\hline $25-40$ & 43 & 5 & $1.2 \times 10^{-4}$ & $2.7 \times 10^{-2}$ & $2.0 \times 10^{-3}$ & $3.4 \times 10^{-3}$ & $4.5 \times 10^{-3}$ & $-6.2 \times 10^{0}$ & $9.8 \times 10^{-1}$ \\
\hline $40-60$ & 35 & 16 & $3.0 \times 10^{-6}$ & $3.3 \times 10^{-2}$ & $7.3 \times 10^{-4}$ & $2.1 \times 10^{-3}$ & $5.5 \times 10^{-3}$ & $-7.2 \times 10^{0}$ & $1.5 \times 10^{0}$ \\
\hline 00-05 & 44 & 0 & $3.5 \times 10^{-4}$ & $1.7 \times 10^{-1}$ & $5.3 \times 10^{-2}$ & $5.5 \times 10^{-2}$ & $3.9 \times 10^{-2}$ & $-3.3 \times 10^{0}$ & $1.2 \times 10^{0}$ \\
\hline 00-10 & 44 & 1 & $6.1 \times 10^{-4}$ & $1.0 \times 10^{-1}$ & $3.8 \times 10^{-2}$ & $4.0 \times 10^{-2}$ & $2.6 \times 10^{-2}$ & $-3.6 \times 10^{0}$ & $1.0 \times 10^{0}$ \\
\hline 00-15 & 44 & 1 & $6.4 \times 10^{-4}$ & $7.4 \times 10^{-2}$ & $3.0 \times 10^{-2}$ & $3.1 \times 10^{-2}$ & $1.9 \times 10^{-2}$ & $-3.8 \times 10^{0}$ & $9.4 \times 10^{-1}$ \\
\hline 00-25 & 44 & 1 & $8.6 \times 10^{-4}$ & $4.9 \times 10^{-2}$ & $2.0 \times 10^{-2}$ & $2.1 \times 10^{-2}$ & $1.3 \times 10^{-2}$ & $-4.1 \times 10^{0}$ & $8.3 \times 10^{-1}$ \\
\hline $00-40$ & 43 & 5 & $8.9 \times 10^{-4}$ & $3.2 \times 10^{-2}$ & $1.4 \times 10^{-2}$ & $1.5 \times 10^{-2}$ & $8.4 \times 10^{-3}$ & $-4.5 \times 10^{0}$ & $7.6 \times 10^{-1}$ \\
\hline $00-60$ & 34 & 18 & $8.9 \times 10^{-4}$ & $2.8 \times 10^{-2}$ & $1.0 \times 10^{-3}$ & $1.1 \times 10^{-2}$ & $6.5 \times 10^{-3}$ & $-4.8 \times 10^{0}$ & $7.5 \times 10^{-1}$ \\
\hline
\end{tabular}

NOTE: Specific Activity is decay corrected to 1998.

a Number of individual samples or when integrated, number of complete profiles.

b Number of samples with minimum detection activities (MDA's) or when integrated, number of profiles that have one or more MDA's. 
Appendix A-1.10. Cesium-137 radionuclide concentration summary for all soil profiles taken in 1994 on Aon Island (08I), Utirik Atoll.

\begin{tabular}{|c|c|c|c|c|c|c|c|c|c|}
\hline \multirow{2}{*}{$\begin{array}{l}\text { Soil } \\
\text { depth } \\
\text { (cm) }\end{array}$} & \multirow[b]{2}{*}{$\mathbf{N}^{\mathbf{a}}$} & \multirow[b]{2}{*}{ MDA's $^{b}$} & \multicolumn{5}{|c|}{ Bq g-1 dry wt. } & \multirow{2}{*}{$\begin{array}{r}\text { Mean } \\
\text { of } \log s\end{array}$} & \multirow{2}{*}{$\begin{array}{l}\text { SD } \\
\text { of logs }\end{array}$} \\
\hline & & & Minimum & Maximum & Median & Mean & SD & & \\
\hline 00-05 & 34 & 0 & $3.5 \times 10^{-4}$ & $1.7 \times 10^{-1}$ & $5.3 \times 10^{-2}$ & $5.4 \times 10^{-2}$ & $4.0 \times 10^{-2}$ & $-3.4 \times 10^{0}$ & $1.3 \times 10^{0}$ \\
\hline 05-10 & 34 & 1 & $8.7 \times 10^{-4}$ & $7.4 \times 10^{-2}$ & $1.9 \times 10^{-2}$ & $2.2 \times 10^{-2}$ & $1.6 \times 10^{-2}$ & $-4.2 \times 10^{0}$ & $9.6 \times 10^{-1}$ \\
\hline 10-15 & 34 & 0 & $7.1 \times 10^{-4}$ & $4.2 \times 10^{-2}$ & $1.0 \times 10^{-2}$ & $1.3 \times 10^{-2}$ & $9.7 \times 10^{-3}$ & $-4.7 \times 10^{0}$ & $8.8 \times 10^{-1}$ \\
\hline $15-25$ & 34 & 0 & $1.2 \times 10^{-3}$ & $3.8 \times 10^{-2}$ & $5.2 \times 10^{-3}$ & $7.3 \times 10^{-3}$ & $7.9 \times 10^{-3}$ & $-5.3 \times 10^{0}$ & $8.9 \times 10^{-1}$ \\
\hline $25-40$ & 33 & 4 & $1.2 \times 10^{-4}$ & $2.7 \times 10^{-2}$ & $2.0 \times 10^{-3}$ & $3.8 \times 10^{-3}$ & $5.0 \times 10^{-3}$ & $-6.1 \times 10^{0}$ & $1.1 \times 10^{0}$ \\
\hline $40-60$ & 27 & 13 & $3.0 \times 10^{-6}$ & $3.3 \times 10^{-2}$ & $8.1 \times 10^{-4}$ & $2.2 \times 10^{-3}$ & $6.2 \times 10^{-3}$ & $-7.3 \times 10^{0}$ & $1.6 \times 10^{0}$ \\
\hline 00-05 & 34 & 0 & $3.5 \times 10^{-4}$ & $1.7 \times 10^{-1}$ & $5.3 \times 10^{-2}$ & $5.4 \times 10^{-2}$ & $4.0 \times 10^{-2}$ & $-3.4 \times 10^{0}$ & $1.3 \times 10^{0}$ \\
\hline 00-10 & 34 & 1 & $6.1 \times 10^{-4}$ & $9.8 \times 10^{-2}$ & $3.6 \times 10^{-2}$ & $3.8 \times 10^{-2}$ & $2.6 \times 10^{-2}$ & $-3.7 \times 10^{0}$ & $1.1 \times 10^{0}$ \\
\hline 00-15 & 34 & 1 & $6.4 \times 10^{-4}$ & $7.4 \times 10^{-2}$ & $2.7 \times 10^{-2}$ & $2.9 \times 10^{-2}$ & $1.9 \times 10^{-2}$ & $-3.9 \times 10^{0}$ & $9.8 \times 10^{-1}$ \\
\hline 00-25 & 34 & 1 & $8.6 \times 10^{-4}$ & $4.8 \times 10^{-2}$ & $2.0 \times 10^{-2}$ & $2.1 \times 10^{-2}$ & $1.3 \times 10^{-2}$ & $-4.2 \times 10^{0}$ & $8.6 \times 10^{-1}$ \\
\hline $00-40$ & 33 & 4 & $8.9 \times 10^{-4}$ & $3.2 \times 10^{-2}$ & $1.4 \times 10^{-2}$ & $1.4 \times 10^{-2}$ & $8.5 \times 10^{-3}$ & $-4.5 \times 10^{0}$ & $7.9 \times 10^{-1}$ \\
\hline $00-60$ & 26 & 15 & $8.9 \times 10^{-4}$ & $2.8 \times 10^{-2}$ & $1.0 \times 10^{-2}$ & $1.1 \times 10^{-2}$ & $6.8 \times 10^{-3}$ & $-4.8 \times 10^{0}$ & $7.9 \times 10^{-1}$ \\
\hline
\end{tabular}

NOTE: Specific Activity is decay corrected to 1998.

a Number of individual samples or when integrated, number of complete profiles.

b Number of samples with minimum detection activities (MDA's) or when integrated, number of profiles that have one or more MDA's. 
Appendix A-1.11. Cesium-137 radionuclide concentration summary for all soil profiles taken during the 1978 NMIRS on Aon Island (08I), Utirik Atoll.

\begin{tabular}{|c|c|c|c|c|c|c|c|c|c|}
\hline \multirow{2}{*}{$\begin{array}{l}\text { Soil } \\
\text { depth } \\
\text { (cm) }\end{array}$} & \multirow[b]{2}{*}{$\mathrm{N}^{\mathrm{a}}$} & \multirow[b]{2}{*}{ MDA's $^{b}$} & \multicolumn{5}{|c|}{ Bq g-1 dry wt. } & \multirow{2}{*}{$\begin{array}{l}\text { Mean } \\
\text { of logs }\end{array}$} & \multirow{2}{*}{$\begin{array}{l}\text { SD } \\
\text { of logs }\end{array}$} \\
\hline & & & Minimum & Maximum & Median & Mean & SD & & \\
\hline 00-05 & 10 & 0 & $8.1 \times 10^{-3}$ & $1.3 \times 10^{-1}$ & $6.5 \times 10^{-2}$ & $6.2 \times 10^{-2}$ & $3.6 \times 10^{-2}$ & $-3.0 \times 10^{0}$ & $8.3 \times 10^{-1}$ \\
\hline 05-10 & 10 & 0 & $5.0 \times 10^{-3}$ & $7.6 \times 10^{-2}$ & $2.5 \times 10^{-2}$ & $3.0 \times 10^{-2}$ & $2.3 \times 10^{-2}$ & $-3.8 \times 10^{0}$ & $9.0 \times 10^{-1}$ \\
\hline 10-15 & 10 & 0 & $1.3 \times 10^{-3}$ & $2.9 \times 10^{-2}$ & $1.5 \times 10^{-2}$ & $1.4 \times 10^{-2}$ & $7.7 \times 10^{-3}$ & $-4.5 \times 10^{0}$ & $8.9 \times 10^{-1}$ \\
\hline $15-25$ & 10 & 0 & $2.3 \times 10^{-4}$ & $1.2 \times 10^{-2}$ & $4.3 \times 10^{-3}$ & $5.4 \times 10^{-3}$ & $3.6 \times 10^{-3}$ & $-5.6 \times 10^{0}$ & $1.1 \times 10^{0}$ \\
\hline $25-40$ & 10 & 1 & $1.0 \times 10^{-3}$ & $4.2 \times 10^{-3}$ & $1.8 \times 10^{-3}$ & $2.1 \times 10^{-3}$ & $9.7 \times 10^{-4}$ & $-6.3 \times 10^{0}$ & $4.5 \times 10^{-1}$ \\
\hline $40-60$ & 8 & 3 & $2.9 \times 10^{-4}$ & $6.0 \times 10^{-3}$ & $5.6 \times 10^{-4}$ & $1.7 \times 10^{-3}$ & $2.2 \times 10^{-3}$ & $-7.0 \times 10^{0}$ & $1.2 \times 10^{0}$ \\
\hline 00-05 & 10 & 0 & $8.1 \times 10^{-3}$ & $1.3 \times 10^{-1}$ & $6.5 \times 10^{-2}$ & $6.2 \times 10^{-2}$ & $3.6 \times 10^{-2}$ & $-3.0 \times 10^{0}$ & $8.3 \times 10^{-1}$ \\
\hline 00-10 & 10 & 0 & $6.5 \times 10^{-3}$ & $1.0 \times 10^{-1}$ & $4.5 \times 10^{-2}$ & $4.6 \times 10^{-2}$ & $2.8 \times 10^{-2}$ & $-3.3 \times 10^{0}$ & $8.0 \times 10^{-1}$ \\
\hline 00-15 & 10 & 0 & $4.8 \times 10^{-3}$ & $7.4 \times 10^{-2}$ & $3.4 \times 10^{-2}$ & $3.5 \times 10^{-2}$ & $2.0 \times 10^{-2}$ & $-3.6 \times 10^{0}$ & $7.9 \times 10^{-1}$ \\
\hline 00-25 & 10 & 0 & $4.0 \times 10^{-3}$ & $4.9 \times 10^{-2}$ & $2.3 \times 10^{-2}$ & $2.3 \times 10^{-2}$ & $1.3 \times 10^{-2}$ & $-4.0 \times 10^{0}$ & $7.4 \times 10^{-1}$ \\
\hline $00-40$ & 10 & 1 & $3.6 \times 10^{-3}$ & $3.1 \times 10^{-2}$ & $1.5 \times 10^{-2}$ & $1.5 \times 10^{-2}$ & $8.4 \times 10^{-3}$ & $-4.3 \times 10^{0}$ & $6.6 \times 10^{-1}$ \\
\hline $00-60$ & 8 & 3 & $2.6 \times 10^{-3}$ & $2.1 \times 10^{-2}$ & $9.3 \times 10^{-3}$ & $1.0 \times 10^{-2}$ & $5.9 \times 10^{-3}$ & $-4.8 \times 10^{0}$ & $6.6 \times 10^{-1}$ \\
\hline
\end{tabular}

NOTE: Specific Activity is decay corrected to 1998.

a Number of individual samples or when integrated, number of complete profiles.

b Number of samples with minimum detection activities (MDA's) or when integrated, number of profiles that have one or more MDA's. 
Appendix A-1.12. Cesium-137 radionuclide concentration summary for all soil profiles taken in 1994 on Elluk Island (02I), Utirik Atoll.

\begin{tabular}{cccccccccc}
\hline \multirow{2}{*}{$\begin{array}{c}\text { Soil } \\
\text { Depth } \\
\text { (cm) }\end{array}$} & & & \multicolumn{9}{c}{ Bq g-1 dry wt. } \\
\cline { 4 - 8 } $\mathbf{N}^{\mathbf{a}}$ & MDA's $^{\mathbf{b}}$ & Minimum & Maximum & Median & Mean & SD & $\begin{array}{c}\text { Mean } \\
\text { of logs }\end{array}$ & $\begin{array}{c}\text { SD } \\
\text { of logs }\end{array}$ \\
\hline $00-05$ & 2 & 0 & $1.3 \times 10^{-1}$ & $1.8 \times 10^{-1}$ & $1.6 \times 10^{-1}$ & $1.6 \times 10^{-1}$ & $4.1 \times 10^{-2}$ & $-1.9 \times 10^{0}$ & $2.6 \times 10^{-1}$ \\
$05-10$ & 2 & 0 & $2.7 \times 10^{-2}$ & $1.4 \times 10^{-1}$ & $8.1 \times 10^{-2}$ & $8.1 \times 10^{-2}$ & $7.7 \times 10^{-2}$ & $-2.8 \times 10^{0}$ & $1.1 \times 10^{0}$ \\
$10-15$ & 2 & 0 & $7.3 \times 10^{-3}$ & $5.7 \times 10^{-2}$ & $3.2 \times 10^{-2}$ & $3.2 \times 10^{-2}$ & $3.5 \times 10^{-2}$ & $-3.9 \times 10^{0}$ & $1.5 \times 10^{0}$ \\
$15-25$ & 2 & 0 & $1.2 \times 10^{-3}$ & $8.0 \times 10^{-3}$ & $4.6 \times 10^{-3}$ & $4.6 \times 10^{-3}$ & $4.8 \times 10^{-3}$ & $-5.8 \times 10^{0}$ & $1.3 \times 10^{0}$ \\
$25-40$ & 2 & 2 & $2.7 \times 10^{-4}$ & $8.1 \times 10^{-4}$ & $5.4 \times 10^{-4}$ & $5.4 \times 10^{-4}$ & $3.8 \times 10^{-4}$ & $-7.7 \times 10^{0}$ & $7.7 \times 10^{-1}$ \\
$40-60$ & 0 & 0 & $0.0 \times 10^{0}$ & $0.0 \times 10^{0}$ & $0.0 \times 10^{0}$ & $0.0 \times 10^{0}$ & $0.0 \times 10^{0}$ & $-0.0 \times 10^{0}$ & $0.0 \times 10^{0}$ \\
& & & & & & & & & \\
& & & & & & & & \\
$00-05$ & 2 & 0 & $1.3 \times 10^{-1}$ & $1.8 \times 10^{-1}$ & $1.6 \times 10^{-1}$ & $1.6 \times 10^{-1}$ & $4.1 \times 10^{-2}$ & $-1.9 \times 10^{0}$ & $2.6 \times 10^{-1}$ \\
$00-10$ & 2 & 0 & $7.7 \times 10^{-2}$ & $1.6 \times 10^{-1}$ & $1.2 \times 10^{-1}$ & $1.2 \times 10^{-1}$ & $5.9 \times 10^{-2}$ & $-2.2 \times 10^{0}$ & $5.2 \times 10^{-1}$ \\
$00-15$ & 2 & 0 & $5.4 \times 10^{-2}$ & $1.3 \times 10^{-1}$ & $9.0 \times 10^{-2}$ & $9.0 \times 10^{-2}$ & $5.1 \times 10^{-2}$ & $-2.5 \times 10^{0}$ & $6.0 \times 10^{-1}$ \\
$00-25$ & 2 & 0 & $3.3 \times 10^{-2}$ & $7.9 \times 10^{-2}$ & $5.6 \times 10^{-2}$ & $5.6 \times 10^{-2}$ & $3.2 \times 10^{-2}$ & $-3.0 \times 10^{0}$ & $6.2 \times 10^{-1}$ \\
$00-40$ & 2 & 2 & $2.1 \times 10^{-2}$ & $4.9 \times 10^{-2}$ & $3.5 \times 10^{-2}$ & $3.5 \times 10^{-2}$ & $2.0 \times 10^{-2}$ & $-3.4 \times 10^{0}$ & $6.1 \times 10^{-1}$ \\
$00-60$ & 0 & 0 & $0.0 \times 10^{0}$ & $0.0 \times 10^{0}$ & $0.0 \times 10^{0}$ & $0.0 \times 10^{0}$ & $0.0 \times 10^{0}$ & $-0.0 \times 10^{0}$ & $0.0 \times 10^{0}$ \\
\hline
\end{tabular}

NOTE: Specific Activity is decay corrected to 1998.

a Number of individual samples or when integrated, number of complete profiles.

b Number of samples with minimum detection activities (MDA's) or when integrated, number of profiles that have one or more MDA's. 


\section{Appendix A-2}

90Sr Concentration in Soil, Utirik Atoll 
Appendix A-2.1. Srontium-90 radionuclide concentration summary for all soil profiles taken during the 1978 NMIRS on Utirik Island (06I), Utirik Atoll.

\begin{tabular}{|c|c|c|c|c|c|c|c|c|}
\hline \multirow{2}{*}{$\begin{array}{c}\text { Soil } \\
\text { depth } \\
\text { (cm) }\end{array}$} & \multirow[b]{2}{*}{$\mathrm{N}^{\mathrm{a}}$} & \multicolumn{5}{|c|}{$\mathrm{Bq}^{-1}$ dry wt. } & \multirow{2}{*}{$\begin{array}{l}\text { Mean } \\
\text { of logs }\end{array}$} & \multirow{2}{*}{$\begin{array}{l}\text { SD } \\
\text { of logs }\end{array}$} \\
\hline & & Minimum & Maximum & Median & Mean & SD & & \\
\hline $00-05$ & 18 & $7.5 \times 10^{-3}$ & $7.9 \times 10^{-2}$ & $2.9 \times 10^{-2}$ & $3.2 \times 10^{-2}$ & $1.8 \times 10^{-2}$ & $-3.6 \times 10^{0}$ & $6.0 \times 10^{-1}$ \\
\hline 05-10 & 18 & $4.7 \times 10^{-3}$ & $1.0 \times 10^{-1}$ & $2.3 \times 10^{-2}$ & $2.5 \times 10^{-2}$ & $2.4 \times 10^{-2}$ & $-4.1 \times 10^{0}$ & $9.0 \times 10^{-1}$ \\
\hline $10-15$ & 18 & $2.9 \times 10^{-3}$ & $4.4 \times 10^{-2}$ & $1.7 \times 10^{-2}$ & $1.9 \times 10^{-2}$ & $1.3 \times 10^{-2}$ & $-4.2 \times 10^{0}$ & $8.2 \times 10^{-1}$ \\
\hline $15-25$ & 18 & $1.9 \times 10^{-3}$ & $1.9 \times 10^{-2}$ & $7.2 \times 10^{-3}$ & $8.5 \times 10^{-3}$ & $5.2 \times 10^{-3}$ & $-5.0 \times 10^{0}$ & $6.7 \times 10^{-1}$ \\
\hline $25-40$ & 17 & $1.4 \times 10^{-4}$ & $3.3 \times 10^{-2}$ & $4.1 \times 10^{-3}$ & $5.6 \times 10^{-3}$ & $7.6 \times 10^{-3}$ & $-5.8 \times 10^{0}$ & $1.2 \times 10^{0}$ \\
\hline $40-60$ & 15 & $7.5 \times 10^{-5}$ & $5.4 \times 10^{-3}$ & $1.2 \times 10^{-3}$ & $2.2 \times 10^{-3}$ & $1.9 \times 10^{-3}$ & $-6.6 \times 10^{0}$ & $1.2 \times 10^{0}$ \\
\hline $00-5$ & 18 & $7.5 \times 10^{-3}$ & $7.9 \times 10^{-2}$ & $2.9 \times 10^{-2}$ & $3.2 \times 10^{-2}$ & $1.8 \times 10^{-2}$ & $-3.6 \times 10^{0}$ & $6.0 \times 10^{-1}$ \\
\hline $00-10$ & 18 & $6.6 \times 10^{-3}$ & $7.3 \times 10^{-2}$ & $2.4 \times 10^{-2}$ & $2.9 \times 10^{-2}$ & $1.8 \times 10^{-2}$ & $-3.7 \times 10^{0}$ & $6.4 \times 10^{-1}$ \\
\hline 00-15 & 18 & $8.0 \times 10^{-3}$ & $6.2 \times 10^{-2}$ & $2.3 \times 10^{-2}$ & $2.6 \times 10^{-2}$ & $1.6 \times 10^{-2}$ & $-3.9 \times 10^{0}$ & $6.4 \times 10^{-1}$ \\
\hline $00-25$ & 18 & $5.7 \times 10^{-3}$ & $4.5 \times 10^{-2}$ & $1.6 \times 10^{-2}$ & $1.9 \times 10^{-2}$ & $1.1 \times 10^{-2}$ & $-4.2 \times 10^{0}$ & $6.2 \times 10^{-1}$ \\
\hline $00-40$ & 17 & $4.4 \times 10^{-3}$ & $3.0 \times 10^{-2}$ & $1.2 \times 10^{-2}$ & $1.4 \times 10^{-2}$ & $8.1 \times 10^{-3}$ & $-4.4 \times 10^{0}$ & $5.8 \times 10^{-1}$ \\
\hline $00-60$ & 15 & $3.7 \times 10^{-3}$ & $2.0 \times 10^{-2}$ & $7.3 \times 10^{-3}$ & $9.1 \times 10^{-3}$ & $4.5 \times 10^{-3}$ & $-4.8 \times 10^{0}$ & $4.6 \times 10^{-1}$ \\
\hline
\end{tabular}

a Stands for the number of individual samples or when integrated, number of complete profiles.

NOTE: Specific Activity is decay corrected to 1998. 
Appendix A-3

$239+240 \mathrm{Pu}$ Concentration in Soil, Utirik Atoll 
Appendix A-3.1. Plutonium 239+240 radionuclide concentration summary for all soil profiles taken during the 1978 NMIRS on Utirik Island (06I), Utirik Atoll.

\begin{tabular}{|c|c|c|c|c|c|c|c|c|}
\hline \multirow{2}{*}{$\begin{array}{l}\text { Soil } \\
\text { depth } \\
\text { (cm) }\end{array}$} & \multirow[b]{2}{*}{$\mathbf{N}^{\mathbf{a}}$} & \multicolumn{5}{|c|}{ Bq g ${ }^{-1}$ dry wt. } & \multirow{2}{*}{$\begin{array}{l}\text { Mean } \\
\text { of logs }\end{array}$} & \multirow{2}{*}{$\begin{array}{c}\text { SD } \\
\text { of logs }\end{array}$} \\
\hline & & Minimum & Maximum & Median & Mean & SD & & \\
\hline 00-05 & 28 & $2.7 \times 10^{-4}$ & $4.4 \times 10^{-2}$ & $1.5 \times 10^{-2}$ & $1.7 \times 10^{-2}$ & $1.1 \times 10^{-2}$ & $-4.4 \times 10^{0}$ & $9.9 \times 10^{-1}$ \\
\hline 05-10 & 28 & $4.7 \times 10^{-5}$ & $6.7 \times 10^{-2}$ & $6.0 \times 10^{-3}$ & $8.8 \times 10^{-3}$ & $1.3 \times 10^{-2}$ & $-5.5 \times 10^{0}$ & $1.4 \times 10^{0}$ \\
\hline $10-15$ & 25 & $2.3 \times 10^{-4}$ & $1.7 \times 10^{-2}$ & $1.7 \times 10^{-3}$ & $3.2 \times 10^{-3}$ & $3.8 \times 10^{-3}$ & $-6.4 \times 10^{0}$ & $1.2 \times 10^{0}$ \\
\hline $15-25$ & 25 & $8.9 \times 10^{-5}$ & $7.1 \times 10^{-3}$ & $3.4 \times 10^{-4}$ & $8.8 \times 10^{-4}$ & $1.5 \times 10^{-3}$ & $-7.7 \times 10^{0}$ & $1.1 \times 10^{0}$ \\
\hline $25-40$ & 24 & $8.0 \times 10^{-6}$ & $5.7 \times 10^{-3}$ & $1.1 \times 10^{-4}$ & $5.7 \times 10^{-4}$ & $1.3 \times 10^{-3}$ & $-8.9 \times 10^{0}$ & $1.6 \times 10^{0}$ \\
\hline $40-60$ & 20 & $4.5 \times 10^{-6}$ & $2.4 \times 10^{-4}$ & $6.2 \times 10^{-5}$ & $7.7 \times 10^{-5}$ & $6.6 \times 10^{-5}$ & $-9.9 \times 10^{0}$ & $1.1 \times 10^{0}$ \\
\hline 00-05 & 28 & $2.7 \times 10^{-4}$ & $4.4 \times 10^{-2}$ & $1.5 \times 10^{-2}$ & $1.7 \times 10^{-2}$ & $1.1 \times 10^{-2}$ & $-4.4 \times 10^{0}$ & $9.9 \times 10^{-1}$ \\
\hline 00-10 & 28 & $1.6 \times 10^{-4}$ & $5.2 \times 10^{-2}$ & $1.0 \times 10^{-2}$ & $1.3 \times 10^{-2}$ & $9.8 \times 10^{-3}$ & $-4.7 \times 10^{0}$ & $1.0 \times 10^{0}$ \\
\hline 00-15 & 25 & $2.9 \times 10^{-3}$ & $4.0 \times 10^{-2}$ & $8.7 \times 10^{-3}$ & $1.0 \times 10^{-2}$ & $7.6 \times 10^{-3}$ & $-4.8 \times 10^{0}$ & $6.1 \times 10^{-1}$ \\
\hline 00-25 & 23 & $1.9 \times 10^{-3}$ & $2.5 \times 10^{-2}$ & $5.5 \times 10^{-3}$ & $6.7 \times 10^{-3}$ & $4.9 \times 10^{-3}$ & $-5.2 \times 10^{0}$ & $6.2 \times 10^{-1}$ \\
\hline 00-40 & 22 & $1.2 \times 10^{-3}$ & $1.7 \times 10^{-2}$ & $3.6 \times 10^{-3}$ & $4.5 \times 10^{-3}$ & $3.3 \times 10^{-3}$ & $-5.6 \times 10^{0}$ & $6.5 \times 10^{-1}$ \\
\hline $00-60$ & 18 & $8.2 \times 10^{-4}$ & $5.2 \times 10^{-3}$ & $2.3 \times 10^{-3}$ & $2.4 \times 10^{-3}$ & $1.2 \times 10^{-3}$ & $-6.2 \times 10^{0}$ & $5.6 \times 10^{-1}$ \\
\hline
\end{tabular}

a The number of individual samples or when integrated, number of complete profiles.

NOTE: Specific Activity is decay corrected to 1998. 
Appendix A-4

241 Am Concentration in Soil, Utirik Atoll 
Appendix A-4.1. Americium-241 radionuclide concentrations summary for all soil profiles taken during the 1978 NMIRS and in 1993 on Utirik Island (061), Utirik Atoll.

\begin{tabular}{|c|c|c|c|c|c|c|c|c|c|}
\hline \multirow{2}{*}{$\begin{array}{c}\text { Soil } \\
\text { depth } \\
\text { (cm) }\end{array}$} & \multirow[b]{2}{*}{$\mathbf{N}^{\mathbf{a}}$} & \multirow[b]{2}{*}{ MDA's $^{b}$} & \multicolumn{5}{|c|}{ Bq g-1 dry wt. } & \multirow{2}{*}{$\begin{array}{l}\text { Mean } \\
\text { of logs }\end{array}$} & \multirow{2}{*}{$\begin{array}{l}\text { SD } \\
\text { of logs }\end{array}$} \\
\hline & & & Minimum & Maximum & Median & Mean & SD & & \\
\hline 00-05 & 182 & 63 & $6.1 \times 10^{-4}$ & $7.6 \times 10^{-2}$ & $1.1 \times 10^{-2}$ & $1.3 \times 10^{-2}$ & $1.1 \times 10^{-2}$ & $-4.6 \times 10^{0}$ & $7.9 \times 10^{-1}$ \\
\hline 05-10 & 171 & 92 & $1.6 \times 10^{-4}$ & $2.7 \times 10^{-2}$ & $5.4 \times 10^{-3}$ & $6.9 \times 10^{-3}$ & $5.4 \times 10^{-3}$ & $-5.3 \times 10^{0}$ & $8.8 \times 10^{-1}$ \\
\hline 10-15 & 173 & 134 & $1.3 \times 10^{-4}$ & $3.5 \times 10^{-2}$ & $3.8 \times 10^{-3}$ & $5.8 \times 10^{-3}$ & $6.0 \times 10^{-3}$ & $-5.6 \times 10^{0}$ & $1.0 \times 10^{0}$ \\
\hline $15-25$ & 172 & 150 & $2.0 \times 10^{-5}$ & $4.4 \times 10^{-2}$ & $3.5 \times 10^{-3}$ & $5.0 \times 10^{-3}$ & $6.2 \times 10^{-3}$ & $-5.8 \times 10^{0}$ & $1.2 \times 10^{0}$ \\
\hline $25-40$ & 170 & 150 & $4.6 \times 10^{-6}$ & $4.1 \times 10^{-2}$ & $3.8 \times 10^{-3}$ & $5.6 \times 10^{-3}$ & $6.9 \times 10^{-3}$ & $-5.9 \times 10^{0}$ & $1.6 \times 10^{0}$ \\
\hline $40-60$ & 162 & 147 & $1.8 \times 10^{-6}$ & $4.0 \times 10^{-2}$ & $3.4 \times 10^{-3}$ & $4.9 \times 10^{-3}$ & $5.4 \times 10^{-3}$ & $\begin{array}{l}-6.0 \times 10^{0} \\
-\end{array}$ & $1.7 \times 10^{0}$ \\
\hline 00-05 & 182 & 63 & $6.1 \times 10^{-4}$ & $7.6 \times 10^{-2}$ & $1.1 \times 10^{-2}$ & $1.3 \times 10^{-2}$ & $1.1 \times 10^{-2}$ & $-4.6 \times 10^{0}$ & $7.9 \times 10^{-1}$ \\
\hline 00-10 & 171 & 114 & $8.7 \times 10^{-4}$ & $4.2 \times 10^{-2}$ & $8.9 \times 10^{-3}$ & $1.0 \times 10^{-2}$ & $6.6 \times 10^{-3}$ & $-4.8 \times 10^{0}$ & $6.5 \times 10^{-1}$ \\
\hline 00-15 & 169 & 143 & $1.4 \times 10^{-3}$ & $3.2 \times 10^{-2}$ & $7.9 \times 10^{-3}$ & $8.9 \times 10^{-3}$ & $5.0 \times 10^{-3}$ & $-4.9 \times 10^{0}$ & $5.8 \times 10^{-1}$ \\
\hline 00-25 & 166 & 148 & $8.9 \times 10^{-4}$ & $2.4 \times 10^{-2}$ & $6.4 \times 10^{-3}$ & $7.4 \times 10^{-3}$ & $4.3 \times 10^{-3}$ & $-5.1 \times 10^{0}$ & $6.0 \times 10^{-1}$ \\
\hline $00-40$ & 161 & 145 & $5.8 \times 10^{-4}$ & $2.0 \times 10^{-2}$ & $5.8 \times 10^{-3}$ & $6.7 \times 10^{-3}$ & $4.1 \times 10^{-3}$ & $-5.2 \times 10^{0}$ & $6.6 \times 10^{-1}$ \\
\hline $00-60$ & 151 & 138 & $4.1 \times 10^{-4}$ & $1.9 \times 10^{-2}$ & $5.4 \times 10^{-3}$ & $6.1 \times 10^{-3}$ & $3.6 \times 10^{-3}$ & $-5.3 \times 10^{0}$ & $7.0 \times 10^{-1}$ \\
\hline
\end{tabular}

NOTE: Specific Activity is decay corrected to 1998.

a Number of individual samples or when integrated, number of complete profiles.

b Number of samples with minimum detection activities (MDA's) or when integrated, number of profiles that have one or more MDA's. 
Appendix A-4.2. Americium-241 radionuclide concentration summary for all soil profiles taken in 1993 on Utirik Island (06I), Utirik Atoll.

\begin{tabular}{|c|c|c|c|c|c|c|c|c|c|}
\hline \multirow{2}{*}{$\begin{array}{l}\text { Soil } \\
\text { depth } \\
\text { (cm) }\end{array}$} & \multirow[b]{2}{*}{$\mathbf{N}^{\mathbf{a}}$} & \multirow[b]{2}{*}{ MDA's $^{b}$} & \multicolumn{5}{|c|}{ Bq g-1 dry wt. } & \multirow{2}{*}{$\begin{array}{r}\text { Mean } \\
\text { of logs }\end{array}$} & \multirow{2}{*}{$\begin{array}{l}\text { SD } \\
\text { of } \operatorname{logs}\end{array}$} \\
\hline & & & Minimum & Maximum & Median & Mean & SD & & \\
\hline 00-05 & 154 & 59 & $6.1 \times 10^{-4}$ & $7.6 \times 10^{-2}$ & $1.2 \times 10^{-2}$ & $1.4 \times 10^{-2}$ & $1.1 \times 10^{-2}$ & $-4.5 \times 10^{0}$ & $8.1 \times 10^{-1}$ \\
\hline 05-10 & 143 & 88 & $4.8 \times 10^{-4}$ & $2.7 \times 10^{-2}$ & $5.7 \times 10^{-3}$ & $7.4 \times 10^{-3}$ & $5.4 \times 10^{-3}$ & $-5.2 \times 10^{0}$ & $7.4 \times 10^{-1}$ \\
\hline 10-15 & 145 & 127 & $7.7 \times 10^{-4}$ & $3.5 \times 10^{-2}$ & $4.5 \times 10^{-3}$ & $6.5 \times 10^{-3}$ & $6.2 \times 10^{-3}$ & $-5.4 \times 10^{0}$ & $7.9 \times 10^{-1}$ \\
\hline $15-25$ & 144 & 139 & $6.8 \times 10^{-4}$ & $4.4 \times 10^{-2}$ & $3.9 \times 10^{-3}$ & $5.8 \times 10^{-3}$ & $6.5 \times 10^{-3}$ & $-5.5 \times 10^{0}$ & $7.6 \times 10^{-1}$ \\
\hline $25-40$ & 142 & 141 & $9.4 \times 10^{-4}$ & $4.1 \times 10^{-2}$ & $4.2 \times 10^{-3}$ & $6.5 \times 10^{-3}$ & $7.2 \times 10^{-3}$ & $-5.4 \times 10^{0}$ & $7.7 \times 10^{-1}$ \\
\hline $40-60$ & 137 & 136 & $8.6 \times 10^{-4}$ & $4.0 \times 10^{-2}$ & $3.9 \times 10^{-3}$ & $5.6 \times 10^{-3}$ & $5.5 \times 10^{-3}$ & $-5.5 \times 10^{0}$ & $7.0 \times 10^{-1}$ \\
\hline 00-05 & 154 & 59 & $6.1 \times 10^{-4}$ & $7.6 \times 10^{-2}$ & $1.2 \times 10^{-2}$ & $1.4 \times 10^{-2}$ & $1.1 \times 10^{-2}$ & $-4.5 \times 10^{0}$ & $8.1 \times 10^{-1}$ \\
\hline 00-10 & 143 & 107 & $8.7 \times 10^{-4}$ & $4.2 \times 10^{-2}$ & $1.0 \times 10^{-2}$ & $1.1 \times 10^{-2}$ & $6.7 \times 10^{-3}$ & $-4.7 \times 10^{0}$ & $6.3 \times 10^{-1}$ \\
\hline 00-15 & 141 & 133 & $1.4 \times 10^{-3}$ & $3.2 \times 10^{-2}$ & $8.7 \times 10^{-3}$ & $9.7 \times 10^{-3}$ & $5.0 \times 10^{-3}$ & $-4.8 \times 10^{0}$ & $5.2 \times 10^{-1}$ \\
\hline 00-25 & 138 & 137 & $2.7 \times 10^{-3}$ & $2.4 \times 10^{-2}$ & $7.0 \times 10^{-3}$ & $8.2 \times 10^{-3}$ & $4.2 \times 10^{-3}$ & $-4.9 \times 10^{0}$ & $4.7 \times 10^{-1}$ \\
\hline $00-40$ & 133 & 133 & $2.9 \times 10^{-3}$ & $2.0 \times 10^{-2}$ & $6.7 \times 10^{-3}$ & $7.6 \times 10^{-3}$ & $3.9 \times 10^{-3}$ & $-5.0 \times 10^{0}$ & $4.7 \times 10^{-1}$ \\
\hline $00-60$ & 126 & 126 & $2.6 \times 10^{-3}$ & $1.9 \times 10^{-2}$ & $6.1 \times 10^{-3}$ & $6.9 \times 10^{-3}$ & $3.3 \times 10^{-3}$ & $-5.1 \times 10^{0}$ & $4.4 \times 10^{-1}$ \\
\hline
\end{tabular}

NOTE: Specific Activity is decay corrected to 1998.

a Number of individual samples or when integrated, number of complete profiles.

b Number of samples with minimum detection activities (MDA's) or when integrated, number of profiles that have one or more MDA's. 
Appendix A-4.3. Americium-241 radionuclide concentration summary for all soil profiles taken during the 1978 NMIRS on Utirik Island (06I), Utirik Atoll.

\begin{tabular}{|c|c|c|c|c|c|c|c|c|c|}
\hline \multirow{2}{*}{$\begin{array}{l}\text { Soil } \\
\text { Depth } \\
\text { (cm) }\end{array}$} & \multirow[b]{2}{*}{$\mathbf{N}^{\mathbf{a}}$} & \multirow[b]{2}{*}{ MDA's $^{b}$} & \multicolumn{5}{|c|}{ Bq $g^{-1}$ dry wt. } & \multirow{2}{*}{$\begin{array}{l}\text { Mean } \\
\text { of logs }\end{array}$} & \multirow{2}{*}{$\begin{array}{c}\text { SD } \\
\text { of logs }\end{array}$} \\
\hline & & & Minimum & Maximum & Median & Mean & SD & & \\
\hline 00-05 & 28 & 4 & $1.7 \times 10^{-3}$ & $2.0 \times 10^{-2}$ & $8.3 \times 10^{-3}$ & $8.4 \times 10^{-3}$ & $4.7 \times 10^{-3}$ & $-4.9 \times 10^{0}$ & $5.9 \times 10^{-1}$ \\
\hline 05-10 & 28 & 4 & $1.6 \times 10^{-4}$ & $2.5 \times 10^{-2}$ & $3.9 \times 10^{-3}$ & $4.2 \times 10^{-3}$ & $4.9 \times 10^{-3}$ & $-6.0 \times 10^{0}$ & $1.2 \times 10^{0}$ \\
\hline 10-15 & 28 & 7 & $1.3 \times 10^{-4}$ & $7.9 \times 10^{-3}$ & $1.5 \times 10^{-3}$ & $2.0 \times 10^{-3}$ & $1.9 \times 10^{-3}$ & $-6.8 \times 10^{0}$ & $1.2 \times 10^{0}$ \\
\hline $15-25$ & 28 & 11 & $2.0 \times 10^{-5}$ & $6.4 \times 10^{-3}$ & $5.1 \times 10^{-4}$ & $1.2 \times 10^{-3}$ & $1.6 \times 10^{-3}$ & $-7.7 \times 10^{0}$ & $1.6 \times 10^{0}$ \\
\hline $25-40$ & 28 & 9 & $4.6 \times 10^{-6}$ & $4.8 \times 10^{-3}$ & $1.7 \times 10^{-4}$ & $1.2 \times 10^{-3}$ & $1.5 \times 10^{-3}$ & $-8.4 \times 10^{0}$ & $2.3 \times 10^{0}$ \\
\hline $40-60$ & 25 & 11 & $1.8 \times 10^{-6}$ & $4.1 \times 10^{-3}$ & $8.8 \times 10^{-5}$ & $7.7 \times 10^{-4}$ & $1.0 \times 10^{-3}$ & $-8.9 \times 10^{0}$ & $2.4 \times 10^{0}$ \\
\hline 00-05 & 28 & 4 & $1.7 \times 10^{-3}$ & $2.0 \times 10^{-2}$ & $8.3 \times 10^{-3}$ & $8.4 \times 10^{-3}$ & $4.7 \times 10^{-3}$ & $-4.9 \times 10^{0}$ & $5.9 \times 10^{-1}$ \\
\hline 00-10 & 28 & 7 & $1.7 \times 10^{-3}$ & $2.2 \times 10^{-2}$ & $5.5 \times 10^{-3}$ & $6.3 \times 10^{-3}$ & $4.0 \times 10^{-3}$ & $-5.2 \times 10^{0}$ & $5.6 \times 10^{-1}$ \\
\hline 00-15 & 28 & 10 & $1.4 \times 10^{-3}$ & $1.8 \times 10^{-2}$ & $4.4 \times 10^{-3}$ & $4.9 \times 10^{-3}$ & $3.1 \times 10^{-3}$ & $-5.5 \times 10^{0}$ & $5.5 \times 10^{-1}$ \\
\hline 00-25 & 28 & 11 & $8.9 \times 10^{-4}$ & $1.1 \times 10^{-2}$ & $2.9 \times 10^{-3}$ & $3.4 \times 10^{-3}$ & $2.1 \times 10^{-3}$ & $-5.8 \times 10^{0}$ & $5.8 \times 10^{-1}$ \\
\hline $00-40$ & 28 & 12 & $5.8 \times 10^{-4}$ & $7.3 \times 10^{-3}$ & $2.2 \times 10^{-3}$ & $2.6 \times 10^{-3}$ & $1.6 \times 10^{-3}$ & $-6.1 \times 10^{0}$ & $6.2 \times 10^{-1}$ \\
\hline $00-60$ & 25 & 12 & $4.1 \times 10^{-4}$ & $4.7 \times 10^{-3}$ & $1.7 \times 10^{-3}$ & $1.8 \times 10^{-3}$ & $1.0 \times 10^{-3}$ & $-6.5 \times 10^{0}$ & $5.9 \times 10^{-1}$ \\
\hline
\end{tabular}

NOTE Specific Activity is decay corrected to 1998.

a Number of individual samples or when integrated, number of complete profiles.

b Number of samples with minimum detection activities (MDA's) or when integrated, number of profiles that have one or more MDA's. 
Appendix A-4.4. Americium-241 radionuclide concentration summary for all soil profiles taken in the interior area in 1993 on Utirik Island (06I), Utirik Atoll.

\begin{tabular}{|c|c|c|c|c|c|c|c|c|c|}
\hline \multirow{2}{*}{$\begin{array}{l}\text { Soil } \\
\text { Depth } \\
\text { (cm) }\end{array}$} & \multirow[b]{2}{*}{$\mathrm{N}^{\mathrm{a}}$} & \multirow[b]{2}{*}{ MDA's } & \multicolumn{5}{|c|}{ Bq g-1 dry wt. } & \multirow{2}{*}{$\begin{array}{l}\text { Mean } \\
\text { of logs }\end{array}$} & \multirow{2}{*}{$\begin{array}{l}\text { SD } \\
\text { of logs }\end{array}$} \\
\hline & & & b Minimum & Maximum & Median & Mean & SD & & \\
\hline 00-05 & 130 & 42 & $1.4 \times$ & $7.6 \times 10^{-2}$ & $1.3 \times 1$ & $1.6 \times 1$ & $1.2 \times 10^{-2}$ & $-4.4 \times 10^{0}$ & $6.9>$ \\
\hline 05-10 & 127 & 75 & $8.4 \times 10^{-4}$ & $2.7 \times 10^{-2}$ & $5.7 \times 10^{-3}$ & $7.3 \times 10^{-3}$ & $5.2 \times 10^{-3}$ & $-5.2 \times 10^{0}$ & $7.1 \times 10^{-1}$ \\
\hline $10-15$ & 129 & 115 & $7.7 \times 10^{-4}$ & $3.5 \times 10^{-2}$ & $4.2 \times 10^{-3}$ & $6.0 \times 10^{-3}$ & $5.6 \times 10^{-3}$ & $-5.4 \times 10^{0}$ & $7.7 \times 10^{-1}$ \\
\hline $15-25$ & 127 & 125 & $6.8 \times 10^{-4}$ & $4.4 \times 10^{-2}$ & $3.8 \times 10^{-3}$ & $5.8 \times$ & $6.9 \times 10^{-3}$ & $-5.5 \times 10^{0}$ & $7.8 \times 10^{-1}$ \\
\hline $25-40$ & 126 & 126 & $9.4 \times$ & $4.1 \times 10^{-2}$ & $4.2 \times$ & $6.6 \times$ & $7.6 \times 1$ & $-5.4 \times 10^{0}$ & $8.0 \times 10^{-1}$ \\
\hline $40-60$ & 122 & 121 & $8.6 \times 10^{-4}$ & $4.0 \times 10^{-2}$ & $3.9 \times 10^{-3}$ & $5.7 \times 1$ & $5.8 \times 10^{-3}$ & $-5.5 \times 10^{0}$ & $7.0 \times 10^{-1}$ \\
\hline 00-05 & 130 & 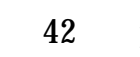 & & & & 1 & & & \\
\hline 00-10 & 127 & 93 & $2.1 \times 10^{-3}$ & $4.2 \times 10^{-2}$ & $1.0 \times 10^{-2}$ & $1.2 \times 10^{-2}$ & $6.8 \times 10^{-3}$ & $-4.6 \times 10^{0}$ & $5.8 \times 10^{-1}$ \\
\hline 00-15 & 125 & 118 & $3.0 \times 10^{-3}$ & $3.2 \times 10^{-2}$ & $8.6 \times 10^{-3}$ & $9.8 \times 10^{-3}$ & $4.9 \times 10^{-3}$ & $-4.7 \times 10^{0}$ & $4.8 \times 10^{-1}$ \\
\hline $00-25$ & 122 & 121 & $2.8 \times 10^{-3}$ & $2.4 \times 10^{-2}$ & $7.0 \times 10^{-3}$ & $8.2 \times 10^{-3}$ & $4.2 \times 10^{-3}$ & $-4.9 \times 10^{0}$ & $4.6 \times 10^{-1}$ \\
\hline $00-40$ & 118 & 118 & $2.9 \times 10^{-3}$ & $2.0 \times 10^{-2}$ & $6.7 \times 10^{-3}$ & $7.6 \times 10^{-3}$ & $4.0 \times 10^{-3}$ & $-5.0 \times 10^{0}$ & $4.7 \times 10^{-1}$ \\
\hline $00-60$ & 112 & 112 & $3.0 \times 10^{-3}$ & $1.9 \times 10^{-2}$ & $6.1 \times 10^{-3}$ & $7.0 \times 10^{-3}$ & $3.4 \times 10^{-3}$ & $-5.1 \times 10^{0}$ & $4.4 \times 10^{-1}$ \\
\hline
\end{tabular}

NOTE: Specific Activity is decay corrected to 1998.

a Number of individual samples or when integrated, number of complete profiles.

b Number of samples with minimum detection activities (MDA's) or when integrated, number of profiles that have one or more MDA's.

Table A-4.5. Americium-241 radionuclide concentration summary for all soil profiles taken in the village area in 1993 on Utirik Island (06I), Utirik Atoll.

\begin{tabular}{|c|c|c|c|c|c|c|c|c|c|}
\hline \multirow{2}{*}{$\begin{array}{l}\text { Soil } \\
\text { Depth } \\
\text { (cm) }\end{array}$} & \multirow[b]{2}{*}{$\mathbf{N}^{\mathbf{a}}$} & \multirow[b]{2}{*}{ MDA's $^{\mathrm{b}}$} & \multicolumn{5}{|c|}{ Bq g-1 dry wt. } & \multirow{2}{*}{$\begin{array}{l}\text { Mean } \\
\text { of logs }\end{array}$} & \multirow{2}{*}{$\begin{array}{c}\text { SD } \\
\text { of logs }\end{array}$} \\
\hline & & & Minimum & Maximum & Median & Mean & SD & & \\
\hline 00-05 & 17 & 10 & $6.1 \times 10^{-4}$ & $1.6 \times 10^{-2}$ & $6.2 \times 10$ & $7.0 \times 10^{-3}$ & $4.7 \times 10^{-3}$ & $-5.3 \times 10^{0}$ & $9.1 \times 10^{-1}$ \\
\hline 05-10 & 16 & 13 & $4.8 \times 10^{-4}$ & $2.4 \times 10^{-2}$ & $7.0 \times 10^{-3}$ & $8.5 \times 10^{-3}$ & $6.9 \times 10^{-3}$ & $-5.1 \times 10^{0}$ & $1.0 \times 10^{0}$ \\
\hline $10-15$ & 16 & 12 & $2.4 \times 10^{-3}$ & $3.5 \times 10^{-2}$ & $6.5 \times 10^{-3}$ & $1.1 \times 10^{-2}$ & $9.3 \times 10^{-3}$ & $-4.8 \times 10^{0}$ & $7.8 \times 10^{-1}$ \\
\hline $15-25$ & 17 & 14 & $1.7 \times 10^{-3}$ & $1.2 \times 10^{-2}$ & $5.0 \times 10^{-3}$ & $6.0 \times 10^{-3}$ & $3.4 \times 10^{-3}$ & $-5.3 \times 10^{0}$ & $6.0 \times 10^{-1}$ \\
\hline $25-40$ & 16 & 15 & $2.4 \times 10^{-3}$ & $1.1 \times 10^{-2}$ & $5.3 \times 10^{-3}$ & $6.0 \times 10^{-3}$ & $2.6 \times 10^{-3}$ & $-5.2 \times 10^{0}$ & $4.4 \times 10^{-1}$ \\
\hline $40-60$ & 15 & 15 & $1.3 \times 10^{-3}$ & $1.1 \times 10^{-2}$ & $3.6 \times 10^{-3}$ & $4.7 \times 10^{-3}$ & $3.0 \times 10^{-3}$ & $-5.6 \times 10^{0}$ & $6.8 \times 10^{-1}$ \\
\hline 00-05 & 17 & 10 & $6.1 \times 10^{-4}$ & $1.6 \times 10^{-2}$ & $6.2 \times 10^{-3}$ & $7.0 \times 10^{-3}$ & $4.7 \times 10^{-3}$ & $-5.3 \times 10^{0}$ & $9.1 \times 10^{-1}$ \\
\hline 00-10 & 16 & 14 & $8.7 \times 10^{-4}$ & $1.7 \times 10^{-2}$ & $7.5 \times 10^{-3}$ & $7.6 \times 10^{-3}$ & $4.9 \times 10^{-3}$ & $-5.1 \times 10^{0}$ & $8.2 \times 10^{-1}$ \\
\hline 00-15 & 16 & 15 & $1.4 \times 10^{-3}$ & $1.8 \times 10^{-2}$ & $8.9 \times 10^{-3}$ & $8.7 \times 10^{-3}$ & $5.4 \times 10^{-3}$ & $-5.0 \times 10^{0}$ & $7.4 \times 10^{-1}$ \\
\hline 00-25 & 16 & 16 & $2.7 \times 10^{-3}$ & $1.5 \times 10^{-2}$ & $7.0 \times 10^{-3}$ & $7.7 \times 10^{-3}$ & $3.9 \times 10^{-3}$ & $-5.0 \times 10^{0}$ & $5.4 \times 10^{-1}$ \\
\hline $00-40$ & 15 & 15 & $3.3 \times 10^{-3}$ & $1.2 \times 10^{-2}$ & $6.6 \times 10^{-3}$ & $7.2 \times 10^{-3}$ & $2.8 \times 1$ & $-5.0 \times 10^{0}$ & $4.2 \times 10^{-1}$ \\
\hline $00-60$ & 14 & 14 & $2.6 \times 10^{-3}$ & $9.8 \times 10^{-3}$ & $6.1 \times 10^{-3}$ & $6.6 \times 10^{-3}$ & $2.4 \times 10^{-3}$ & $-5.1 \times 10^{0}$ & $4.2 \times 10^{-1}$ \\
\hline
\end{tabular}

NOTE: Specific Activity is decay corrected to 1998.

a Number of individual samples or when integrated, number of complete profiles.

b Number of samples with minimum detection activities (MDA's) or when integrated, number of profiles that have one or more MDA's. 
Appendix A-4.6. Americium-241 radionuclide concentration summary for all soil profiles taken during the 1978 NMIRS in 1994 on Bikrak Island (03I), Utirik Atoll.

\begin{tabular}{lccccccccc}
\hline \multirow{2}{*}{$\begin{array}{c}\text { Soil } \\
\text { depth } \\
\text { (cm) }\end{array}$} & $\mathbf{N}^{\mathbf{a}}$ & MDA's $^{\mathbf{b}}$ & Minimum & Maximum & Median & Mean & SD & $\begin{array}{c}\text { Mean } \\
\text { of logs }\end{array}$ & $\begin{array}{c}\text { SD } \\
\text { of logs }\end{array}$ \\
\hline 00-05 & 20 & 1 & $3.1 \times 10^{-3}$ & $2.7 \times 10^{-2}$ & $8.6 \times 10^{-3}$ & $1.1 \times 10^{-2}$ & $6.4 \times 10^{-3}$ & $-4.7 \times 10^{0}$ & $5.9 \times 10^{-1}$ \\
$05-10$ & 21 & 10 & $8.7 \times 10^{-4}$ & $2.0 \times 10^{-2}$ & $5.1 \times 10^{-3}$ & $6.6 \times 10^{-3}$ & $5.5 \times 10^{-3}$ & $-5.4 \times 10^{0}$ & $9.6 \times 10^{-1}$ \\
$10-15$ & 20 & 17 & $7.0 \times 10^{-4}$ & $3.6 \times 10^{-2}$ & $3.1 \times 10^{-3}$ & $6.1 \times 10^{-3}$ & $8.3 \times 10^{-3}$ & $-5.6 \times 10^{0}$ & $9.5 \times 10^{-1}$ \\
$15-25$ & 20 & 19 & $7.7 \times 10^{-4}$ & $9.6 \times 10^{-3}$ & $3.4 \times 10^{-3}$ & $3.7 \times 10^{-3}$ & $2.0 \times 10^{-3}$ & $-5.7 \times 10^{0}$ & $5.7 \times 10^{-1}$ \\
$25-40$ & 19 & 19 & $7.2 \times 10^{-4}$ & $1.1 \times 10^{-2}$ & $2.6 \times 10^{-3}$ & $3.6 \times 10^{-3}$ & $2.7 \times 10^{-3}$ & $-5.9 \times 10^{0}$ & $7.3 \times 10^{-1}$ \\
$40-60$ & 21 & 21 & $8.3 \times 10^{-4}$ & $2.3 \times 10^{-2}$ & $2.5 \times 10^{-3}$ & $3.6 \times 10^{-3}$ & $4.8 \times 10^{-3}$ & $-6.0 \times 10^{0}$ & $7.8 \times 10^{-1}$ \\
& & & & & & & & \\
$00-05$ & 20 & 1 & $3.1 \times 10^{-3}$ & $2.7 \times 10^{-2}$ & $8.6 \times 10^{-3}$ & $1.1 \times 10^{-2}$ & $6.4 \times 10^{-3}$ & $-4.7 \times 10^{0}$ & $5.9 \times 10^{-1}$ \\
$00-10$ & 19 & 10 & $2.1 \times 10^{-3}$ & $2.4 \times 10^{-2}$ & $8.4 \times 10^{-3}$ & $8.8 \times 10^{-3}$ & $5.3 \times 10^{-}$ & $-4.9 \times 10^{0}$ & $6.0 \times 10^{-1}$ \\
$00-15$ & 19 & 16 & $1.9 \times 10^{-3}$ & $2.2 \times 10^{-2}$ & $6.6 \times 10^{-3}$ & $8.0 \times 10^{-3}$ & $4.9 \times 10^{-3}$ & $-5.0 \times 10^{0}$ & $6.1 \times 10^{-1}$ \\
$00-25$ & 19 & 18 & $2.1 \times 10^{-3}$ & $1.4 \times 10^{-2}$ & $5.1 \times 10^{-3}$ & $6.4 \times 10^{-3}$ & $3.1 \times 10^{-3}$ & $-5.2 \times 10^{0}$ & $4.9 \times 10^{-1}$ \\
$00-40$ & 19 & 19 & $2.0 \times 10^{-3}$ & $1.0 \times 10^{-2}$ & $4.9 \times 10^{-3}$ & $5.3 \times 10^{-3}$ & $2.1 \times 10^{-3}$ & $-5.3 \times 10^{0}$ & $3.9 \times 10^{-1}$ \\
$00-60$ & 19 & 19 & $1.7 \times 10^{-3}$ & $1.1 \times 10^{-2}$ & $4.5 \times 10^{-3}$ & $4.8 \times 10^{-3}$ & $2.2 \times 10^{-3}$ & $-5.4 \times 10^{0}$ & $4.2 \times 10^{-1}$ \\
\hline
\end{tabular}

NOTE: Specific Activity is decay corrected to 1998.

a Number of individual samples or when integrated, number of complete profiles.

b Number of samples with minimum detection activities (MDA's) or when integrated, number of profiles that have one or more MDA's. 
Appendix A-4.7. Americium-241 radionuclide concentration summary for all soil profiles in 1994 on Bikrak Island (03I), Utirik Atoll.

\begin{tabular}{|c|c|c|c|c|c|c|c|c|c|}
\hline \multirow{2}{*}{$\begin{array}{l}\text { Soil } \\
\text { depth } \\
(\mathrm{cm})\end{array}$} & \multirow[b]{2}{*}{$\mathbf{N}^{\mathrm{a}}$} & \multirow[b]{2}{*}{$\operatorname{MDA}^{\prime}{ }^{b}$} & \multirow[b]{2}{*}{ Minimum } & \multicolumn{4}{|c|}{ Bq $g^{-1}$ dry wt. } & \multirow{2}{*}{$\begin{array}{l}\text { Mean } \\
\text { of logs }\end{array}$} & \multirow{2}{*}{$\begin{array}{c}\text { SD } \\
\text { of logs }\end{array}$} \\
\hline & & & & Maximum & Median & Mean & SD & & \\
\hline 00-05 & 19 & 1 & $3.1 \times 10^{-3}$ & $2.7 \times 10^{-2}$ & $8.6 \times 10^{-3}$ & $1.1 \times 10^{-2}$ & $6.4 \times 10^{-3}$ & $-4.7 \times 10^{0}$ & $5.8 \times 10^{-1}$ \\
\hline $05-10$ & 19 & 9 & $9.1 \times 10^{-4}$ & $2.0 \times 10^{-2}$ & $5.1 \times 10^{-3}$ & $6.8 \times 10^{-3}$ & $5.6 \times 10^{-3}$ & $-5.4 \times 10^{0}$ & $9.3 \times 10^{-1}$ \\
\hline $10-15$ & 19 & 16 & $9.2 \times 10^{-4}$ & $3.6 \times 10^{-2}$ & $3.1 \times 10^{-3}$ & $6.4 \times 10^{-3}$ & $8.4 \times 10^{-3}$ & $-5.5 \times 10^{0}$ & $8.9 \times 10^{-1}$ \\
\hline $15-25$ & 19 & 18 & $1.2 \times 10^{-3}$ & $9.6 \times 10^{-3}$ & $3.4 \times 10^{-3}$ & $3.9 \times 10^{-3}$ & $1.9 \times 10^{-3}$ & $-5.7 \times 10^{0}$ & $4.7 \times 10^{-1}$ \\
\hline $25-40$ & 19 & 19 & $7.2 \times 10^{-4}$ & $1.1 \times 10^{-2}$ & $2.6 \times 10^{-3}$ & $3.6 \times 10^{-3}$ & $2.7 \times 10^{-3}$ & $-5.9 \times 10^{0}$ & $7.3 \times 10^{-1}$ \\
\hline $40-60$ & 19 & 19 & $8.3 \times 10^{-4}$ & $2.3 \times 10^{-2}$ & $2.5 \times 10^{-3}$ & $3.9 \times 10^{-3}$ & $5.0 \times 10^{-3}$ & $-5.9 \times 10^{0}$ & $7.7 \times 10^{-1}$ \\
\hline 00-05 & 19 & 1 & $3.1 \times 10^{-3}$ & $2.7 \times 10^{-2}$ & $8.6 \times 10^{-3}$ & $1.1 \times 10^{-2}$ & $6.4 \times 10^{-3}$ & $-4.7 \times 10^{0}$ & $5.8 \times 10^{-1}$ \\
\hline $00-10$ & 19 & 10 & $2.1 \times 10^{-3}$ & $2.4 \times 10^{-2}$ & $8.4 \times 10^{-3}$ & $8.8 \times 10^{-3}$ & $5.3 \times 10^{-3}$ & $-4.9 \times 10^{0}$ & $6.0 \times 10^{-1}$ \\
\hline 00-15 & 19 & 16 & $1.9 \times 10^{-3}$ & $2.2 \times 10^{-2}$ & $6.6 \times 10^{-3}$ & $8.0 \times 10^{-3}$ & $4.9 \times 10^{-3}$ & $-5.0 \times 10^{0}$ & $6.1 \times 10^{-1}$ \\
\hline $00-25$ & 19 & 18 & $2.1 \times 10^{-3}$ & $1.4 \times 10^{-2}$ & $5.1 \times 10^{-3}$ & $6.4 \times 10^{-3}$ & $3.1 \times 10^{-3}$ & $-5.2 \times 10^{0}$ & $4.9 \times 10^{-1}$ \\
\hline $00-40$ & 19 & 19 & $2.0 \times 10^{-3}$ & $1.0 \times 10^{-2}$ & $4.9 \times 10^{-3}$ & $5.3 \times 10^{-3}$ & $2.1 \times 10^{-3}$ & $-5.3 \times 10^{0}$ & $3.9 \times 10^{-1}$ \\
\hline $00-60$ & 19 & 19 & $1.7 \times 10^{-3}$ & $1.1 \times 10^{-2}$ & $4.5 \times 10^{-3}$ & $4.8 \times 10^{-3}$ & $2.2 \times 10^{-3}$ & $-5.4 \times 10^{0}$ & $4.2 \times 10^{-1}$ \\
\hline
\end{tabular}

NOTE: Specific Activity is decay corrected to 1998.

a Number of individual samples or when integrated, number of complete profiles.

${ }^{b}$ Number of samples with minimum detection activities (MDA's) or when integrated, number of profiles that have one or more MDA's. 
Appendix A-4.8. Americium-241 radionuclide concentration summary for all soil profiles taken during the 1978 NMIRS on Bikrak Island (03I), Utirik Atoll.

\begin{tabular}{|c|c|c|c|c|c|c|c|c|c|}
\hline \multirow{2}{*}{$\begin{array}{l}\text { Soil } \\
\text { Depth } \\
\text { (cm) }\end{array}$} & \multirow[b]{2}{*}{$\mathbf{N}^{\mathbf{a}}$} & \multirow[b]{2}{*}{ MDA's $^{b}$} & \multirow[b]{2}{*}{ Minimum } & \multicolumn{4}{|c|}{ Bq $g^{-1}$ dry wt. } & \multirow{2}{*}{$\begin{array}{r}\text { Mean } \\
\text { of logs }\end{array}$} & \multirow{2}{*}{$\begin{array}{l}\text { SD } \\
\text { of } \log s\end{array}$} \\
\hline & & & & Maximum & Median & Mean & SD & & \\
\hline 00-05 & 1 & 0 & $4.5 \times 10^{-3}$ & $4.5 \times 10^{-3}$ & $4.5 \times 10^{-3}$ & $4.5 \times 10^{-3}$ & $0.0 \times 10^{0}$ & $-5.4 \times 10^{0}$ & $0.0 \times 10^{0}$ \\
\hline 05-10 & 2 & 1 & $8.7 \times 10^{-4}$ & $7.9 \times 10^{-3}$ & $4.4 \times 10^{-3}$ & $4.4 \times 10^{-3}$ & $5.0 \times 10^{-3}$ & $-6.0 \times 10^{0}$ & $1.6 \times 10^{0}$ \\
\hline 10-15 & 1 & 1 & $7.0 \times 10^{-4}$ & $7.0 \times 10^{-4}$ & $7.0 \times 10^{-4}$ & $7.0 \times 10^{-4}$ & $0.0 \times 10^{0}$ & $-7.3 \times 10^{0}$ & $0.0 \times 10^{0}$ \\
\hline $15-25$ & 1 & 1 & $7.7 \times 10^{-4}$ & $7.7 \times 10^{-4}$ & $7.7 \times 10^{-4}$ & $7.7 \times 10^{-4}$ & $0.0 \times 10^{0}$ & $-7.2 \times 10^{0}$ & $0.0 \times 10^{0}$ \\
\hline $25-40$ & 0 & 0 & $0.0 \times 10^{0}$ & $0.0 \times 10^{0}$ & $0.0 \times 10^{0}$ & $0.0 \times 10^{0}$ & $0.0 \times 10^{0}$ & $0.0 \times 10^{0}$ & $0.0 \times 10^{0}$ \\
\hline $40-60$ & 2 & 2 & $9.8 \times 10^{-4}$ & $1.3 \times 10^{-3}$ & $1.1 \times 10^{-3}$ & $1.1 \times 10^{-3}$ & $2.2 \times 10^{-4}$ & $-6.8 \times 10^{0}$ & $1.9 \times 10^{-1}$ \\
\hline 00-05 & 1 & 0 & $4.5 \times 10^{-3}$ & $4.5 \times 10^{-3}$ & $4.5 \times 10^{-3}$ & $4.5 \times 10^{-3}$ & $0.0 \times 10^{0}$ & $-5.4 \times 10^{0}$ & $0.0 \times 10^{0}$ \\
\hline 00-10 & 0 & 0 & $0.0 \times 10^{0}$ & $0.0 \times 10^{0}$ & $0.0 \times 10^{0}$ & $0.0 \times 10^{0}$ & $0.0 \times 10^{0}$ & $0.0 \times 10^{0}$ & $0.0 \times 10^{0}$ \\
\hline 00-15 & 0 & 0 & $0.0 \times 10^{0}$ & $0.0 \times 10^{0}$ & $0.0 \times 10^{0}$ & $0.0 \times 10^{0}$ & $0.0 \times 10^{0}$ & $0.0 \times 10^{0}$ & $0.0 \times 10^{0}$ \\
\hline 00-25 & 0 & 0 & $0.0 \times 10^{0}$ & $0.0 \times 10^{0}$ & $0.0 \times 10^{0}$ & $0.0 \times 10^{0}$ & $0.0 \times 10^{0}$ & $0.0 \times 10^{0}$ & $0.0 \times 10^{0}$ \\
\hline 00-40 & 0 & 0 & $0.0 \times 10^{0}$ & $0.0 \times 10^{0}$ & $0.0 \times 10^{0}$ & $0.0 \times 10^{0}$ & $0.0 \times 10^{0}$ & $0.0 \times 10^{0}$ & $0.0 \times 10^{0}$ \\
\hline $00-60$ & 0 & 0 & $0.0 \times 10^{0}$ & $0.0 \times 10^{0}$ & $0.0 \times 10^{0}$ & $0.0 \times 10^{0}$ & $0.0 \times 10^{0}$ & $0.0 \times 10^{0}$ & $0.0 \times 10^{0}$ \\
\hline
\end{tabular}

NOTE: Specific Activity is decay corrected to 1998.

a Number of individual samples or when integrated, number of complete profiles.

b Number of samples with minimum detection activities (MDA's) or when integrated, number of profiles that have one or more MDA's. 
Appendix A-4.9. Americium-241 radionuclide concentration summary for all soil profiles taken during the 1978 NMIRS and in 1994 on Aon Island (08I), Utirik Atoll.

\begin{tabular}{|c|c|c|c|c|c|c|c|c|c|}
\hline \multirow{2}{*}{$\begin{array}{l}\text { Soil } \\
\text { depth } \\
\text { (cm) }\end{array}$} & \multirow[b]{2}{*}{$\mathrm{N}^{\mathrm{a}}$} & \multirow[b]{2}{*}{ MDA's $^{b}$} & \multicolumn{5}{|c|}{ Bq g ${ }^{-1}$ dry wt. } & \multirow{2}{*}{$\begin{array}{l}\text { Mean } \\
\text { of logs }\end{array}$} & \multirow{2}{*}{$\begin{array}{l}\text { SD } \\
\text { of logs }\end{array}$} \\
\hline & & & Minimum & Maximum & Median & Mean & SD & & \\
\hline 00-05 & 35 & 11 & $1.6 \times 10^{-3}$ & $5.0 \times 10^{-2}$ & $9.2 \times 10^{-3}$ & $1.3 \times 10^{-2}$ & $1.1 \times 10^{-2}$ & $-4.6 \times 10^{0}$ & $7.1 \times 10^{-1}$ \\
\hline 05-10 & 35 & 24 & $1.2 \times 10^{-3}$ & $2.4 \times 10^{-2}$ & $5.5 \times 10^{-3}$ & $6.5 \times 10^{-3}$ & $4.9 \times 10^{-3}$ & $-5.3 \times 10^{0}$ & $7.0 \times 10^{-1}$ \\
\hline $10-15$ & 35 & 32 & $1.3 \times 10^{-3}$ & $4.0 \times 10^{-2}$ & $4.5 \times 10^{-3}$ & $6.3 \times 10^{-3}$ & $6.7 \times 10^{-3}$ & $-5.4 \times 10^{0}$ & $7.2 \times 10^{-1}$ \\
\hline $15-25$ & 35 & 34 & $6.7 \times 10^{-4}$ & $3.4 \times 10^{-2}$ & $2.5 \times 10^{-3}$ & $4.4 \times 10^{-3}$ & $5.8 \times 10^{-3}$ & $-5.8 \times 10^{0}$ & $7.7 \times 10^{-1}$ \\
\hline $25-40$ & 34 & 34 & $7.7 \times 10^{-4}$ & $1.4 \times 10^{-2}$ & $3.5 \times 10^{-3}$ & $3.7 \times 10^{-3}$ & $2.8 \times 10^{-3}$ & $-5.9 \times 10^{0}$ & $7.3 \times 10^{-1}$ \\
\hline $40-60$ & 27 & 27 & $1.0 \times 10^{-3}$ & $2.2 \times 10^{-2}$ & $2.1 \times 10^{-3}$ & $3.2 \times 10^{-3}$ & $4.0 \times 10^{-3}$ & $-6.0 \times 10^{0}$ & $6.4 \times 10^{-1}$ \\
\hline 00-05 & 35 & 11 & $1.6 \times 10^{-3}$ & $5.0 \times 10^{-2}$ & $9.2 \times 10^{-3}$ & $1.3 \times 10^{-2}$ & $1.1 \times 10^{-2}$ & $-4.6 \times 10^{0}$ & $7.1 \times 10^{-1}$ \\
\hline 00-10 & 35 & 26 & $3.0 \times 10^{-3}$ & $3.1 \times 10^{-2}$ & $7.3 \times 10^{-3}$ & $9.9 \times 10^{-3}$ & $6.7 \times 10^{-3}$ & $-4.8 \times 10^{0}$ & $5.6 \times 10^{-1}$ \\
\hline 00-15 & 35 & 34 & $3.1 \times 10^{-3}$ & $2.2 \times 10^{-2}$ & $7.2 \times 10^{-3}$ & $8.7 \times 10^{-3}$ & $4.5 \times 10^{-3}$ & $-4.9 \times 10^{0}$ & $4.8 \times 10^{-1}$ \\
\hline 00-25 & 35 & 35 & $2.8 \times 10^{-3}$ & $2.1 \times 10^{-2}$ & $5.8 \times 10^{-3}$ & $6.9 \times 10^{-3}$ & $3.7 \times 10^{-3}$ & $-5.1 \times 10^{0}$ & $4.5 \times 10^{-1}$ \\
\hline 00-40 & 34 & 34 & $2.0 \times 10^{-3}$ & $1.5 \times 10^{-2}$ & $4.9 \times 10^{-3}$ & $5.8 \times 10^{-3}$ & $2.7 \times 10^{-3}$ & $-5.3 \times 10^{0}$ & $4.5 \times 10^{-1}$ \\
\hline $00-60$ & 26 & 26 & $2.3 \times 10^{-3}$ & $1.5 \times 10^{-2}$ & $4.3 \times 10^{-3}$ & $5.1 \times 10^{-3}$ & $2.7 \times 10^{-3}$ & $-5.4 \times 10^{0}$ & $4.3 \times 10^{-1}$ \\
\hline
\end{tabular}

NOTE: Specific Activity is decay corrected to 1998.

a Number of individual samples or when integrated, number of complete profiles.

b Number of samples with minimum detection activities (MDA's) or when integrated, number of profiles that have one or more MDA's. 
Appendix A-4.10. Americium-241 radionuclide concentration summary for all soil profiles in 1994 on Aon Island (08I), Utirik Atoll.

\begin{tabular}{|c|c|c|c|c|c|c|c|c|c|}
\hline \multirow{2}{*}{$\begin{array}{l}\text { Soil } \\
\text { depth } \\
(\mathrm{cm})\end{array}$} & \multirow{2}{*}{\multicolumn{2}{|c|}{$N^{a} M^{\prime} A^{\prime} s^{b}$}} & \multicolumn{5}{|c|}{$\mathrm{Bq} \mathrm{g}^{-1}$ dry wt. } & \multirow{2}{*}{$\begin{array}{l}\text { Mean } \\
\text { of logs }\end{array}$} & \multirow{2}{*}{$\begin{array}{l}\text { SD } \\
\text { of logs }\end{array}$} \\
\hline & & & Minimum & Maximum & Median & Mean & SD & & \\
\hline 00-05 & 34 & 10 & $1.6 \times 10^{-3}$ & $5.0 \times 10^{-2}$ & $9.0 \times 10^{-3}$ & $1.3 \times 10^{-2}$ & $1.1 \times 10^{-2}$ & $-4.6 \times 10^{0}$ & $7.2 \times 10^{-1}$ \\
\hline 05-10 & 34 & 23 & $1.2 \times 10^{-3}$ & $2.4 \times 10^{-2}$ & $5.6 \times 10^{-3}$ & $6.6 \times 10^{-3}$ & $4.9 \times 10^{-3}$ & $-5.3 \times 10^{0}$ & $7.0 \times 10^{-1}$ \\
\hline 10-15 & 34 & 31 & $1.3 \times 10^{-3}$ & $4.0 \times 10^{-2}$ & $4.6 \times 10^{-3}$ & $6.3 \times 10^{-3}$ & $6.8 \times 10^{-3}$ & $-5.4 \times 10^{0}$ & $7.3 \times 10^{-1}$ \\
\hline $15-25$ & 34 & 33 & $6.7 \times 10^{-4}$ & $3.4 \times 10^{-2}$ & $2.5 \times 10^{-3}$ & $4.2 \times 10^{-3}$ & $5.9 \times 10^{-3}$ & $-5.8 \times 10^{0}$ & $7.6 \times 10^{-1}$ \\
\hline $25-40$ & 33 & 33 & $7.7 \times 10^{-4}$ & $1.4 \times 10^{-2}$ & $3.3 \times 10^{-3}$ & $3.7 \times 10^{-3}$ & $2.8 \times 10^{-3}$ & $-5.9 \times 10^{0}$ & $7.4 \times 10^{-1}$ \\
\hline $40-60$ & 27 & 27 & $1.0 \times 10^{-3}$ & $2.2 \times 10^{-2}$ & $2.1 \times 10^{-3}$ & $3.2 \times 10^{-3}$ & $4.0 \times 10^{-3}$ & $-6.0 \times 10^{0}$ & $6.4 \times 10^{-1}$ \\
\hline 00-05 & 34 & 10 & $1.6 \times 10^{-3}$ & $5.0 \times 10^{-2}$ & $9.0 \times 10^{-3}$ & $1.3 \times 10^{-2}$ & $1.1 \times 10^{-2}$ & $-4.6 \times 10^{0}$ & $7.2 \times 10^{-1}$ \\
\hline 00-10 & 34 & 25 & $3.0 \times 10^{-3}$ & $3.1 \times 10^{-2}$ & $7.3 \times 10^{-3}$ & $1.0 \times 10^{-2}$ & $6.7 \times 10^{-3}$ & $-4.8 \times 10^{0}$ & $5.6 \times 10^{-1}$ \\
\hline 00-15 & 34 & 33 & $3.1 \times 10^{-3}$ & $2.2 \times 10^{-2}$ & $7.3 \times 10^{-3}$ & $8.8 \times 10^{-3}$ & $4.6 \times 10^{-3}$ & $-4.9 \times 10^{0}$ & $4.8 \times 10^{-1}$ \\
\hline 00-25 & 34 & 34 & $2.8 \times 10^{-3}$ & $2.1 \times 10^{-2}$ & $5.8 \times 10^{-3}$ & $7.0 \times 10^{-3}$ & $3.7 \times 10^{-3}$ & $-5.1 \times 10^{0}$ & $4.5 \times 10^{-1}$ \\
\hline $00-40$ & 33 & 33 & $2.0 \times 10^{-3}$ & $1.5 \times 10^{-2}$ & $4.8 \times 10^{-3}$ & $5.8 \times 10^{-3}$ & $2.7 \times 10^{-3}$ & $-5.3 \times 10^{0}$ & $4.5 \times 10^{-1}$ \\
\hline 00-60 & 26 & 26 & $2.3 \times 10^{-3}$ & $1.5 \times 10^{-2}$ & $4.3 \times 10^{-3}$ & $5.1 \times 10^{-3}$ & $2.7 \times 10^{-3}$ & $-5.4 \times 10^{0}$ & $4.3 \times 10^{-1}$ \\
\hline
\end{tabular}

NOTE: Specific Activity is decay corrected to 1998.

a Number of individual samples or when integrated, number of complete profiles.

b Number of samples with minimum detection activities (MDA's) or when integrated, number of profiles that have one or more MDA's. 
Appendix A-4.11. Americium-241 radionuclide concentration summary for all soil profiles taken during the 1978 NMIRS on Aon Island (08I), Utirik Atoll.

\begin{tabular}{|c|c|c|c|c|c|c|c|c|c|}
\hline \multirow{2}{*}{$\begin{array}{l}\text { Soil } \\
\text { depth } \\
\text { (cm) }\end{array}$} & \multirow[b]{2}{*}{$\mathbf{N}^{\mathbf{a}}$} & \multirow[b]{2}{*}{ MDA's $^{b}$} & \multicolumn{5}{|c|}{ Bq $g^{-1}$ dry wt. } & \multirow{2}{*}{$\begin{array}{l}\text { Mean } \\
\text { of logs }\end{array}$} & \multirow{2}{*}{$\begin{array}{l}\text { SD } \\
\text { of logs }\end{array}$} \\
\hline & & & Minimum & Maximum & Median & Mean & SD & & \\
\hline 00-05 & 1 & 0 & $9.2 \times 10^{-3}$ & $9.2 \times 10^{-3}$ & $9.2 \times 10^{-3}$ & $9.2 \times 10^{-3}$ & $0.0 \times 10^{0}$ & $-4.7 \times 10^{0}$ & $0.0 \times 10^{0}$ \\
\hline 05-10 & 1 & 1 & $3.3 \times 10^{-3}$ & $3.3 \times 10^{-3}$ & $3.3 \times 10^{-3}$ & $3.3 \times 10^{-3}$ & $0.0 \times 10^{0}$ & $-5.7 \times 10^{0}$ & $0.0 \times 10^{0}$ \\
\hline $10-15$ & 1 & 1 & $3.7 \times 10^{-3}$ & $3.7 \times 10^{-3}$ & $3.7 \times 10^{-3}$ & $3.7 \times 10^{-3}$ & $0.0 \times 10^{0}$ & $-5.6 \times 10^{0}$ & $0.0 \times 10^{0}$ \\
\hline $15-25$ & 1 & 0 & $8.3 \times 10^{-3}$ & $8.3 \times 10^{-3}$ & $8.3 \times 10^{-3}$ & $8.3 \times 10^{-3}$ & $0.0 \times 10^{0}$ & $-4.8 \times 10^{0}$ & $0.0 \times 10^{0}$ \\
\hline $25-40$ & 1 & 0 & $5.0 \times 10^{-3}$ & $5.0 \times 10^{-3}$ & $5.0 \times 10^{-3}$ & $5.0 \times 10^{-3}$ & $0.0 \times 10^{0}$ & $-5.3 \times 10^{0}$ & $0.0 \times 10^{0}$ \\
\hline $40-60$ & 0 & 0 & $0.0 \times 10^{0}$ & $0.0 \times 10^{0}$ & $0.0 \times 10^{0}$ & $0.0 \times 10^{0}$ & $0.0 \times 10^{0}$ & $-0.0 \times 10^{0}$ & $0.0 \times 10^{0}$ \\
\hline 00-05 & 1 & 0 & $9.2 \times 10^{-3}$ & $9.2 \times 10^{-3}$ & $9.2 \times 10^{-3}$ & $9.2 \times 10^{-3}$ & $0.0 \times 10^{0}$ & $-4.7 \times 10^{0}$ & $0.0 \times 10^{0}$ \\
\hline 00-10 & 1 & 1 & $6.2 \times 10^{-3}$ & $6.2 \times 10^{-3}$ & $6.2 \times 10^{-3}$ & $6.2 \times 10^{-3}$ & $0.0 \times 10^{0}$ & $-5.1 \times 10^{0}$ & $0.0 \times 10^{0}$ \\
\hline 00-15 & 1 & 1 & $5.4 \times 10^{-3}$ & $5.4 \times 10^{-3}$ & $5.4 \times 10^{-3}$ & $5.4 \times 10^{-3}$ & $0.0 \times 10^{0}$ & $-5.2 \times 10^{0}$ & $0.0 \times 10^{0}$ \\
\hline 00-25 & 1 & 1 & $6.6 \times 10^{-3}$ & $6.6 \times 10^{-3}$ & $6.6 \times 10^{-3}$ & $6.6 \times 10^{-3}$ & $0.0 \times 10^{0}$ & $-5.0 \times 10^{0}$ & $0.0 \times 10^{0}$ \\
\hline 00-40 & 1 & 1 & $6.0 \times 10^{-3}$ & $6.0 \times 10^{-3}$ & $6.0 \times 10^{-3}$ & $6.0 \times 10^{-3}$ & $0.0 \times 10^{0}$ & $-5.1 \times 10^{0}$ & $0.0 \times 10^{0}$ \\
\hline $00-60$ & 0 & 0 & $0.0 \times 10^{0}$ & $0.0 \times 10^{0}$ & $0.0 \times 10^{0}$ & $0.0 \times 10^{0}$ & $0.0 \times 10^{0}$ & $-0.0 \times 10^{0}$ & $0.0 \times 10^{0}$ \\
\hline
\end{tabular}

NOTE: Specific Activity is decay corrected to 1998.

a Number of individual samples or when integrated, number of complete profiles.

b Number of samples with minimum detection activities (MDA's) or when integrated, number of profiles that have one or more MDA's. 
Appendix A-4.12. Americium-241 radionuclide concentration summary for all soil profiles taken in 1994 on Elluk Island (02I), Utirik Atoll.

\begin{tabular}{|c|c|c|c|c|c|c|c|c|c|}
\hline \multirow{2}{*}{$\begin{array}{l}\text { Soil } \\
\text { depth } \\
\text { (cm) }\end{array}$} & \multirow{2}{*}{\multicolumn{2}{|c|}{$\mathrm{N}^{\mathrm{a}} \mathrm{MDA}^{\prime} \mathbf{s}^{\mathrm{b}}$}} & \multicolumn{5}{|c|}{$\mathrm{Bq}^{-1}$ dry wt. } & \multirow{2}{*}{$\begin{array}{l}\text { Mean } \\
\text { of logs }\end{array}$} & \multirow{2}{*}{$\begin{array}{l}\text { SD } \\
\text { of logs }\end{array}$} \\
\hline & & & Minimum & Maximum & Median & Mean & SD & & \\
\hline 00-05 & 2 & 1 & $1.7 \times 10^{-2}$ & $7.6 \times 10^{-2}$ & $4.6 \times 10^{-2}$ & $4.6 \times 10^{-2}$ & $4.2 \times 10^{-2}$ & $-3.3 \times 10^{0}$ & $1.1 \times 10^{0}$ \\
\hline 05-10 & 2 & 1 & $2.9 \times 10^{-3}$ & $8.0 \times 10^{-3}$ & $5.5 \times 10^{-3}$ & $5.5 \times 10^{-3}$ & $3.6 \times 10^{-3}$ & $-5.3 \times 10^{0}$ & $7.2 \times 10^{-1}$ \\
\hline 10-15 & 2 & 2 & $1.9 \times 10^{-3}$ & $8.2 \times 10^{-3}$ & $5.0 \times 10^{-3}$ & $5.0 \times 10^{-3}$ & $4.4 \times 10^{-3}$ & $-5.5 \times 10^{0}$ & $1.0 \times 10^{0}$ \\
\hline $15-25$ & 2 & 2 & $1.3 \times 10^{-3}$ & $7.0 \times 10^{-2}$ & $3.6 \times 10^{-2}$ & $3.6 \times 10^{-2}$ & $4.8 \times 10^{-2}$ & $-4.6 \times 10^{0}$ & $2.8 \times 10^{0}$ \\
\hline $25-40$ & 2 & 2 & $1.5 \times 10^{-3}$ & $1.3 \times 10^{-2}$ & $7.4 \times 10^{-3}$ & $7.4 \times 10^{-3}$ & $8.4 \times 10^{-3}$ & $-5.4 \times 10^{0}$ & $1.6 \times 10^{0}$ \\
\hline $40-60$ & 0 & 0 & $0.0 \times 10^{0}$ & $0.0 \times 10^{0}$ & $0.0 \times 10^{0}$ & $0.0 \times 10^{0}$ & $0.0 \times 10^{0}$ & $-0.0 \times 10^{0}$ & $0.0 \times 10^{0}$ \\
\hline 00-05 & 2 & 1 & 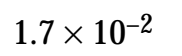 & -2 & -2 & $10^{-2}$ & $4.2 \times 10^{-2}$ & $\times 10^{0}$ & $\times 10^{0}$ \\
\hline 00-10 & 2 & 2 & $9.8 \times 10^{-3}$ & $4.2 \times 10^{-2}$ & $2.6 \times 10^{-2}$ & $2.6 \times 10^{-2}$ & $2.3 \times 10^{-2}$ & $-3.9 \times 10^{0}$ & $1.0 \times 10^{0}$ \\
\hline 00-15 & 2 & 2 & $7.2 \times 10^{-3}$ & $3.1 \times 10^{-2}$ & $1.9 \times 10^{-2}$ & $1.9 \times 10^{-2}$ & $1.7 \times 10^{-2}$ & $-4.2 \times 10^{0}$ & $1.0 \times 10^{0}$ \\
\hline $00-25$ & 2 & 2 & $4.9 \times 10^{-3}$ & $4.6 \times 10^{-2}$ & $2.6 \times 10^{-2}$ & $2.6 \times 10^{-2}$ & $2.9 \times 10^{-2}$ & $-4.2 \times 10^{0}$ & $1.6 \times 10^{0}$ \\
\hline 00-40 & 2 & 2 & $3.6 \times 10^{-3}$ & $3.4 \times 10^{-2}$ & $1.9 \times 10^{-2}$ & $1.9 \times 10^{-2}$ & $2.1 \times 10^{-2}$ & $-4.5 \times 10^{0}$ & $1.6 \times 10^{0}$ \\
\hline $00-60$ & 0 & 0 & $0.0 \times 10^{0}$ & $0.0 \times 10^{0}$ & $0.0 \times 10^{0}$ & $0.0 \times 10^{0}$ & $0.0 \times 10^{0}$ & $-0.0 \times 10^{0}$ & $0.0 \times 10^{0}$ \\
\hline
\end{tabular}

NOTE: Specific Activity is decay corrected to 1998.

a Number of individual samples or when integrated, number of complete profiles.

b Number of samples with minimum detection activities (MDA's) or when integrated, number of profiles that have one or more MDA's. 


\section{Appendix B}

Detailed Footnotes and References for Table 6 on the Radionuclide Concentrations in

Terrestrial and Marine Foods, Birds, Animals, Water, and Surface Soil, Utirik Atoll 
Appendix B-1. Cesium-137 footnotes and references.

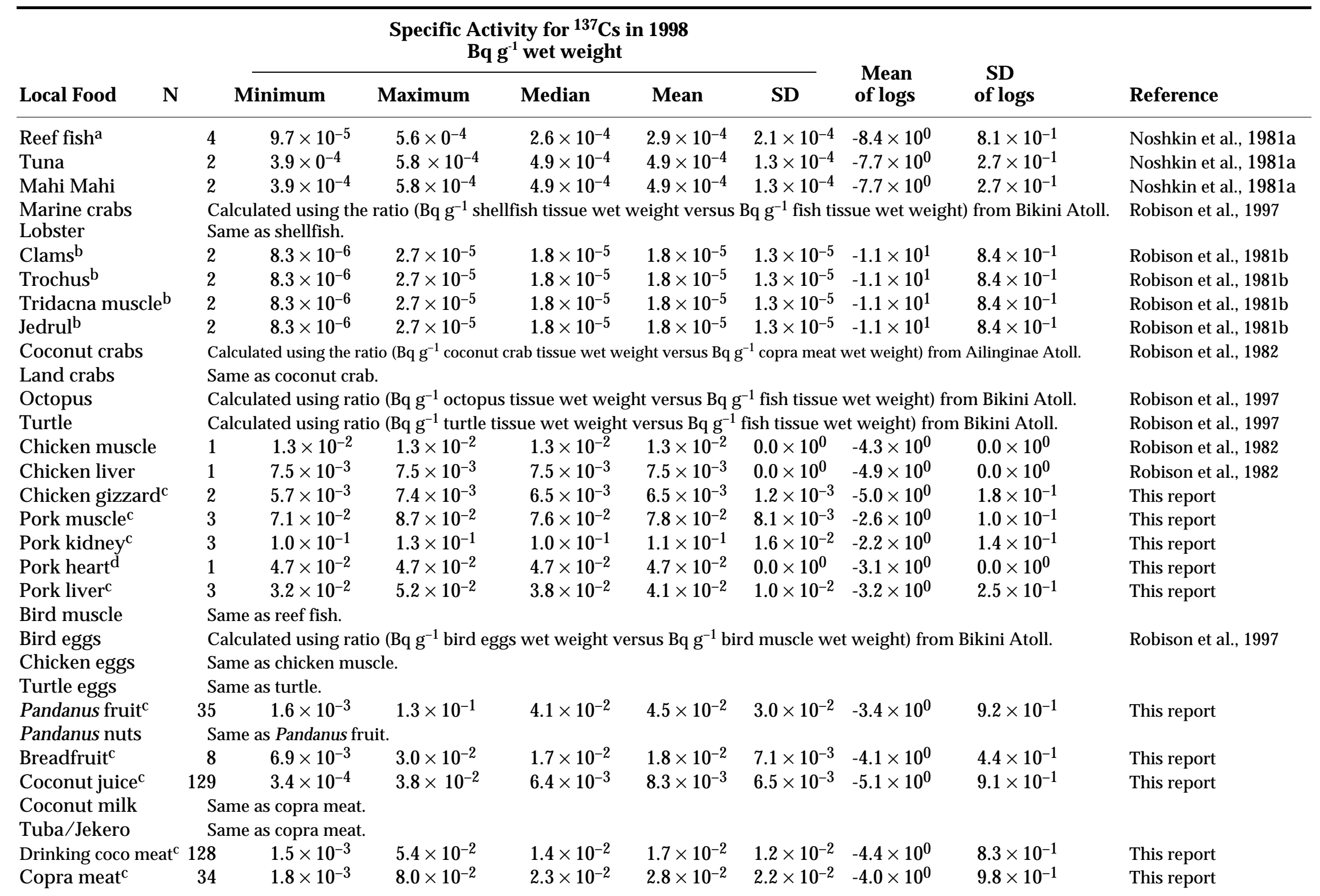


Appendix B-1. Continued.

\begin{tabular}{|c|c|c|c|c|c|c|c|c|c|}
\hline \multirow[b]{2}{*}{ Local Food } & \multirow[b]{2}{*}{$\mathbf{N}$} & \multicolumn{5}{|c|}{$\begin{array}{l}\text { Specific Activity for }{ }^{137} \text { Cs in } 1998 \\
\text { Bq g }^{-1} \text { wet weight }\end{array}$} & \multirow{2}{*}{$\begin{array}{l}\text { Mean } \\
\text { of logs }\end{array}$} & \multirow{2}{*}{$\begin{array}{l}\text { SD } \\
\text { of logs }\end{array}$} & \multirow[b]{2}{*}{ Reference } \\
\hline & & Minimum & Maximum & Median & Mean & SD & & & \\
\hline Sprout. coconut & \multicolumn{9}{|c|}{ Same as copra meat. } \\
\hline Marsh. cake & \multicolumn{9}{|c|}{ Same as copra meat. } \\
\hline Papayac & 2 & $2.3 \times 10^{-2}$ & $8.4 \times 10^{-2}$ & $5.4 \times 10^{-2}$ & $5.4 \times 10^{-2}$ & $4.4 \times 10^{-2}$ & $-3.1 \times 10^{0}$ & $9.3 \times 10^{-1}$ & This report \\
\hline Squash & \multicolumn{8}{|c|}{ Calculated using concentration ratio (Bq g ${ }^{-1}$ fruit wet weight versus $\mathrm{Bq} \mathrm{g}^{-1}$ soil dry weight) from Bikini Atoll. } & Robison and Conrado, 19 \\
\hline Pumpkin & \multicolumn{8}{|c|}{ Same as squash. } & \\
\hline Banana $^{c}$ & 2 & $1.4 \times 10^{-3}$ & $1.3 \times 10^{-2}$ & $7.3 \times 10^{-3}$ & $7.3 \times 10^{-3}$ & $8.3 \times 10^{-3}$ & $-5.4 \times 10^{0}$ & $1.6 \times 10^{0}$ & This report \\
\hline Arrowroot ${ }^{\mathrm{d}}$ & \multicolumn{8}{|c|}{ Data used is from Aon Island on Utirik Atoll. } & This report \\
\hline Citrus & \multicolumn{8}{|c|}{ Same as breadfruit. } & \\
\hline Rainwater & 1 & $3.3 \times 10^{-6}$ & $3.3 \times 10^{-6}$ & $3.3 \times 10^{-6}$ & $3.3 \times 10^{-6}$ & $0.0 \times 10^{0}$ & $-1.3 \times 10^{1}$ & $0.0 \times 10^{0}$ & Noshkin et al., 1981b \\
\hline Wellwater ${ }^{\mathrm{c}}$ & 5 & $2.8 \times 10^{-5}$ & $1.6 \times 10^{-4}$ & $4.3 \times 10^{-5}$ & $6.7 \times 10^{-5}$ & $5.3 \times 10^{-5}$ & $-9.8 \times 10^{0}$ & $7.1 \times 10^{-1}$ & This report \\
\hline Malolo & \multicolumn{8}{|c|}{ Same as rainwater. } & \multirow{6}{*}{ This report } \\
\hline Coffee/Tea & \multicolumn{8}{|c|}{ Same as rainwater. } & \\
\hline Soil ${ }^{\mathrm{d}}$ & \multicolumn{8}{|c|}{ Calculated using time distributions of $19 \mathrm{~h} \mathrm{~d}^{-1}$ in village area, $3 \mathrm{~h} \mathrm{~d}^{-1}$ in interior area and $2 \mathrm{~h} \mathrm{~d}^{-1}$ on the beach. } & \\
\hline Village $(0-5 \mathrm{~cm})$ & 17 & $1.3 \times 10^{-3}$ & $1.3 \times 10^{-1}$ & $2.2 \times 10^{-2}$ & $3.6 \times 10^{-2}$ & $3.6 \times 10^{-2}$ & $-4.0 \times 10^{0}$ & $1.4 \times 10^{0}$ & \\
\hline Interior $(0-5 \mathrm{~cm})$ & 128 & $7.2 \times 10^{-4}$ & $2.9 \times 10^{-1}$ & $6.0 \times 10^{-2}$ & $6.8 \times 10^{-2}$ & $5.0 \times 10^{-2}$ & $-3.0 \times 10^{0}$ & $9.2 \times 10^{-1}$ & \\
\hline $\operatorname{Beach}(0-5 \mathrm{~cm})$ & 2 & $3.6 \times 10^{-4}$ & $6.4 \times 10^{-4}$ & $5.0 \times 10^{-4}$ & $5.0 \times 10^{-4}$ & $2.0 \times 10^{-4}$ & $-7.7 \times 10^{0}$ & $4.0 \times 10^{-1}$ & \\
\hline
\end{tabular}

a Number of pooled samples from the same catch and species. Number of individual fish samples is 109.

b Data used from Tridacna crocea and Hippopus hippopus.

c Specific activity is based on determinations from samples taken from Utirik Island during the 1978 NMIRS and in 1993.

d Specific activity is based on determinations from samples taken from Utirik Island in 1993.

NOTE: $\mathrm{N}=$ the number of composite samples. 
Appendix B-2. Strontium-90 footnotes and references.

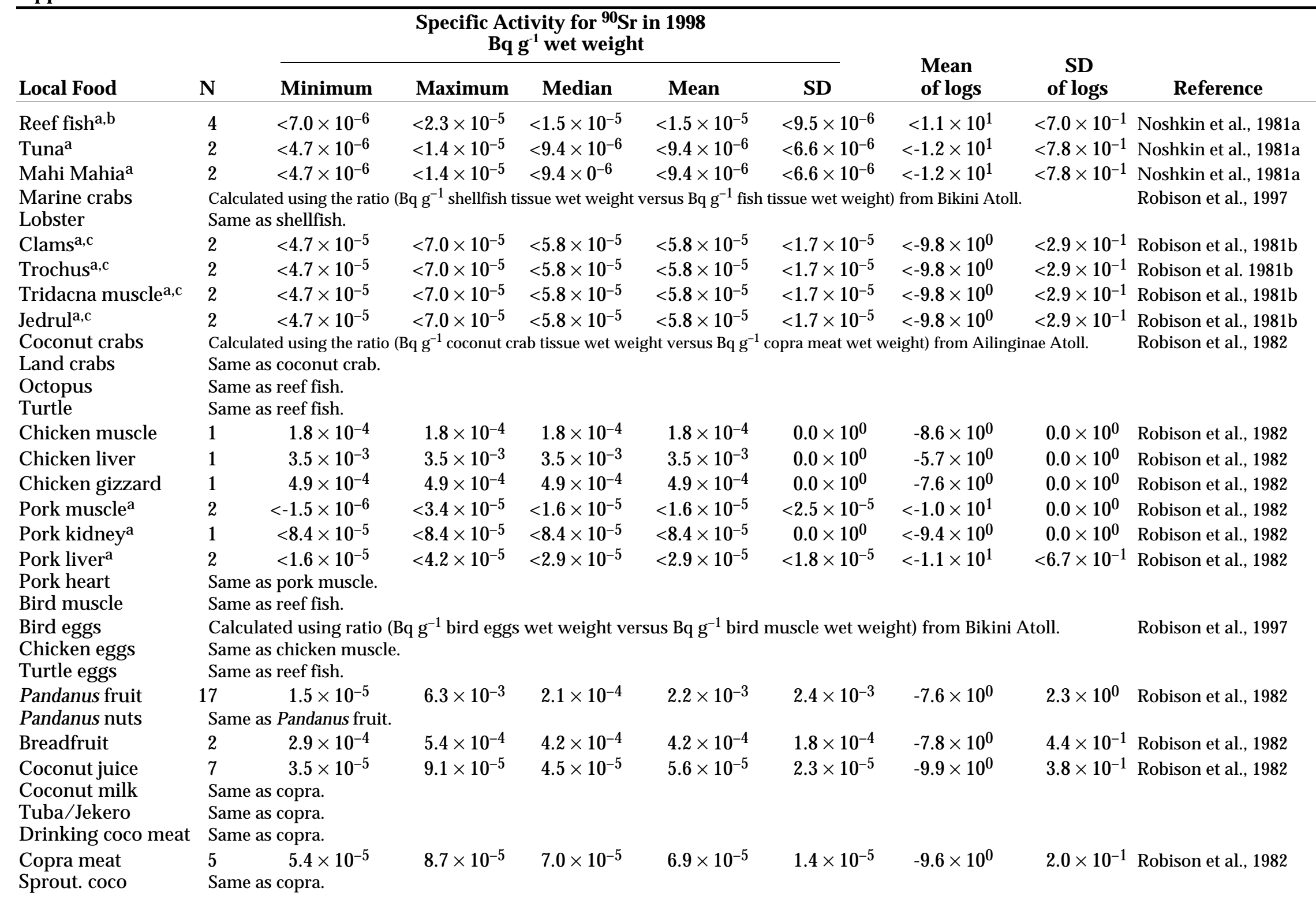


Appendix B-2. Continued.

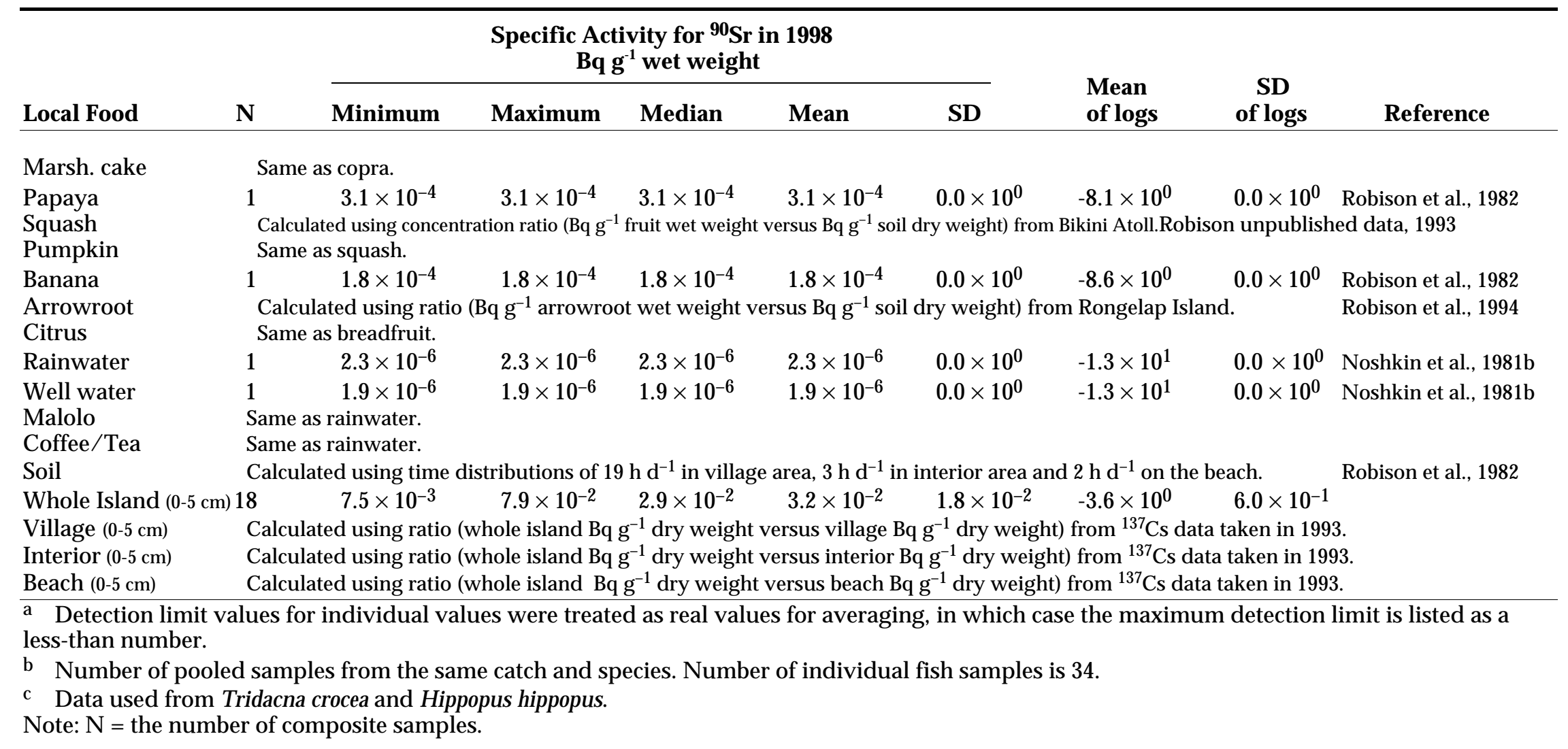


Appendix B-3. Plutonium-239+240 footnotes and references.

\begin{tabular}{|c|c|c|c|c|c|c|c|c|c|c|}
\hline \multirow[b]{2}{*}{ Local Food } & \multirow[b]{2}{*}{$\mathbf{N}^{\mathbf{a}}$} & \multirow[b]{2}{*}{$\mathbf{N}^{b}$} & \multicolumn{5}{|c|}{$\begin{array}{l}\text { Specific Activity for }{ }^{239+240} \mathrm{Pu} \text { in } 1998 \\
\text { Bq g-1 wet weight }\end{array}$} & \multirow{2}{*}{$\begin{array}{l}\text { Mean } \\
\text { of logs }\end{array}$} & \multirow{2}{*}{$\begin{array}{c}\text { SD } \\
\text { of logs }\end{array}$} & \multirow[b]{2}{*}{ Reference } \\
\hline & & & Minimum & Maximum & Median & Mean & SD & & & \\
\hline Reef fish $^{c}$ & 3 & 2 & $1.9 \times 10^{-7}$ & $1.5 \times 10^{-5}$ & $7.4 \times 10^{-7}$ & $3.7 \times 10^{-6}$ & $6.3 \times 10^{-6}$ & $-1.4 \times 10^{1}$ & $1.7 \times 10^{0}$ & Noshkin et al., 1981a \\
\hline Tuna & 2 & - & $<3.7 \times 10^{-8}$ & $<3.7 \times 10^{-7}$ & $<2.0 \times 10^{-7}$ & $<2.0 \times 10^{-7}$ & $<2.4 \times 10^{-7}$ & $<-1.6 \times 10^{1}$ & $<1.6 \times 10^{0}$ & Noshkin et al., 1981a \\
\hline Mahi Mahi & 2 & - & $<3.7 \times 10^{-8}$ & $<3.7 \times 10^{-7}$ & $<2.0 \times 10^{-7}$ & $<2.0 \times 10^{-7}$ & $<2.4 \times 10^{-7}$ & $<-1.6 \times 10^{1}$ & $<1.6 \times 10^{0}$ & Noshkin et al., 1981a \\
\hline $\begin{array}{l}\text { Marine crabs } \\
\text { Lobster }\end{array}$ & \multicolumn{9}{|c|}{$\begin{array}{l}\text { Calculated using the ratio ( } \mathrm{Bq} \mathrm{g}^{-1} \text { shellfish tissue wet weight versus } \mathrm{Bq}^{-1} \text { fish tissue wet weight) from Bikini Atoll. } \\
\text { Same as shellfish. }\end{array}$} & Robison et al., 1997 \\
\hline Clams $^{\mathrm{d}}$ & - & 2 & $4.1 \times 10^{-6}$ & $2.9 \times 10^{-5}$ & $1.6 \times 10^{-5}$ & $1.6 \times 10^{-5}$ & $1.7 \times 10^{-5}$ & $-1.1 \times 10^{1}$ & $1.4 \times 10^{0}$ & Noshkin et al., 1981a \\
\hline Trochus $^{d}$ & - & 2 & $4.1 \times 10^{-6}$ & $2.9 \times 10^{-5}$ & $1.6 \times 10^{-5}$ & $1.6 \times 10^{-5}$ & $1.7 \times 10^{-5}$ & $-1.1 \times 10^{1}$ & $1.4 \times 10^{0}$ & Noshkin et al., 1981a \\
\hline Tridacna muscle ${ }^{\mathrm{d}}$ & - & 2 & $4.1 \times 10^{-6}$ & $2.9 \times 10^{-5}$ & $1.6 \times 10^{-5}$ & $1.6 \times 10^{-5}$ & $1.7 \times 10^{-5}$ & $-1.1 \times 10^{1}$ & $1.4 \times 10^{0}$ & Noshkin et al., 1981a \\
\hline Jedruld & - & 2 & $4.1 \times 10^{-6}$ & $2.9 \times 10^{-5}$ & $1.6 \times 10^{-5}$ & $1.6 \times 10^{-5}$ & $1.7 \times 10^{-5}$ & $-1.1 \times 10^{1}$ & $1.4 \times 10^{0}$ & Noshkin et al., 1981a \\
\hline $\begin{array}{l}\text { Coconut crabs } \\
\text { Land crabs } \\
\text { Octopus } \\
\text { Turtle }\end{array}$ & \multicolumn{9}{|c|}{ Calculated using the ratio ( $\mathrm{Bq} \mathrm{g}^{-1}$ coconut crab tissue wet wt. versus $\mathrm{Bq}^{-1}$ copra meat wet wt.) from Ailinginae Atoll. } & Robison et al., 1982 \\
\hline Chicken muscle & - & 1 & $9.5 \times 10^{-7}$ & $9.5 \times 10^{-7}$ & $9.5 \times 10^{-7}$ & $9.5 \times 10^{-7}$ & $0.0 \times 10^{0}$ & $-1.4 \times 10^{1}$ & $0.0 \times 10^{0}$ & Robison et al., 1982 \\
\hline Chicken liver & \multicolumn{10}{|c|}{ Same as chicken muscle. } \\
\hline Chicken gizzard & - & 1 & $1.1 \times 10^{-5}$ & $1.1 \times 10^{-5}$ & $1.1 \times 10^{-5}$ & $1.1 \times 10^{-5}$ & $0.0 \times 10^{0}$ & $-1.1 \times 10^{1}$ & $0.0 \times 10^{0}$ & Robison et al., 1982 \\
\hline Pork muscle & 2 & - & $<1.5 \times 10^{-7}$ & $<6.4 \times 10^{-7}$ & $<4.0 \times 10^{-7}$ & $<4.0 \times 10^{-7}$ & $<3.5 \times 10^{-7}$ & $<-1.5 \times 10^{1}$ & $<1.0 \times 10^{0}$ & Robison et al., 1982 \\
\hline Pork kidney & 1 & - & $<1.7 \times 10^{-5}$ & $<1.7 \times 10^{-5}$ & $<1.7 \times 10^{-5}$ & $<1.7 \times 10^{-5}$ & $0.0 \times 10^{0}$ & $<-1.1 \times 10^{1}$ & $0.0 \times 10^{0}$ & Robison et al., 1982 \\
\hline Pork liver & - & 2 & $3.3 \times 10^{-6}$ & $7.9 \times 10^{-6}$ & $5.6 \times 10^{-6}$ & $5.6 \times 10^{-6}$ & $3.3 \times 10^{-6}$ & $-1.2 \times 10^{1}$ & $6.2 \times 10^{-1}$ & Robison et al., 1982 \\
\hline Pork heart & \multicolumn{10}{|c|}{ Same as pork muscle. } \\
\hline Bird muscle & \multicolumn{10}{|c|}{ Same as reef fish. } \\
\hline Bird eggs & \multicolumn{10}{|c|}{ Same as reef fish. } \\
\hline Chicken eggs & \multicolumn{10}{|c|}{ Same chicken muscle. } \\
\hline Turtle eggs & \multicolumn{10}{|c|}{ Same as reef fish. } \\
\hline Pandanus fruit & - & 15 & $2.0 \times 10^{-7}$ & $8.6 \times 10^{-6}$ & $7.0 \times 10^{-7}$ & $2.1 \times 10^{-6}$ & $2.9 \times 10^{-6}$ & $-1.4 \times 10^{1}$ & $1.2 \times 10^{0}$ & Robison et al., 1982 \\
\hline Pandanus nuts & \multicolumn{10}{|c|}{ Same as Pandanus fruit. } \\
\hline Breadfruit & - & 2 & $3.0 \times 10^{-7}$ & $8.0 \times 10^{-7}$ & $5.5 \times 10^{-7}$ & $5.5 \times 10^{-7}$ & $3.5 \times 10^{-7}$ & $-1.5 \times 10^{1}$ & $7.0 \times 10^{-1}$ & Robison et al., 1982 \\
\hline Coconut juice & 4 & 3 & $-6.9 \times 0^{-7}$ & $3.3 \times 0^{-6}$ & $7.6 \times 0^{-7}$ & $9.5 \times 10-7$ & $1.4 \times 10^{-6}$ & $-1.4 \times 10^{1}$ & $8.7 \times 0^{-1}$ & Robison et al., 1982 \\
\hline Coconut milk & \multicolumn{10}{|c|}{ Same as copra. } \\
\hline Tuba/Jekero & \multicolumn{10}{|c|}{ Same as copra. } \\
\hline Drinking coco meat & \multicolumn{10}{|c|}{ Same as copra. } \\
\hline Copra meat & 4 & 5 & $-3.7 \times 0^{-6}$ & $7.9 \times 0^{-6}$ & $2.6 \times 0^{-6}$ & $2.2 \times 0^{-6}$ & $3.9 \times 0^{-6}$ & $-1.3 \times 0^{1}$ & $7.6 \times 0^{-1}$ & Robison et al., 1982 \\
\hline Sprout. coco & \multicolumn{10}{|c|}{ Same as copra. } \\
\hline
\end{tabular}


Appendix B-3. Continued.

\begin{tabular}{|c|c|c|c|c|c|c|c|c|c|c|}
\hline \multirow[b]{2}{*}{ Local Food } & \multirow[b]{2}{*}{$\mathbf{N}^{\mathbf{a}}$} & \multirow[b]{2}{*}{$\mathbf{N}^{\mathbf{b}}$} & \multicolumn{4}{|c|}{$\begin{array}{c}\text { Specific Activity for }{ }^{239+240} \mathrm{Pu} \text { in } 1998 \\
\mathrm{~Bq} \mathrm{~g}^{-1} \text { wet weight }\end{array}$} & \multirow[b]{2}{*}{ SD } & \multirow{2}{*}{$\begin{array}{l}\text { Mean } \\
\text { of logs }\end{array}$} & \multirow{2}{*}{$\begin{array}{l}\text { SD } \\
\text { of logs }\end{array}$} & \multirow[b]{2}{*}{ Reference } \\
\hline & & & Minimum & Maximum & Median & Mean & & & & \\
\hline Marsh. cake & \multicolumn{10}{|c|}{ Same as copra. } \\
\hline Papaya & 1 & - & $<2.3 \times 0^{-7}$ & $<2.3 \times 0^{-7}$ & $<2.3 \times 0^{-7}$ & $<2.3 \times 0^{-7}$ & $0.0 \times 0^{0}$ & $-1.5 \times 0^{1}$ & $0.0 \times 0^{0}$ & This report \\
\hline $\begin{array}{l}\text { Squash } \\
\text { Pumpkin }\end{array}$ & \multicolumn{8}{|c|}{$\begin{array}{l}\text { Calculated using concentration ratio }\left(\mathrm{Bq} \mathrm{g}^{-1} \text { fruit wet weight versus } \mathrm{Bq}^{-1} \text { soil dry weight) from Bikini Atoll. }\right. \\
\text { Same as squash. }\end{array}$} & \multicolumn{2}{|c|}{ Robison unpublished data, 1993} \\
\hline Banana & - & 1 & $5.2 \times 10^{-7}$ & $5.2 \times 10^{-7}$ & $5.2 \times 10^{-7}$ & $5.2 \times 10^{-7}$ & $0.0 \times 10^{0}$ & $-1.5 \times 10^{1}$ & $0.0 \times 10^{0}$ & Robison et al., 1982 \\
\hline $\begin{array}{l}\text { Arrowroot } \\
\text { Citrus }\end{array}$ & \multicolumn{9}{|c|}{$\begin{array}{l}\text { Calculated using ratio ( } \mathrm{Bq} \mathrm{g}^{-1} \text { arrowroot wet weight versus } \mathrm{Bq}^{-1} \text { soil dry weight) from Rongelap Island } \\
\text { Same as breadfruit. }\end{array}$} & Robison et al., 1994 \\
\hline Rainwater & - & 1 & $1.9 \times 10^{-8}$ & $1.9 \times 10^{-8}$ & $1.9 \times 10^{-8}$ & $1.9 \times 10^{-8}$ & $0.0 \times 10^{0}$ & $-1.8 \times 10^{1}$ & $0.0 \times 10^{0}$ & Noshkin et al., 1981b \\
\hline Well water & - & 1 & $7.4 \times 10^{-9}$ & $7.4 \times 10^{-9}$ & $7.4 \times 10^{-9}$ & $7.4 \times 10^{-9}$ & $0.0 \times 10^{0}$ & $-1.9 \times 10^{1}$ & $0.0 \times 10^{0}$ & Noshkin et al., 1981b \\
\hline Malolo & \multicolumn{10}{|c|}{ Same as rainwater. } \\
\hline Coffee/tea & \multicolumn{10}{|c|}{ Same as rainwater. } \\
\hline Soil & \multicolumn{10}{|c|}{ Calculated using time distributions of $19 \mathrm{~h} \mathrm{~d}^{-1}$ in village area, $3 \mathrm{~h} \mathrm{~d}^{-1}$ in interior area and $2 \mathrm{~h} \mathrm{~d}^{-1}$ on the beach. } \\
\hline Whole island $(0-5 \mathrm{~cm})$ & 28 & - & $2.7 \times 10^{-4}$ & $4.4 \times 10^{-2}$ & $1.5 \times 10^{-2}$ & $1.7 \times 10^{-2}$ & $1.1 \times 10^{-2}$ & $-4.4 \times 10^{0}$ & $9.9 \times 10^{-1}$ & 1 Robison et al., 1982 \\
\hline Village $(0-5 \mathrm{~cm})$ & \multirow{3}{*}{\multicolumn{10}{|c|}{$\begin{array}{l}\text { Calculated using ratio (whole island } \mathrm{Bq} \mathrm{g}^{-1} \text { dry weight versus village } \mathrm{Bq} \mathrm{g}^{-1} \text { dry weight) from }{ }^{137} \mathrm{Cs} \text { data taken in } 1993 . \\
\text { Calculated using ratio (whole island } \mathrm{Bq} \mathrm{g}^{-1} \text { dry weight versus interior Bq g g dry weight) from }{ }^{137} \mathrm{Cs} \text { data taken in } 1993 . \\
\text { Calculated using ratio (whole island } \mathrm{Bq} \mathrm{g}{ }^{-1} \text { dry weight versus beach Bq g }{ }^{-1} \text { dry weight) from }{ }^{137}{ }^{C} \text { s data taken in } 1993 .\end{array}$}} \\
\hline Interior $(0-5 \mathrm{~cm})$ & & & & & & & & & & \\
\hline Beach $(0-5 \mathrm{~cm})$ & & & & & & & & & & \\
\hline
\end{tabular}


Appendix B-4. Americium-241 footnotes and references.

\begin{tabular}{|c|c|c|c|c|c|c|c|c|c|c|}
\hline \multirow[b]{2}{*}{ Local Food } & \multirow[b]{2}{*}{$\mathbf{N}^{\mathbf{a}}$} & \multirow[b]{2}{*}{$\mathbf{N}^{\mathbf{b}}$} & \multicolumn{5}{|c|}{$\begin{array}{c}\text { Specific Activity for }{ }^{241} \text { Am in } 1998 \\
\text { Bq g }^{-1} \text { wet weight }\end{array}$} & \multirow{2}{*}{$\begin{array}{l}\text { Mean } \\
\text { of logs }\end{array}$} & \multirow{2}{*}{$\begin{array}{l}\text { SD } \\
\text { of logs }\end{array}$} & \multirow[b]{2}{*}{ Reference } \\
\hline & & & Minimum & Maximum & Median & Mean & SD & & & \\
\hline Reef fishc,d & 4 & 1 & $<3.7 \times 10^{-8}$ & $<2.2 \times 10^{-5}$ & $<3.7 \times 10^{-7}$ & $<4.8 \times 10^{-6}$ & $<9.8 \times 10^{-6}$ & $<-1.4 \times 10^{1}$ & $<2.3 \times 10^{0}$ & Noshkin et al., 1981a \\
\hline Tuna & \multicolumn{9}{|c|}{ Calculated using the ratio (Bq g ${ }^{-1}$ reef fish tissue wet weight versus $\mathrm{Bq} \mathrm{g}^{-1}$ pelagic fish tissue wet weight) from Bikini Atoll. } & Robison et al., 1997 \\
\hline Mahi Mahi & \multicolumn{9}{|c|}{ Calculated using the ratio ( $\mathrm{Bq} \mathrm{g}^{-1}$ reef fish tissue wet weight versus $\mathrm{Bq} \mathrm{g}^{-1}$ pelagic fish tissue wet weight) from Bikini Atoll. } & Robison et al., 1997 \\
\hline Marine crabs & \multicolumn{9}{|c|}{ Calculated using the ratio (Bq g ${ }^{-1}$ shellfish tissue wet weight versus $\mathrm{Bq} \mathrm{g}^{-1}$ fish tissue wet weight) from Bikini Atoll. } & Robison et al., 1997 \\
\hline Lobster & \multicolumn{10}{|c|}{ Same as shellfish. } \\
\hline Clams $\mathrm{e}^{\mathrm{i}}$ & 2 & - & $<1.7 \times 10^{-6}$ & $<6.1 \times 10^{-6}$ & $<3.9 \times 10^{-6}$ & $<3.9 \times 10^{-6}$ & $<3.1 \times 10^{-6}$ & $<-1.3 \times 10^{1}$ & $<9.2 \times 10^{-1}$ & Noshkin et al., 1981b \\
\hline Trochuse & 2 & - & $<1.7 \times 10^{-6}$ & $<6.1 \times 10^{-6}$ & $<3.9 \times 10^{-6}$ & $<3.9 \times 10^{-6}$ & $<3.1 \times 10^{-6}$ & $<-1.3 \times 10^{1}$ & $<9.2 \times 10^{-1}$ & Noshkin et al., 1981b \\
\hline Tridacna muscle $\mathrm{e}^{\mathrm{e}}$ & 2 & - & $<1.7 \times 10^{-6}$ & $<6.1 \times 10^{-6}$ & $<3.9 \times 10^{-6}$ & $<3.9 \times 10^{-6}$ & $<3.1 \times 10^{-6}$ & $<-1.3 \times 10^{1}$ & $<9.2 \times 10^{-1}$ & Noshkin et al., 1981b \\
\hline Jedrule & 2 & - & $<1.7 \times 10^{-6}$ & $<6.1 \times 10^{-6}$ & $<3.9 \times 10^{-6}$ & $<3.9 \times 10^{-6}$ & $<3.1 \times 10^{-6}$ & $<-1.3 \times 10^{1}$ & $<9.2 \times 10^{-1}$ & Noshkin et al., 1981b \\
\hline Coconut crabs & \multicolumn{9}{|c|}{ Calculated using the ratio ( $\mathrm{Bq} \mathrm{g}^{-1}$ coconut crab tissue wet weight versus $\mathrm{Bq} \mathrm{g}^{-1}$ copra meat wet weight) from Ailinginae Atoll. } & Robison et al., 1982 \\
\hline Land crabs & \multicolumn{9}{|c|}{ Same as coconut crab. } & \\
\hline Octopus & \multicolumn{9}{|c|}{ Same as reef fish. } & \\
\hline Turtle & \multicolumn{10}{|c|}{ Same as reef fish. } \\
\hline Chicken muscle & - & 1 & $1.9 \times 10^{-6}$ & $1.9 \times 10^{-6}$ & $1.9 \times 10^{-6}$ & $1.9 \times 10^{-6}$ & $0.0 \times 10^{0}$ & $-1.3 \times 10^{1}$ & $0.0 \times 10^{0}$ & Robison et al., 1982 \\
\hline Chicken liver & - & 1 & $1.1 \times 10^{-5}$ & $1.1 \times 10^{-5}$ & $1.1 \times 10^{-5}$ & $1.1 \times 10^{-5}$ & $0.0 \times 10^{0}$ & $-1.1 \times 10^{1}$ & $0.0 \times 10^{0}$ & Robison et al., 1982 \\
\hline Chicken gizzard & - & 1 & $9.8 \times 10^{-6}$ & $9.8 \times 10^{-6}$ & $9.8 \times 10^{-6}$ & $9.8 \times 10^{-6}$ & $0.0 \times 10^{0}$ & $-1.2 \times 10^{1}$ & $0.0 \times 10^{0}$ & Robison et al., 1982 \\
\hline Pork muscle & 2 & - & $<5.4 \times 10^{-7}$ & $<7.0 \times 10^{-7}$ & $<6.2 \times 10^{-7}$ & $<6.2 \times 10^{-7}$ & $<1.1 \times 10^{-7}$ & $<-1.4 \times 10^{1}$ & $<1.8 \times 10^{-1}$ & Robison et al., 1982 \\
\hline Pork kidney & 1 & - & $<5.0 \times 10^{-6}$ & $<5.0 \times 10^{-6}$ & $<5.0 \times 10^{-6}$ & $<5.0 \times 10^{-6}$ & $0.0 \times 10^{0}$ & $<-1.2 \times 10^{1}$ & $0.0 \times 10^{0}$ & Robison et al., 1982 \\
\hline Pork liver & - & 2 & $1.1 \times 10^{-6}$ & $5.1 \times 10^{-6}$ & $3.1 \times 10^{-6}$ & $3.1 \times 10^{-6}$ & $2.8 \times 10^{-6}$ & $-1.3 \times 10^{1}$ & $1.1 \times 10^{0}$ & Robison et al., 1982 \\
\hline Pork heart & \multicolumn{10}{|c|}{ Same as pork muscle. } \\
\hline Bird muscle & \multicolumn{10}{|c|}{ Same as reef fish. } \\
\hline Bird eggs & \multicolumn{10}{|c|}{ Same as reef Fish. } \\
\hline Chicken eggs & \multicolumn{10}{|c|}{ Same as chicken muscle. } \\
\hline Turtle eggs & \multicolumn{10}{|c|}{ Same as reef fish. } \\
\hline Pandanus fruit & 4 & 9 & $3.9 \times 10^{-7}$ & $1.6 \times 10^{-5}$ & $1.7 \times 10^{-6}$ & $3.2 \times 10^{-6}$ & $4.1 \times 10^{-6}$ & $-1.3 \times 10^{1}$ & $1.1 \times 10^{0}$ & Robison et al., 1982 \\
\hline Pandanus nuts & \multicolumn{10}{|c|}{ Same as Pandanus fruit. } \\
\hline Breadfruit & - & 1 & $7.3 \times 10^{-7}$ & $7.3 \times 10^{-7}$ & $7.3 \times 10^{-7}$ & $7.3 \times 10^{-7}$ & $0.0 \times 10^{0}$ & $-1.4 \times 10^{1}$ & $0.0 \times 10^{0}$ & Robison et al., 1982 \\
\hline Coconut juice & 2 & 5 & $-1.6 \times 10^{-6}$ & $5.4 \times 10^{-6}$ & $2.4 \times 10^{-6}$ & $2.3 \times 10^{-6}$ & $2.5 \times 10^{-6}$ & $-1.3 \times 10^{1}$ & $-8.6 \times 10^{-1}$ & Robison et al., 1982 \\
\hline Coconut milk & \multicolumn{10}{|c|}{ Same as copra. } \\
\hline Tuba/Jekero & \multicolumn{10}{|c|}{ Same as copra. } \\
\hline
\end{tabular}


Appendix B-4. Continued.

\begin{tabular}{|c|c|c|c|c|c|c|c|c|c|}
\hline \multirow[b]{2}{*}{ Local Food } & \multirow[b]{2}{*}{$\mathbf{N}^{\mathbf{a}}$} & \multirow[b]{2}{*}{$\mathbf{N}^{\mathbf{b}}$} & \multicolumn{4}{|c|}{$\begin{array}{c}\text { Specific Activity for }{ }^{241} \mathrm{Am} \text { in } 1998 \\
\mathrm{~Bq} \mathrm{~g}^{-1} \text { wet weight }\end{array}$} & SD & \multirow{2}{*}{$\begin{array}{l}\text { SD } \\
\text { of logs }\end{array}$} & \multirow[b]{2}{*}{ Reference } \\
\hline & & & Minimum & Maximum & Median & Mean & $\begin{array}{l}\text { Mean } \\
\text { of logs }\end{array}$ & & \\
\hline \multicolumn{10}{|c|}{ Drinking coco meat Same as copra. } \\
\hline $\begin{array}{l}\text { Copra Meat } \\
\text { Sprout. coco } \\
\text { Marsh. Cake }\end{array}$ & \multicolumn{8}{|c|}{$\begin{array}{l}\text { Calculated usin } \\
\text { Same as copra. } \\
\text { Same as copra. }\end{array}$} & Robison et al., 1982 \\
\hline Papaya & - & 1 & $8.9 \times 10^{-7}$ & $8.9 \times 10^{-7}$ & $8.9 \times 10^{-7}$ & $8.9 \times 10^{-7}$ & $-1.4 \times 10^{1}$ & $0.0 \times 10^{0}$ & Robison et al,. 1982 \\
\hline Squash & \multicolumn{9}{|c|}{ Calculated using concentration ratio (Bq g ${ }^{-1}$ fruit wet weight versus $\mathrm{Bq} \mathrm{g}^{-1}$ soil dry weight) from Bikini Atoll.Robison unpublished data 1993} \\
\hline Pumpkin & \multicolumn{9}{|c|}{ Same as squash. } \\
\hline Banana & \multicolumn{9}{|c|}{ Same as papaya. } \\
\hline $\begin{array}{l}\text { Arrowroot } \\
\text { Citrus }\end{array}$ & \multicolumn{8}{|c|}{$\begin{array}{l}\text { Calculated using ratio ( } \mathrm{Bq} \mathrm{g}^{-1} \text { arrowroot wet weight versus } \mathrm{Bq} \mathrm{g}^{-1} \text { soil dry weight) from Rongelap Island. } \\
\text { Same as breadfruit. }\end{array}$} & Robison et al., 1994 \\
\hline Rainwater & - & 1 & $7.4 \times 10^{-9}$ & $7.4 \times 10^{-9}$ & $7.4 \times 10^{-9}$ & $7.4 \times 10^{-9}$ & $-1.9 \times 10^{1}$ & $0.0 \times 10^{0}$ & Noshkin et al., 1981b \\
\hline Well water & 1 & - & $<3.7 \times 10^{-10}$ & $<3.7 \times 10^{-10}$ & $<3.7 \times 10^{-10}$ & $<3.7 \times 10^{-10}$ & $0.0 \times 10^{0}<-2.2 \times 10^{1}$ & $0.0 \times 10^{0}$ & Noshkin et al., 1981b \\
\hline Malolo & \multicolumn{9}{|c|}{ Same as rainwater. } \\
\hline Coffee/Tea & \multicolumn{8}{|c|}{ Same as rainwater. } & \multirow{4}{*}{$\begin{array}{l}\text { This report } \\
1 \\
1\end{array}$} \\
\hline Soilg & \multicolumn{8}{|c|}{ Calculated using time distributions of $19 \mathrm{~h} \mathrm{~d}^{-1}$ in village area, $3 \mathrm{~h} \mathrm{~d}^{-1}$ in interior area and $2 \mathrm{~h} \mathrm{~d}^{-1}$ on the beach. } & \\
\hline Village $(0-5 \mathrm{~cm})$ & 7 & 4.5 & $\times 10^{-3}$ & $1.6 \times 10^{-2}$ & $7.6 \times 10^{-3}$ & $9.3 \times 10^{-3}$ & $4.0 \times 10^{-3} \quad-4.8 \times 10^{0}$ & $4.4 \times 10^{-1}$ & \\
\hline Interior $(0-5 \mathrm{~cm})$ & 88 & 2.8 & $\times 10^{-3}$ & $4.8 \times 10^{-2}$ & $1.3 \times 10^{-2}$ & $1.5 \times 10^{-2}$ & $8.2 \times 10^{-3} \quad-4.4 \times 10^{0}$ & $5.5 \times 10^{-1}$ & \\
\hline Beach $(0-5 \mathrm{~cm})$ & \multicolumn{9}{|c|}{ Calculated using ratio (whole island $\mathrm{Bq} \mathrm{g}^{-1}$ dry weight versus Beach $\mathrm{Bq} \mathrm{g}^{-1}$ dry weight) from ${ }^{137} \mathrm{Cs}_{\text {data taken in } 1993 .}$} \\
\hline \\
\hline \multicolumn{10}{|c|}{ b Number of specific activities where the reported values had acceptable counting errors according to Jennings and Mount 1983.} \\
\hline \multicolumn{10}{|c|}{ c Number of pooled samples from the same catch and species. Number of individual fish samples is 110.} \\
\hline \multicolumn{10}{|c|}{ d Since one less-than value was extremely high the median was used for dose assessment purposes. } \\
\hline \multicolumn{10}{|c|}{ e Data is used from Tridacna crocea and Hippopus hippopus. } \\
\hline \multicolumn{10}{|c|}{$\mathrm{f}$ Assumption is that the concentration ratios for ${ }^{239+240} \mathrm{Pu}$ and ${ }^{241} \mathrm{Am}$ are the same. } \\
\hline \multicolumn{10}{|c|}{ g Specific activity is based on determinations from samples taken from Utirik Island in 1993.} \\
\hline
\end{tabular}





\section{Appendix C}

Radionuclide Concentration in Vegetation, Utirik Atoll 
Appendix C-1. Radionuclide concentration summary for vegetation taken during the 1978 NMIRS and in 1994 on Bikrak Island (03I), Utirik Atoll.

\begin{tabular}{|c|c|c|c|c|c|c|c|c|}
\hline \multirow[b]{2}{*}{ Food Source } & \multirow[b]{2}{*}{$\mathbf{N}$} & \multicolumn{5}{|c|}{$\mathrm{Bq} \mathrm{g}^{-1}$ dry wt. } & \multirow{2}{*}{$\begin{array}{l}\text { Mean } \\
\text { of logs }\end{array}$} & \multirow{2}{*}{$\begin{array}{c}\text { SD } \\
\text { of logs }\end{array}$} \\
\hline & & Minimum & Maximum & Median & Mean & SD & & \\
\hline \multicolumn{9}{|c|}{${ }^{137} \mathrm{Cs}$} \\
\hline Dr. Coconut meat & 20 & $2.0 \times 10^{-3}$ & $1.6 \times 10^{-2}$ & $6.3 \times 10^{-3}$ & $7.2 \times 10^{-3}$ & $3.8 \times 10^{-3}$ & $-5.1 \times 10^{0}$ & $5.7 \times 10^{-1}$ \\
\hline Dr. Coconut juice & 18 & $7.8 \times 10^{-4}$ & $6.0 \times 10^{-3}$ & $2.6 \times 10^{-3}$ & $2.7 \times 10^{-3}$ & $1.5 \times 10^{-3}$ & $-6.1 \times 10^{0}$ & $6.3 \times 10^{-1}$ \\
\hline Copra meat & 6 & $2.7 \times 10^{-3}$ & $3.0 \times 10^{-2}$ & $1.3 \times 10^{-2}$ & $1.4 \times 10^{-2}$ & $9.0 \times 10^{-3}$ & $-4.5 \times 10^{0}$ & $8.0 \times 10^{-1}$ \\
\hline Copra juice & 6 & $1.9 \times 10^{-3}$ & $1.3 \times 10^{-2}$ & $4.8 \times 10^{-3}$ & $6.3 \times 10^{-3}$ & $4.8 \times 10^{-3}$ & $-5.4 \times 10^{0}$ & $8.4 \times 10^{-1}$ \\
\hline Pandanus & 15 & $6.8 \times 10^{-3}$ & $6.5 \times 10^{-2}$ & $2.5 \times 10^{-2}$ & $2.7 \times 10^{-2}$ & $1.6 \times 10^{-2}$ & $-3.8 \times 10^{0}$ & $7.0 \times 10^{-1}$ \\
\hline Breadfruit & 0 & - & - & - & - & - & - & - \\
\hline \multicolumn{9}{|c|}{${ }^{90} \mathrm{Sr}$} \\
\hline Dr. Coconut meat & 1 & $1.3 \times 10^{-4}$ & $1.3 \times 10^{-4}$ & $1.3 \times 10^{-4}$ & $1.3 \times 10^{-4}$ & $0.0 \times 10^{0}$ & $-9.0 \times 10^{0}$ & $0.0 \times 10^{0}$ \\
\hline Dr. Coconut juice & 2 & $3.4 \times 10^{-5}$ & $6.9 \times 10^{-5}$ & $5.2 \times 10^{-5}$ & $5.2 \times 10^{-5}$ & $2.4 \times 10^{-5}$ & $-9.9 \times 10^{0}$ & $4.9 \times 10^{-1}$ \\
\hline Copra meat & 2 & $5.5 \times 10^{-5}$ & $1.3 \times 10^{-4}$ & $9.2 \times 10^{-5}$ & $9.2 \times 10^{-5}$ & $5.3 \times 10^{-5}$ & $-9.4 \times 10^{0}$ & $6.0 \times 10^{-1}$ \\
\hline Copra juice & 3 & $3.8 \times 10^{-5}$ & $2.3 \times 10^{-4}$ & $5.0 \times 10^{-5}$ & $1.1 \times 10^{-4}$ & $1.1 \times 10^{-4}$ & $-9.5 \times 10^{0}$ & $9.7 \times 10^{-1}$ \\
\hline Pandanus & 9 & $3.9 \times 10^{-5}$ & $1.0 \times 10^{-2}$ & $3.2 \times 10^{-3}$ & $3.9 \times 10^{-3}$ & $4.2 \times 10^{-3}$ & $-6.8 \times 10^{0}$ & $2.2 \times 10^{0}$ \\
\hline Breadfruit & 0 & - & - & - & - & - & - & - \\
\hline \multicolumn{9}{|c|}{$239+240 \mathrm{Pu}$} \\
\hline Dr. Coconut meat ${ }^{\mathrm{a}}$ & 1 & $<5.8 \times 10^{-7}$ & $<5.8 \times 10^{-7}$ & $<5.8 \times 10^{-7}$ & $<5.8 \times 10^{-7}$ & $0.0 \times 10^{0}$ & $<-1.4 \times 10^{1}$ & $0.0 \times 10^{0}$ \\
\hline Dr. Coconut juice ${ }^{a}$ & 3 & $<-1.0 \times 10^{-6}$ & $<1.1 \times 10^{-6}$ & $<1.4 \times 10^{-7}$ & $<5.4 \times 10^{-8}$ & $<1.1 \times 10^{-6}$ & $<-1.4 \times 10^{1}$ & $<1.4 \times 10^{0}$ \\
\hline Copra meat ${ }^{\mathrm{a}}$ & 2 & $<-4.3 \times 10^{-7}$ & $<1.3 \times 10^{-6}$ & $<4.4 \times 10^{-7}$ & $<4.4 \times 10^{-7}$ & $<1.2 \times 10^{-6}$ & $<-1.4 \times 10^{1}$ & $0.0 \times 10^{0}$ \\
\hline Copra juice ${ }^{b}$ & 3 & $-1.4 \times 10^{-6}$ & $2.9 \times 10^{-6}$ & $9.1 \times 10^{-7}$ & $7.9 \times 10^{-7}$ & $2.2 \times 10^{-6}$ & $-1.3 \times 10^{1}$ & $8.2 \times 10^{-1}$ \\
\hline Pandanus ${ }^{\mathrm{C}}$ & 10 & $2.2 \times 10^{-7}$ & $9.7 \times 10^{-6}$ & $7.9 \times 10^{-7}$ & $1.8 \times 10^{-6}$ & $2.9 \times 10^{-6}$ & $-1.4 \times 10^{1}$ & $1.1 \times 10^{0}$ \\
\hline Breadfruit & 0 & - & - & - & - & - & - & - \\
\hline \multicolumn{9}{|c|}{${ }^{241} \mathrm{Am}$} \\
\hline Dr. Coconut meat & 0 & - & - & - & - & - & - & - \\
\hline Dr. Coconut juice & 3 & $3.2 \times 10^{-6}$ & $8.5 \times 10^{-6}$ & $3.4 \times 10^{-6}$ & $5.0 \times 10^{-6}$ & $3.0 \times 10^{-6}$ & $-1.2 \times 10^{1}$ & $5.4 \times 10^{-1}$ \\
\hline Copra meat & 0 & - & - & - & - & - & - & - \\
\hline Copra juice & 3 & $2.1 \times 10^{-6}$ & $5.2 \times 10^{-6}$ & $2.4 \times 10^{-6}$ & $3.2 \times 10^{-6}$ & $1.7 \times 10^{-6}$ & $-1.3 \times 10^{1}$ & $5.0 \times 10^{-1}$ \\
\hline Pandanus & 9 & $3.1 \times 10^{-7}$ & $6.6 \times 10^{-6}$ & $2.8 \times 10^{-6}$ & $3.1 \times 10^{-6}$ & $2.3 \times 10^{-6}$ & $-1.3 \times 10^{1}$ & $1.1 \times 10^{0}$ \\
\hline Breadfruit & 0 & - & - & - & - & - & - & - \\
\hline
\end{tabular}

NOTE: Specific Activity is decay corrected to 1998. N = the number of composite samples.

a Reported values were either negative or had a greater than $100 \%$ uncertainty at $1 \mathrm{~s}$.

$\mathrm{b}$ One of the reported values was negative.

c Three of the reported values had a greater than $100 \%$ uncertainty at $1 \mathrm{~s}$. 
Appendix C-2. Radionuclide concentration summary for vegetation taken during the 1978 NMIRS and in 1994 on Aon Island (08I), Utirik Atoll.

\begin{tabular}{|c|c|c|c|c|c|c|c|c|}
\hline \multirow[b]{2}{*}{ Food Source } & \multirow[b]{2}{*}{$\mathbf{N}$} & \multicolumn{5}{|c|}{$\mathrm{Bq} \mathrm{g}^{-1}$ dry wt. } & \multirow{2}{*}{$\begin{array}{l}\text { Mean } \\
\text { of logs }\end{array}$} & \multirow{2}{*}{$\begin{array}{c}\text { SD } \\
\text { of logs }\end{array}$} \\
\hline & & Minimum & Maximum & Median & Mean & SD & & \\
\hline \multicolumn{9}{|c|}{${ }^{137} \mathrm{Cs}$} \\
\hline Dr. Coconut meat & 63 & $3.1 \times 10^{-3}$ & $1.3 \times 10^{-1}$ & $1.8 \times 10^{-2}$ & $2.3 \times 10^{-2}$ & $2.1 \times 10^{-2}$ & $-4.1 \times 10^{0}$ & $8.4 \times 10^{-1}$ \\
\hline Dr. Coconut juice & 57 & $6.8 \times 10^{-4}$ & $3.8 \times 10^{-2}$ & $7.4 \times 10^{-3}$ & $1.1 \times 10^{-2}$ & $9.3 \times 10^{-3}$ & $-4.9 \times 10^{0}$ & $9.4 \times 10^{-1}$ \\
\hline Copra meat & 7 & $2.7 \times 10^{-3}$ & $7.7 \times 10^{-2}$ & $5.6 \times 10^{-2}$ & $5.0 \times 10^{-2}$ & $2.5 \times 10^{-2}$ & $-3.3 \times 10^{0}$ & $1.2 \times 10^{0}$ \\
\hline Copra juice & 8 & $4.4 \times 10^{-3}$ & $5.5 \times 10^{-2}$ & $1.2 \times 10^{-2}$ & $1.7 \times 10^{-2}$ & $1.7 \times 10^{-2}$ & $-4.4 \times 10^{0}$ & $8.9 \times 10^{-1}$ \\
\hline Pandanus & 8 & $4.1 \times 10^{-3}$ & $1.0 \times 10^{-1}$ & $3.0 \times 10^{-2}$ & $3.8 \times 10^{-2}$ & $3.6 \times 10^{-2}$ & $-3.8 \times 10^{0}$ & $1.2 \times 10^{0}$ \\
\hline Breadfruit & 3 & $1.1 \times 10^{-2}$ & $2.1 \times 10^{-2}$ & $1.4 \times 10^{-2}$ & $1.6 \times 10^{-2}$ & $5.3 \times 10^{-3}$ & $-4.2 \times 10^{0}$ & $3.3 \times 10^{-1}$ \\
\hline Arrowroot & 1 & $7.6 \times 10^{-3}$ & $7.6 \times 10^{-3}$ & $7.6 \times 10^{-3}$ & $7.6 \times 10^{-3}$ & $0.0 \times 10^{0}$ & $-4.9 \times 10^{0}$ & $0.0 \times 10^{0}$ \\
\hline \multicolumn{9}{|c|}{${ }^{90} \mathrm{Sr}$} \\
\hline Dr. Coconut meat & 1 & $2.1 \times 10^{-4}$ & $2.1 \times 10^{-4}$ & $2.1 \times 10^{-4}$ & $2.1 \times 10^{-4}$ & $0.0 \times 10^{0}$ & $-8.5 \times 10^{0}$ & $0.0 \times 10^{0}$ \\
\hline Dr. Coconut juice & 4 & $8.1 \times 10^{-5}$ & $1.5 \times 10^{-4}$ & $1.3 \times 10^{-4}$ & $1.2 \times 10^{-4}$ & $3.2 \times 10^{-5}$ & $-9.0 \times 10^{0}$ & $2.9 \times 10^{-1}$ \\
\hline Copra meat & 4 & $6.5 \times 10^{-5}$ & $2.5 \times 10^{-4}$ & $1.8 \times 10^{-4}$ & $1.7 \times 10^{-4}$ & $7.8 \times 10^{-5}$ & $-8.8 \times 10^{0}$ & $5.9 \times 10^{-1}$ \\
\hline Copra juice & 3 & $1.1 \times 10^{-4}$ & $3.3 \times 10^{-4}$ & $2.7 \times 10^{-4}$ & $2.4 \times 10^{-4}$ & $1.2 \times 10^{-4}$ & $-8.5 \times 10^{0}$ & $6.1 \times 10^{-1}$ \\
\hline Pandanus & 4 & $2.0 \times 10^{-5}$ & $3.7 \times 10^{-3}$ & $1.8 \times 10^{-3}$ & $1.8 \times 10^{-3}$ & $1.8 \times 10^{-3}$ & $-7.5 \times 10^{0}$ & $2.4 \times 10^{0}$ \\
\hline Breadfruit & \multicolumn{8}{|c|}{$239+240 \mathrm{Pu}$} \\
\hline Dr. Coconut meat ${ }^{\mathrm{a}}$ & 1 & $<-9.1 \times 10^{-7}$ & $<-9.1 \times 10^{-7}$ & $<-9.1 \times 10^{-7}$ & $<-9.1 \times 10^{-7}$ & $0.0 \times 10^{0}$ & $0.0 \times 10^{0}$ & $0.0 \times 10^{0}$ \\
\hline Dr. Coconut juice ${ }^{a}$ & 4 & $<-8.5 \times 10^{-7}$ & $<2.4 \times 10^{-6}$ & $<2.1 \times 10^{-7}$ & $<4.9 \times 10^{-7}$ & $<1.5 \times 10^{-6}$ & $<-1.3 \times 10^{1}$ & $<6.8 \times 10^{-1}$ \\
\hline Copra meat ${ }^{\mathrm{a}}$ & 4 & $<-2.2 \times 10^{-6}$ & $<3.2 \times 10^{-6}$ & $<-3.5 \times 10^{-7}$ & $<8.1 \times 10^{-8}$ & $<2.4 \times 10^{-6}$ & $<-1.4 \times 10^{1}$ & $<1.0 \times 10^{0}$ \\
\hline Copra juice ${ }^{b}$ & 6 & $<-1.6 \times 10^{-6}$ & $3.7 \times 10^{-5}$ & $<7.1 \times 10^{-7}$ & $<1.0 \times 10^{-5}$ & $<1.6 \times 10^{-5}$ & $<-1.1 \times 10^{1}$ & $<1.1 \times 10^{0}$ \\
\hline Pandanus ${ }^{\mathrm{C}}$ & 4 & $1.1 \times 10^{-7}$ & $8.8 \times 10^{-7}$ & $5.7 \times 10^{-7}$ & $5.3 \times 10^{-7}$ & $3.6 \times 10^{-7}$ & $-1.5 \times 10^{1}$ & $9.6 \times 10^{-1}$ \\
\hline Breadfruit & 1 & $1.9 \times 10^{-6}$ & $1.9 \times 10^{-6}$ & $\begin{array}{c}1.9 \times 10^{-6} \\
{ }^{241} \mathbf{A m}\end{array}$ & $1.9 \times 10^{-6}$ & $0.0 \times 10^{0}$ & $-1.3 \times 10^{1}$ & $0.0 \times 10^{0}$ \\
\hline Dr. Coconut meat ${ }^{\mathrm{a}}$ & 1 & $<-1.0 \times 10^{-6}$ & $<-1.0 \times 10^{-6}$ & $<-1.0 \times 10^{-6}$ & $<-1.0 \times 10^{-6}$ & $0.0 \times 10^{0}$ & $0.0 \times 10^{0}$ & $0.0 \times 10^{0}$ \\
\hline Dr. Coconut juice & 4 & $2.0 \times 10^{-6}$ & $5.6 \times 10^{-6}$ & $3.5 \times 10^{-6}$ & $4.1 \times 10^{-6}$ & $1.8 \times 10^{-6}$ & $-1.3 \times 10^{1}$ & $5.1 \times 10^{-1}$ \\
\hline Copra meat ${ }^{a}$ & 1 & $<1.1 \times 10^{-6}$ & $<1.1 \times 10^{-6}$ & $<1.1 \times 10^{-6}$ & $<1.1 \times 10^{-6}$ & $0.0 \times 10^{0}$ & $<-1.4 \times 10^{1}$ & $0.0 \times 10^{0}$ \\
\hline Copra juice ${ }^{\mathrm{d}}$ & 6 & $-3.3 \times 10^{-6}$ & $6.1 \times 10^{-5}$ & $1.8 \times 10^{-5}$ & $2.6 \times 10^{-5}$ & $2.3 \times 10^{-5}$ & $-1.1 \times 10^{1}$ & $1.0 \times 10^{0}$ \\
\hline Pandanus ${ }^{\mathrm{C}}$ & 3 & $2.3 \times 10^{-7}$ & $1.6 \times 10^{-6}$ & $8.3 \times 10^{-7}$ & $1.4 \times 10^{-6}$ & $1.6 \times 10^{-6}$ & $-1.4 \times 10^{1}$ & $1.3 \times 10^{0}$ \\
\hline Breadfruit & 0 & - & - & - & - & - & - & \\
\hline
\end{tabular}

NOTE: Specific Activity is decay corrected to 1998. $\mathrm{N}=$ the number or composite samples.

a Reported valves were either negative or had a greater than $100 \%$ uncertainty at $1 \mathrm{~s}$.

${ }^{b}$ Four of the reported values were either negative or had a greater than $100 \%$ uncertainty at $1 \mathrm{~s}$.

c One of the reported values had a greater than $100 \%$ uncertainty at 1 s.

$\mathrm{d}$ One of the reported values was negative. 
Appendix C-3. Radionuclide concentration summary for vegetation taken in 1994 on Elluk Island (02I), Utirik Atoll.

\begin{tabular}{|c|c|c|c|c|c|c|c|c|}
\hline \multirow[b]{2}{*}{ Food Source } & \multirow[b]{2}{*}{$\mathbf{N}$} & \multicolumn{5}{|c|}{ Bq $\mathrm{g}^{-1}$ dry wt. } & \multirow{2}{*}{$\begin{array}{l}\text { Mean } \\
\text { of logs }\end{array}$} & \multirow{2}{*}{$\begin{array}{l}\text { SD } \\
\text { of logs }\end{array}$} \\
\hline & & Minimum & Maximum & Median & Mean & SD & & \\
\hline \multicolumn{9}{|c|}{${ }^{137} \mathrm{Cs}$} \\
\hline Dr. Cocc & 4 & $2.4 \times 10^{-3}$ & $8.0 \times 10^{-3}$ & $4.9 \times 10^{-3}$ & $5.1 \times 10^{-3}$ & $2.3 \times 10^{-3}$ & $-5.4 \times 10^{0}$ & $4.9 \times 10^{-1}$ \\
\hline Dr. Coconut juice & 3 & $5.4 \times 10^{-4}$ & $1.9 \times 10^{-3}$ & $1.4 \times 10^{-3}$ & $1.3 \times 10^{-3}$ & $7.0 \times 10^{-4}$ & $-6.8 \times 10^{0}$ & $6.6 \times 10^{-1}$ \\
\hline Copra meat & 1 & $3.5 \times 10^{-3}$ & $3.5 \times 10^{-3}$ & $3.5 \times 10^{-3}$ & $3.5 \times 10^{-3}$ & $0.0 \times 10^{0}$ & $-5.7 \times 10^{0}$ & $0.0 \times 10^{0}$ \\
\hline Copra juice & 1 & $3.6 \times 10^{-3}$ & $3.6 \times 10^{-3}$ & $3.6 \times 10^{-3}$ & $3.6 \times 10^{-3}$ & $0.0 \times 10^{0}$ & $-5.6 \times 10^{0}$ & $0.0 \times 10^{0}$ \\
\hline Pandanus & 2 & $8.0 \times 10^{-3}$ & $1.0 \times 10^{-2}$ & $9.0 \times 10^{-3}$ & $9.0 \times 10^{-3}$ & $1.5 \times 10^{-3}$ & $-4.7 \times 10^{0}$ & $1.7 \times 10^{-1}$ \\
\hline Breadfruit & 0 & - & - & - & - & - & - & - \\
\hline
\end{tabular}

NOTE: Specific Activity is decay corrected to 1998.

$\mathrm{N}=$ the number of composite samples. 
Appendix D

The Activity Intake in $\mathrm{Bq} \mathrm{d}^{-1}$ for Each Food Product for ${ }^{137} \mathrm{Cs}$, 90Sr, 239+240 Pu and 241 Am. Utirik Atoll 
Appendi $\times$ D-1. The daily intake in $\mathrm{Bq}^{-1}$ decayed to 1998 from the diet models for IA and IUA.

Imported Foods Available

Imported Foods Unavailable

\begin{tabular}{|c|c|c|c|c|c|c|c|c|}
\hline \multirow[b]{2}{*}{ Local Food } & \multicolumn{4}{|c|}{$\mathrm{Bq} \mathrm{d}^{-1}$} & \multicolumn{4}{|c|}{$\mathrm{Bq} \mathrm{d}^{-1}$} \\
\hline & ${ }^{137} \mathrm{Cs}$ & ${ }^{90} \mathrm{Sr}$ & $\mathbf{u}$ & ${ }^{11} \mathrm{Am}$ & ${ }^{37} \mathrm{Cs}$ & ${ }^{90} \mathrm{Sr}$ & $\mathbf{u}$ & ${ }^{241} \mathrm{Am}$ \\
\hline the & $1 \times 10$ & $7 \times 10^{-4}$ & & & $\times 10^{-2}$ & $5 \times 10^{-4}$ & & \\
\hline una & $7 \times 1$ & $3 \times 10^{-4}$ & & & & & & \\
\hline Tahi & $7 \times 10^{-3}$ & $3 \times 10^{-5}$ & 7.3 & -7 & $5 \times$ & & & \\
\hline $\operatorname{Iar}$ & & $5.1 \times 10^{-5}$ & & & & & & \\
\hline & & $1.2 \times 10^{-4}$ & & $5.7 \times 10^{-6}$ & & $7.6 \times 10^{-4}$ & & \\
\hline dints & $1 \times 10^{-5}$ & $2.7 \times 10^{-4}$ & & & & $2.4 \times 10^{-3}$ & & \\
\hline ochus & ( & & & & & & & \\
\hline e & $3.0 \times$ & $10^{-5}$ & 2.7 & -6 & & $4.8 \times 10^{-4}$ & & \\
\hline drul & $5.5 \times 10^{-5}$ & $1.8 \times 10^{-4}$ & $5.0 \times$ & $2 \times$ & $2.5 \times 10^{-4}$ & $8.1 \times 10^{-4}$ & & $4 \times 10^{-5}$ \\
\hline ocont & $1.3 \times 1$ & $1.3 \times 10^{-2}$ & $1.9 \times$ & & $7.7 \times 10^{-1}$ & $7.5 \times 10^{-2}$ & & \\
\hline and & $1.0 \mathrm{n}$ & $0.0 \times$ & & $0>$ & & & & \\
\hline cto & & $0^{-5}$ & 1 & & -3 & $0^{-4}$ & & \\
\hline ur & & & & & & & & \\
\hline lo & & & & & & & & \\
\hline & $3.4 \times$ & & & & & & & $10^{-4}$ \\
\hline & $1.1 \times$ & 8.1 & & & & & & \\
\hline & $4.4 \times$ & -5 & & & & & & \\
\hline & 15 & 0.0 & & s. & & & & \\
\hline & & -5 & & & -1 & $\gamma^{-4}$ & & $0^{-5}$ \\
\hline Pork h & & & & & & & & \\
\hline ir & & -5 & & & & & & $0^{-6}$ \\
\hline ird & 1 & 37 & & & & & & $10^{-6}$ \\
\hline & 9. & $0^{-3}$ & & & & & & $10^{-5}$ \\
\hline & $2.6 \times$ & $1.4>$ & 3.4 & -6 & & $0^{-3}$ & & $10^{-5}$ \\
\hline ano & $3.9 \times$ & $1.9 \times 10^{-2}$ & $1.8 \times$ & $2.7>$ & $0^{0}$ & $10^{-2}$ & & $10^{-4}$ \\
\hline Pand & $2.2 \times$ & $1.1 \times 10^{-3}$ & & & & $3.1 \times 10^{-3}$ & & \\
\hline Bre & & & & & & & & \\
\hline ocon & & & & & & & & $10^{-4}$ \\
\hline & & & & & & & & $10^{-4}$ \\
\hline & 1 & & & & & & & $10^{0}$ \\
\hline$t$ & $5.3 \times 1$ & $2.2>$ & 7.1 & $1.1\rangle$ & $2.2 \times 10^{0}$ & $\times 10^{-3}$ & 2.9 & $4.4 \times 10^{-4}$ \\
\hline & $3.4 \times 10^{-1}$ & $8.4 \times 10^{-4}$ & $2.7 \times 10^{-5}$ & $4.1 \times$ & $1.4 \times 10^{0}$ & $3.6 \times 10^{-3}$ & $1.1 \times$ & $1.7 \times 10^{-4}$ \\
\hline pr & $2.2 \times 1$ & $5.4 \times 10^{-4}$ & $1.7 \times 10^{-5}$ & & $2.4 \times 10^{0}$ & $6.1 \times 10^{-3}$ & & $3.0 \times 10^{-4}$ \\
\hline Mars & & & & & & & & \\
\hline$a^{a}$ & & & 1.5 & & $0^{0}$ & $0^{-3}$ & & \\
\hline & 0 & 0.0 & 0.0 & 0.0 & $0^{0}$ & $10^{0}$ & 0.0 & $10^{0}$ \\
\hline & 1 & $10^{-4}$ & $2.3 \times 10^{-7}$ & $1.4 \times 10^{-7}$ & $4.1 \times 10^{-2}$ & $2.4 \times 10^{-3}$ & $7.2 \times 10^{-7}$ & $4.5 \times 10^{-7}$ \\
\hline Banana & $1.5 \times 10^{-4}$ & $3.7 \times 10^{-6}$ & $1.0 \times 10^{-8}$ & $1.8 \times 10^{-8}$ & $3.1 \times 10^{-3}$ & $7.7 \times 10^{-5}$ & $2.2 \times 10^{-7}$ & $3.7 \times 10^{-7}$ \\
\hline Arrowr & $7.3 \times 10^{-3}$ & $1.2 \times 10^{-3}$ & $1.4 \times 10^{-5}$ & $3.1 \times 10^{-6}$ & $1.3 \times 10^{-1}$ & $2.1 \times 10^{-2}$ & $2.4 \times 10^{-4}$ & $5.4 \times 10^{-5}$ \\
\hline it & $1.8 \times$ & $4.2>$ & $5.5 \times$ & $7.3 \times$ & & & & $1.0 \times 10^{-7}$ \\
\hline $\mathrm{Rai}$ & 1.0 & & & & & & & \\
\hline Well & $1.4 \times 10^{-2}$ & $4.0>$ & $1.5 \times 10^{-6}$ & $7.6 \times 10^{-8}$ & $2.1 \times 10^{-2}$ & $5.9 \times 10^{-4}$ & $2.3 \times 10^{-6}$ & $10^{-7}$ \\
\hline Ialolo & $6.7 \times 10^{-4}$ & $4.5 \times 10^{-4}$ & $3.7 \times 10^{-6}$ & $1.5 \times 10^{-6}$ & $0.0 \times 10^{0}$ & $0.0 \times 10^{0}$ & $0.0 \times 10^{0}$ & $0.0 \times 10^{0}$ \\
\hline offee/7 & $7.6 \times 10^{-4}$ & $5.2 \times 10^{-4}$ & $4.2 \times 10^{-6}$ & $1.7 \times 10^{-6}$ & $0.0 \times 10^{0}$ & $0.0 \times 10^{0}$ & $0.0 \times 10^{0}$ & $0.0 \times 10^{0}$ \\
\hline & $3.7 \times 10$ & $1.9 \times 10^{-3}$ & & & $3.7 \times 10^{-3}$ & $1.9 \times 10^{-3}$ & $1.0 \times 10^{-3}$ & $9.2 \times 10^{-4}$ \\
\hline lotal local & 5.9 & 0.087 & 0.0020 & 0.0018 & 19 & 0.37 & 0.0063 & 0.0040 \\
\hline
\end{tabular}

